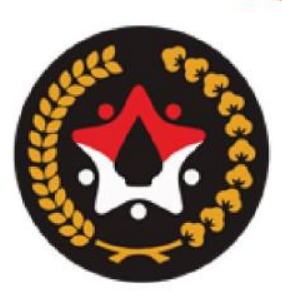

KEMENTERIAN KOORDINATOR

BIDANG PEMBANGUNAN MANUSIA DAN KEBUDAYAAN

REPUBLIK INDONESIA

\title{
RESTORASI SOSIAL Untuk Indonesia Maju dan Bermartabat
}

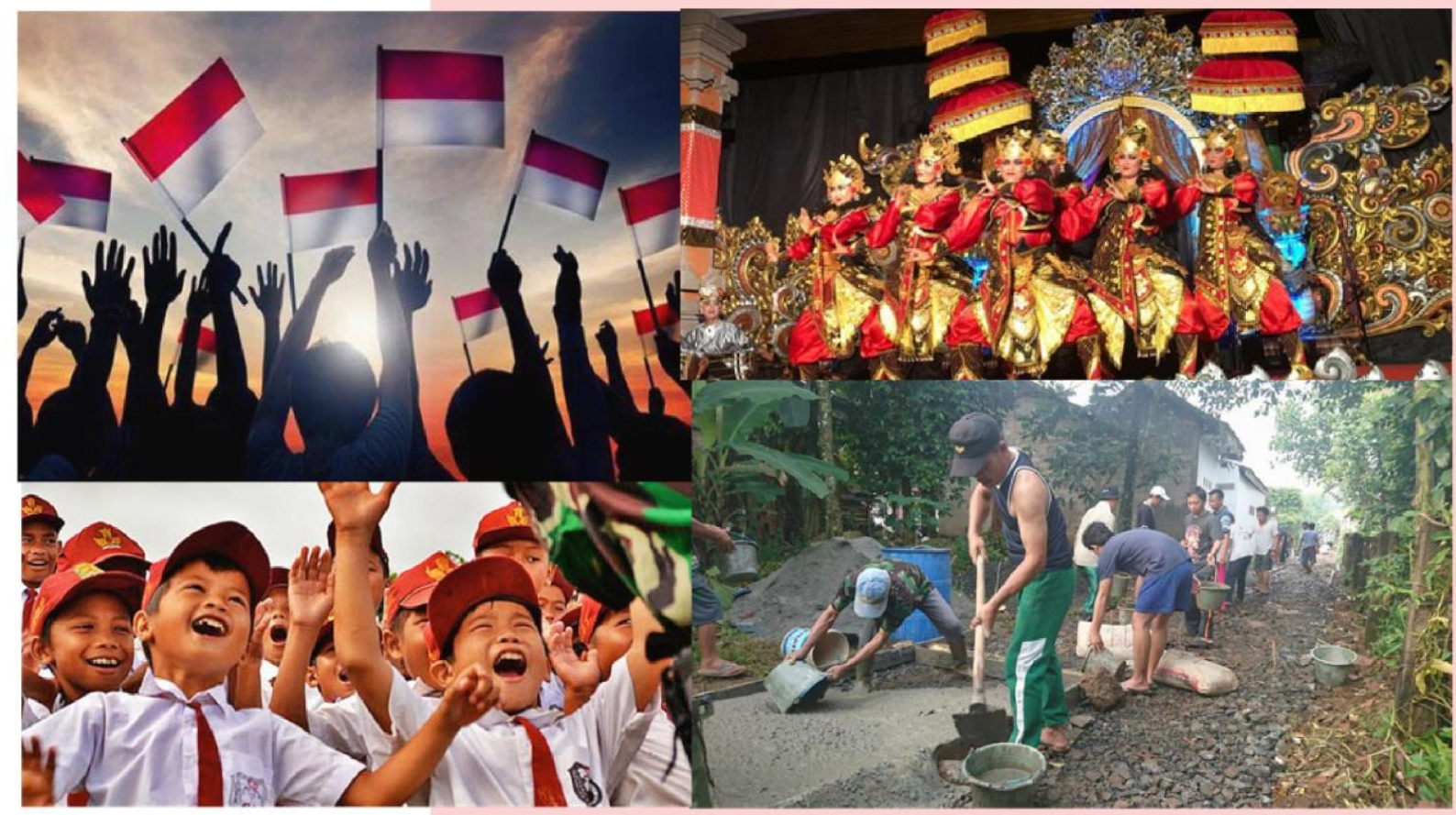

\section{Haswan Yunaz}




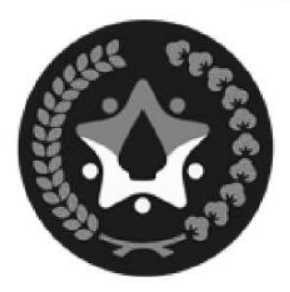

KEMENTERIAN KOORDINATOR

BIDANG PEMBANGUNAN MANUSIA DAN KEBUDAYAAN

REPUBLIK INDONESIA

\section{RESTORASI SOSIAL Untuk Indonesia Maju dan Bermartabat}

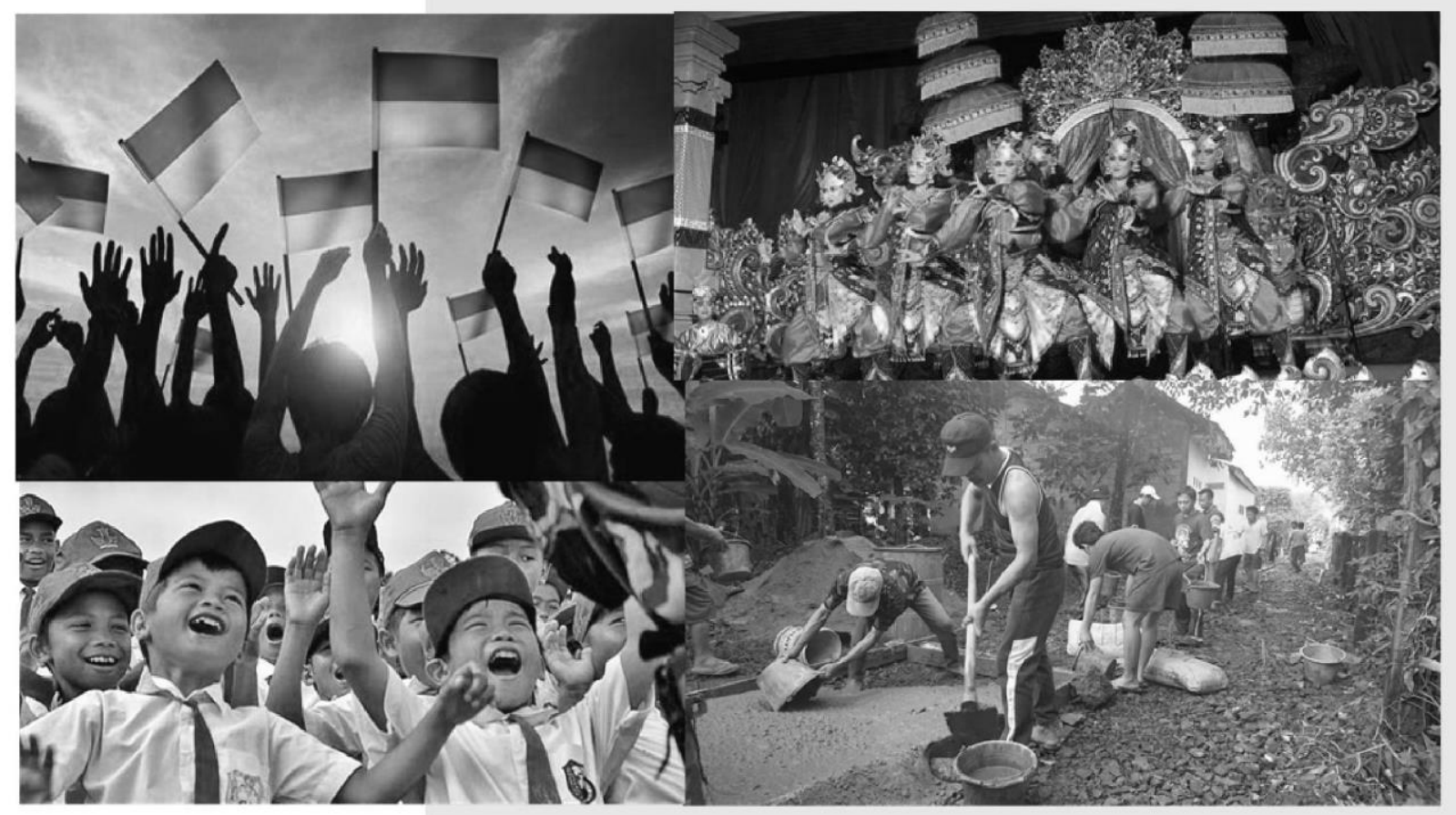

\section{Haswan Yunaz}




\section{Restorasi Sosial}

\section{Untuk Indonesia Maju dan Bermartabat}

Penulis: Haswan Yunaz

Design dan tata letak: Dwi Tyas Wijayanti

Hak Cipta dilindungi Undang Undang

Diterbitkan pertama kali oleh Kemenko PMK

ISBN 978-602-408-021-1

Dilarang keras menterjemahkan, memfotocopi atau memperbanyak sebagian atau seluruh isi buku ini tanpa ijin tertulis dari penulis

Dicetak pertama kali oleh Kemenko PMK tahun 2018

Isi diluar tanggung jawab percetakan 

Assalamu'alaikum Wr. Wb.

Puji dan syukur kami panjatkan kehadirat ALLAH SWT dengan rahmat dan hidayah-NYA, kami dapat menyusun buku yang berjudul Restorasi Sosial Untuk Indonesia Maju dan Bermartabat. Buku ini merupakan hasil kajian Staf Ahli Menteri Koordinator Pembangunan Manusia dan Kebudayaan Bidang Multikulturalisme, Restorasi Sosial dan Jati Diri Bangsa pada Tahun 2018.

Bersamaan dengan kemajuan zaman, muncul berbagai masalah social yang perlu penanganan lebih lanjut, seperti pudarnya semangat persatuan dan kesatuan, intoleransi, individualisme, saling menebar hoax, fitnah, turunnya semangat gotong royong dan sebagainya. Untuk itulah diperlukannya penguatan kembali semangat berbangsa dan bernegara, membangun solidaritas sosial guna memperteguh kebhinnekaan dan memperkuat restorasi sosial Indonesia. Berbagai cara dapat dilakukan guna mengembalikan kebhinnekaan Indonesia melalui kebijakan antara lain memperkuat pendidikan karakter dan menciptakan ruangruang dialog antarwarga, bergotong royong dan saling memberi serta membantu antar sesama warga bangsa. Oleh karena itu, melalui penulisan buku Restorasi Sosial ini diharapkan dapat menjadi sebuah pemikiran guna memperkokoh kembali rasa kebersamaan sebagai bangsa yang berdaulat secara politik, berdikari secara ekonomi dan berkepribadian dalam kebudayaan.

Kami menyadari buku ini masih jauh dari sempurna dan disana sini terdapat kekurangan, untuk itu saran dan pendapat kami harapkan dari para pembaca yang budiman. Akhir kata kami mengucapkan terima kasih kepada semua pihak yang telah membantu baik secara langsung maupun tidak langsung sehingga tersusunnya buku ini. Semoga ALLAH SWT senantiasa meridhoi 
keberagaman bangsa Indonesia menjadi satu kekuatan menuju masyarakat yang adil dan makmur.

Wassalamu'alaikum Wr. Wb.

Jakarta, 3 Desember 2018

Haswan Yunaz 


\section{Agama:}

Agama merupakan pedoman hidup untuk meraih kebahagiaan disunia dan diakhirat. Sebagai umat beragama, seseorang harus menjalankan kewajiban dan menjauhi larangan Tuhan.

\section{Akulturasi:}

Akulturasi adalah peleburan dua unsur kebudayaan yang berbeda tanpa menghilangkan ciri khas kebudayaan masingmasing.

\section{Disintegrasi:}

Disintegrasi adalah suatu keadaan dimana tidak ada keserasian pada bagian-bagian dari suatu kebulatan yang dikarenakan adanya pertentangan-pertentangan. Disintegrasi dapat dirumuskan sebagai suatu proses berpudarnya norma-norma dan nilai-niai dalam masyarakat karena peubahanperubahan yang terjadi pada lembaga-lembaga

kemasyarakatan.

\section{Individu:}

Individu adalah orang, seorang, pribadi atau perseorangan.

\section{Integrasi:}

Integrasi (integration) adalah suatu proses pengembangan masyarakat dimana segenap kelompok ras dan etnik mampu berperan serta secara bersamasama dalam kehidupan budaya dan ekonomi.

\section{Interaksi Sosial:}

Interaksi adalah suatu hubungan timbal balik untuk mancapai suatu keinginan, tujuan maupun penyampaian maksud untuk hidup bersama dengan manusia lainnya dalam memenuhi kebutuhan hidupnya.

\section{Kelompok Sosial:}

Salah satu penggunaan istilah mengartikan kelompok sebagai setiap kumpulan manusia 
secara fisik yang tidak memiliki ikatan kebersamaan apa-apa, kecuali jarak fisik yang dekat. Pengertian yang kedua adalah sejumlah orang yang memiliki persamaan ciri-ciri tertentu. Pnggunaan lainnya mendefinisikan kelompok sebagai sejumlah orang yang memiliki pola interaksi yang terorganisasi dan terjadi secaraberulang-ulang.

\section{Komunikasi:}

Komunikasi adalah suatu proses dalam mana seseorang atau beberapa orang, kelompok, organisasi, dan masyarakat menciptakan, dan menggunakan informasi agar terhubung dengan lingkungan dan orang lain.

\section{Konflik:}

Konflik sosial adalah suatu keadaan masyarakat yang mengalami suatu pertikaian antara anggotanya yang mengakibatkan terancamnya keutuhan masyarakat tersebut yang dilator belakangi dengan perbedaan kepentingan antar anggota.

\section{Kontak Sosial:}

Interaksi sosial merupakan suatu fondasi dari hubungan yang berupa tindakan yang berdasarkan norma dan nilai sosial yang berlaku dan diterapkan di dalam masyarakat. Kontak sosial merupakan awal terjadinya interaksi sosial baik dilakukan secara langsung ataupun tidak.

\section{Lingkungan:}

Lingkungan adalah daerah (kawasan dan sebagainya) yg termasuk di dalamnya; bagian wilayah dl kelurahan yg merupakan lingkungan kerja pelaksanaan pemerintahan desa.

\section{Nilai:}

Nilai adalah gagasan mengenai apakah pengalaman berarti atau tidak berarti. Nilai mengarahkan perilaku dan pertimbangan seseorang.

\section{Norma:}

Norma (norm) adalah standar perilaku. 


\section{Organisasi:}

Organisasi merupakan artikulasi dari bagian-bagian yang merupakan suatu kesatuan fungsional. Yang mana bagian-bagian yang dimakasud adalah kumpulan dari beberapa anggota yang membentuk suatu komunitas.

\section{Pengendalian Sosial:}

Pengendalian sosial (sosial control) adalah segenap cara dan proses yang digunakan oleh suatu kelompok atau masyarakat untuk menjamin terciptanya konformitas para anggotanya terhadap harapan kelompok atau masyarakat itu.

\section{Penyimpangan Sosial:}

Penyimpangan adalah setiap perilaku yang dinyatakan sebagai suatu pelanggaran terhadap norma-norma keelompok atau masyarakat.

\section{Perubahan Sosial:}

Perubahan Sosial (sosial change) adalah Perubahan dalam struktur sosial dan jalinan hubungan dalam masyarakat; seringkali penggunaannya dipertukarkan dengan istilah perubahan budaya.

\section{Proses Sosial:}

Proses Sosial adalah cara berhubungan yang dapat dilihat apabila individu dan kelompok saling bertemu dan menentukan sistem serta bentuk hubungan tersebut atau apa yang akan terjadi apabila ada perubahan-perubahan yang menyebabkan goyahnya cara-cara hidup yang telah ada. Atau dengan kata lain, proses sosial diartikan sebagai pengaruh timbal balik antara berbagai segi kehidupan bersama.

\section{Strata Sosial:}

Strata Sosial adalah menurut Drs. Robert M.Z. Lawang adalah penggolongan orang-orang yang termasuk dalam suatu sistem sosial tertentu ke dalam lapisan-lapisan hirarkis menurut dimensi kekuasaan, privilese dan prestise.

\section{Sistem Sosial:}

Sistem Sosial dapat diartikan sebagai suatu keseluruhan dari unsur-unsur sosial yang 
berkaitan dan berhubungan satu sama lain serta saling mempengaruhi dalam suatu kesatuan atau kebulatan.

\section{Wewenang:}

Wewenang adalah kekuasaan yang ada pada seseorang atau sekelompok orang, yang mempunyai dukungan atau mendapat pengakuan dari masyarakat. 


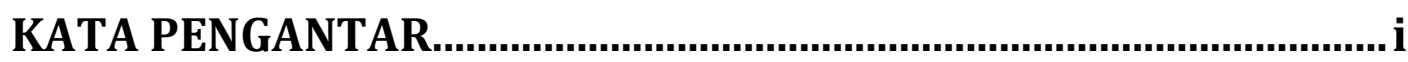

GLOSARIUM ...................................................................................... ii

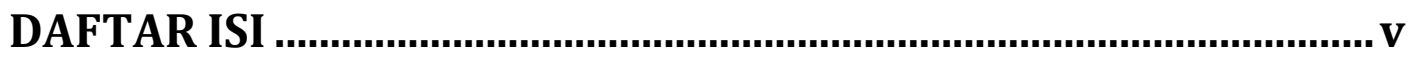

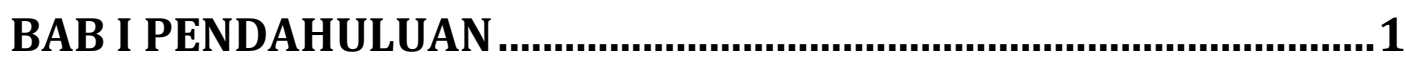

A. Definisi Restorasi Sosial ..........................................................................

B. Tujuan Restorasi Sosial..........................................................................

C. Sifat yang terdapat pada Restorasi Sosial .........................................6

D. Sebab Terjadinya Restorasi Sosial......................................................

E. Hal yang Memperkuat dan Mengancam Restorasi Sosial ........7

\section{BAB II BEBERAPA KONSEP \& TEORI RESTORASI}

SOSIAL 11

A. Landasan Operasional Restorasi Sosial .........................................12

B. Restorasi Sosial dalam Pandangan Agama Islam .........................12

1. Konsep Sosial dalam Islam Dari Sudut Pandang

Surat Ali-Imran Ayat 133-134 ...................................................13

2. Definisi Ilmu Sosial Profetik (ISP).............................................16

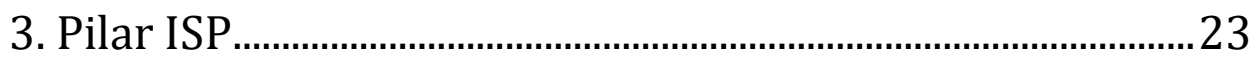

C. Paradigma dalam Ilmu Sosial............................................................28

1. Ilmu Sosial Posivistik .....................................................................30

2. Ilmu Sosial Kontruktivisme............................................................

3. Ilmu Sosial Kritis ............................................................................

D. Teori-Teori Sosial dalam Sosiologi....................................................40

1. Teori Konflik.................................................................................... 40

2. Teori Fungsional - Struktural ......................................................42

3. Teori Interaksi Simbolik ..........................................................46 
4. Teori Pertukaran Sosial (Sosial Exchange

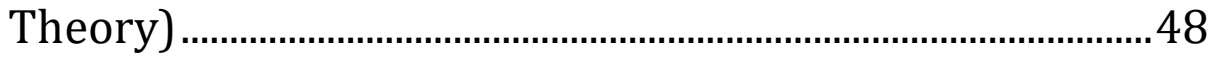

BAB III MASALAH \& KONFLIK SOSIAL ......................................... 49

A. Masalah Sosial ....................................................................................50

B. Pengertian Konflik Sosial .................................................................51

C. Faktor Penyebab Konflik Sosial ......................................................55

D. Permasalahan Baru di Era Globalisasi ..............................................60

BAB IV PELAKSANAAN PENGUATAN RESTORASI

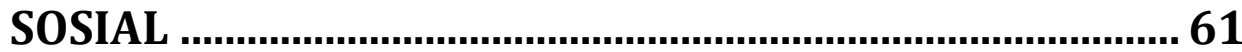

A. Sasaran Penguatan Restorasi Sosial .................................................62

B. Strategi Penguatan Restorasi Sosial ...............................................70

C. Pelaksanaan Penguatan Restorasi Sosial ......................................76

BAB V RESTORASI SOSIAL DI JEPANG DAN KOREA

SELATAN …......................................................................... 79

A. Restorasi Sosial di Jepang .................................................................

B. Restorasi Sosial di Korea Selatan .......................................................86

1. Saemaul Undong...........................................................................

2. Tujuan Saemaul Undong............................................................87

3. Perkembangan Saemaul Undong ............................................... 88

4. Strategi Saemaul Undong …………………………………….......

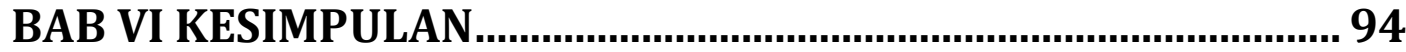

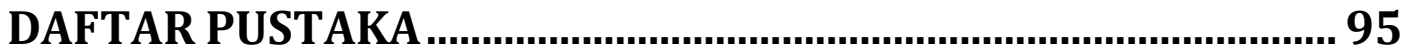

LAMPIRAN

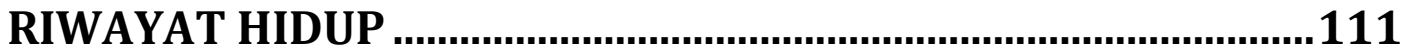




\section{BAB I \\ PENDAHULUAN}

RESTORASI SOSIAL | 1 


\section{A. Definisi Restorasi Sosial}

Setiap tindakan individu baik yang bersifat stimulus maupun respons, dalam koneksivitasnya dengan orang lain harus senantiasa mengacu pada norma yang hidup di masyarakat. Perilaku sifatnya individual tetapi dampaknya tidak bersifat individual, melainkan dapat bersifat sosial. Perilaku seseorang erat kaitannya dengan kepribadian. Seringkali kita menilai kepribadian seseorang dari perilakunya. Pembentukan kepribadian (personality building) merupakan proses panjang yang berlangsung sepanjang hayat dan dipengaruhi oleh lingkungan masyarakatnya. Proses pembentukan kepribadian berlangsung melalui sosialisasi, enkulturasi, kemudian internalisasi, sehingga terbentuk kepribadian pada diri seseorang.

Dalam sosiologi, sosialisasi adalah proses belajar yang dilakukan oleh seseorang semenjak masa kanak-kanak hingga masa tuanya, mengenai pola-pola tindakan dalam berinteraksi dengan segalam ragam individu yang ada di sekelilingnya. Melalui sosialisasi ini, pada diri individu terjadi proses pembinaan kepribadian yang dapat membantunya untuk menyesuaikan diri (adaptasi) dengan lingkungan sosialnya. Ia akan beradaptasi dengan cara hidup dan berpikir kelompoknya (masyarakat) sehingga ia dapat berperan dan berfungsi di lingkungannya.

Proses sosialisasi memerlukan media, di antaranya adalah keluarga, teman sepermainan, sekolah, lingkungan kerja, media massa, organisasi, dan masyarakat. Namun demikian, terdapat beberapa faktor yang turut serta mempengaruhi kepribadian sesorang, diantaranya yaitu faktor genetika (gonetype), pengalaman, pendidikan, perasaan, naluri dan lingkungan, baik lingkungan fisikal maupun lingkungan sosial budaya. Sosialisasi dan kepribadian akan membentuk suatu sistem perilaku (behavior system) yang akan menentukan dan membentuk sikap (attitude) seseorang. 
Kita hidup dalam lingkungan masyarakat yang tidak dapat terlepas dari kebudayaan. Keberadaan masyarakat dan kebudayaan saling mempengaruhi satu sama lain. Kebudayaan lahir dari kehidupan bermasyarakat dan kehidupan bermasyarakat akan berlangsung dengan dukungan kebudayaan. Dengan demikian, maka dalam kehidupan bermasyarakat selain sosialisasi juga terdapat enkulturasi. Enkulturasi merupakan proses belajar yang dilakukan individu tentang adat istiadat dan kebudayaan yang terdapat pada masyarakatnya.

Dengan demikian, enkulturasi memiliki kesengajaan dan tujuan yang hendak dicapai seseorang dalam kehidupan bermasyarakat. Tujuan tersebut adalah agar individu tersebut diterima dan diakui sebagai anggota masayarakat. Perilaku dan tindakan individu tersebut dalam masyarakatnya akan mencerminkan perilaku dan tindakan yang normatif. Pada tahap awal, mungkin saja tindakan dan perilaku tersebut berupa keterpaksaan karena adat istiadat

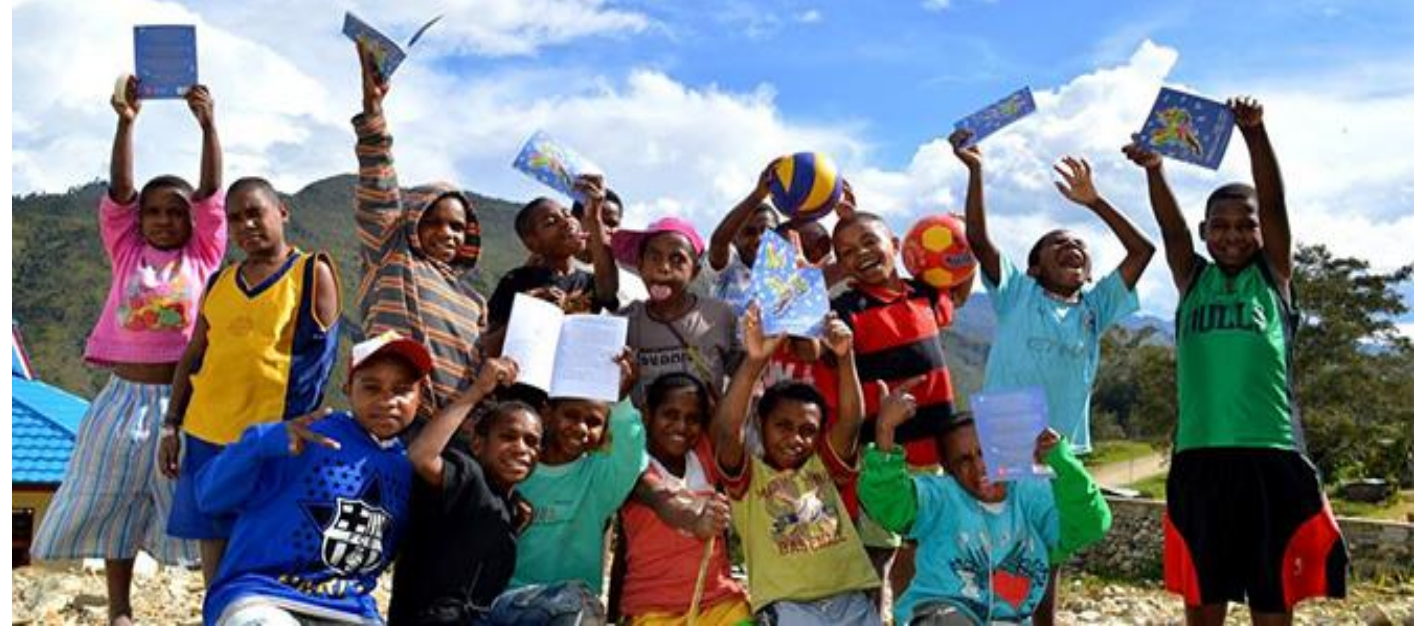

yang terdapat di masayarakat bersifat memaksa (dogmatis) namun sejalan dengan berlangsungnya sosialisasi dan enkulturasi, maka pada diri individu akan berlangsung pula proses internalisasi hingga terbentuk kepribadian. Proses internalisasi akan membentuk kepribadian seseorang yang selaras dengan kepribadian masyarakatnya. 
Jadi kepribadian merupakan keseluruhan perilaku seseorang dan kecenderungannya dalam berinteraksi dengan serangkaian situasi. Kecenderungan yang dimaksud adalah pola perilaku khas dari seseorang yang dilakukan pada setiap situasi tertentu. Sedangkan interaksi dengan serangkaian situasi artinya perilaku tersebut merupakan hasil gabungan dari kecenderungan-kecenderungan perilaku terhadap situasi yang dihadapinya.

Restorasi berasal dari kata to restore, menurut Webster's Third New International Dictionary 'to restore' yang berarti dalam bahasa Inggris to bring back or to put back into the former or original state, atau to bring back from a state of changed condition. Jadi menurut Webster, restorasi bermakna mengembalikan pada keadaan aslinya atau mengembalikan dari perubahan yang terjadi.

Restorasi merupakan penguatan kembali solidaritas, memperteguh kebhinnekaan dan memperkuat restorasi sosial Indonesia melalui kebijakan memperkuat pendidikan kebhinnekaan dan menciptkan ruang-ruang dialog antarwarga. Kebijakan restorasi sosial merupakan salah satu kebijakan yang digalakkan oleh Kementerian Sosial. Konsep Restorasi Sosial berkaitan dengan kebhinekaan dan pluralisme. Pluralisme adalah suatu hal yang mulai memudar di negeri ini, itulah mengapa restorasi sosial menjadi penting.

Restorasi berarti menemukan kembali nilai-nilai yang sudah memudar, dimana salah satunya adalah konsep kemajemukan. Restorasi sosial mengajak rakyat untuk saling menegur sapa tanpa mellihat daerah asal atau status, merasa semua adalah satu.

Restorasi sosial juga merupakan program kesembilan dalam Nawa Cita Presiden Joko Widodo dan Wakil Presiden Jusuf Kalla. Bidang kebinekaan dan memperkuat restorasi sosial lewat wahana pendidikan menempati prioritas ke-9, yaitu: Memperteguh kebhinnekaan dan memperkuat restorasi sosial Indonesia melalui kebijakan memperkuat pendidikan kebhinnekaan dan 
menciptakan ruang-ruang dialog antar warga. Program ke-9 ini dapat dijabarkan menjadi tiga bagian yaitu:

1. Memperkuat pendidikan ke-bhinneka-an dan menciptakan ruang-ruang dialog antar warga. Kata kunci program ini adalah ke-bhinneka-an dan dialog antar warga. Kebhinekaan dapat disederhanakan menjadi keanekaragaman namun terangkum menjadi satu kesatuan. Bahasa, budaya, ragam hayati, lingkungan, di seluruh daerah di Indonesia adalah berbeda. Itu pasti. Namun dengan keanekaragaman itulah harus diciptakan sebuah ruang atau sarana untuk saling memahami. Bukan menonjolkan satu etnis tertentu. Pendidikan adalah wahana yang sangat cocok untuk dialog agar saling memahami dan menghormati. Karena dalam pendidikan hampir ditemui keadaan yang setara. Umur sederajat, kesipan mental setara, penerimaan pengetahuan yang baru hampir bersamaan. Sehingga dari ranah pendidikan sangat memungkinkan membuat wacana tentang kesepahaman dalam hidup bersama.

2. Mengembangkan insentif khusus untuk memperkenalkan dan mengangkat budaya lokal.

Menurut Pangabean, Insentif adalah kompensasi yang mengaitkan gaji dengan produktivitas. Insentif dapat berupa penghargaan. Intensif adalah pahala dalam bentuk kelebihan karena seseorang melakukan sesuatu. Dalam pendidikan, intensif tidak harus berupa uang. Intensif bisa berupa pemberian nilai, yang nantinya akan digunakan sebagai amunisi untuk naik pangkat atau golongan. Penghargaan ini diberikan karena kelebihan seseorang dalam menguasai sebuah bidang atau profesi.

3. Meningkatkan proses pertukaran budaya untuk membangun kemajemukan sebagai kekuatan budaya. Tidak ada orang yang bisa mendefinisikan dengan tepat arti budaya. Budaya itu adalah nafas. Setiap saat bisa melakukan sesuatu, dari yang hanya selalu tetap atau selalu berubah. Budaya harus 
didialogkan dengan budaya lain agar saling kenal. Dengan demikian budaya harus dipublikasikan kepada orang lain, agar mereka mengenal kita. Dari sini akan tumbuh sikap saling menghormati.

\section{B. Tujuan Restorasi Sosial}

Restorasi Sosial dimaksudkan untuk meletakkan Pancasila pada fungsi dan peranannya sebagai dasar filsafat negara, membebaskannya dari stigma, serta diberi ruang pemaknaan yang cukup, untuk merespon tantangan perubahan zaman.

Restorasi Sosial bertujuan untuk mengembalikan atau memulihkan nilai-nilai luhur jati diri atau kepribadian bangsa yang memudar atau melemah sehingga dapat kembali sesuai dengan yang dicitacitakan sebagaimana tercantum dalam pembukaan UndangUndang Dasar 1945 guna mewujudkan masyarakat Indonesia yang hidup rukun, damai, bermoral, dan berbudaya, sehingga bangsa Indonesia mampu menjaga perbedaan dalam persatuan dan kesatuan.

\section{Sifat yang terdapat pada Restorasi Sosial}

Peran Pancasila sangatlah penting dalam pembentukan sifat-sifat pada restorasi sosial. Salah satu sifat yang terdapat dalam restorasi sosial adalah egaliter. Kementerian Sosial mengambil beberapa

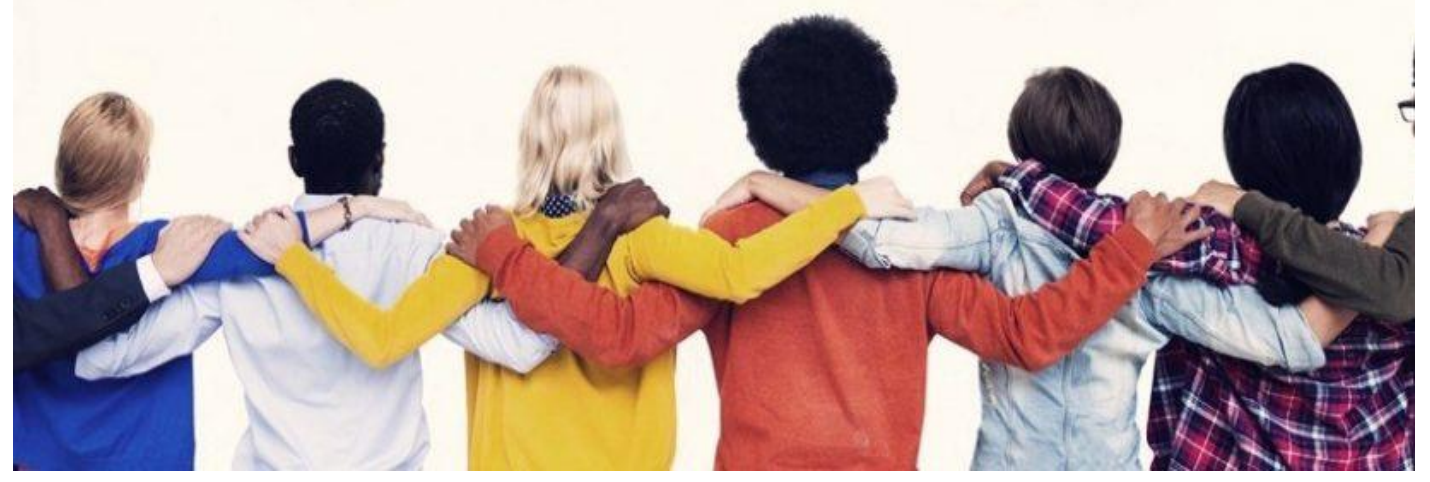

6 | RESTORASI SOSIAL 
nilai dari Pancasila untuk diterapkan di masyarakat, terutama sifat egaliter.

Sifat egaliter merupakan sebuah paham bahwa setiap manusia adalah sederajat. Salah satu cerminan dari sikap egaliter adalah mengajak rakyat untuk saling menegur sapa tanpa membedakan status sosial, dimana yang kaya menyapa yang miskin, yang terdidik menyapa yang tidak terdidik, yang di kota menyapa yang di desa.

\section{Sebab Terjadinya Restorasi Sosial}

Perkembangan zaman membuat masuknya berbagai budaya. Kurangnya literasi dan pemahaman yang baik membuat nilai dan budaya yang mulai memudar, salah satunya adalah pemahaman kemajemukan. Saat ini, salah satu permasalahan yang terjadi di Indonesia terjadi dikarenakan perselisihan dan perpecahan dari rasa toleransi yang mulai memudar. Permasalahan ini kemudian menjadi salah satu bagian dari hal yang diprioritaskan khususnya pada era Presiden Jokowi dan Wakil Presiden Jusuf Kalla menjadi bagian dari Program Nawa Cita. Restorasi berarti menemukan kembali nilai-nilai yang sudah memudar, di mana salah satunya adalah konsep kemajemukan.

\section{E. Hal yang Memperkuat dan Mengancam Restorasi Sosial}

\section{Hal yang dapat memperkuat}

Beberapa hal yang dapat memperkuat restorasi sosial, sebagai berikut:

a. Mengamalkan nilai Pancasila dan semangat Bhinneka Tunggal Ika

b. Mengamalkan nilai Pancasila dan semangat Bhinneka Tunggal Ika dapat dilakukan melalui sikap menghormati 
orang atau kelompok lain menerima perbedaan pendapat orang atau kelompok lain menghargai perbedaan agama orang lain, menciptakan kerukunan, saling tolong menolong seta bermusyawarah dalam mengatasi persoalan.

c. Mengamalkan kembali semangat persatuan bahwa kita semua adalah satu

d. Pengamalan persatuan dapat dilakukan dengan memperteguh rasa nasionalisme yang dapat dimulai dari saling menghargai dan toleransi terhadap sesama yang diiringi dengan semangat persatuan Indonesia.

\section{Hal yang dapat mengancam}

Beberapa hal yang dapat mengancam restorasi sosial, sebagai berikut:

a. Rapuhnya Kesetiakawanan Sosial

Rapuhnya kesetiakawanan sosial dapat diakibatkan melalui mulai tingginya rasa ketidakpedulian, sikap acuh tak acuh terhadap sesama. Hal ini ditandai dengan maraknya berbagai kerusuhan, perkelahian pelajar, saling serang antarumat beragama, saling bunuh, dan kemiskinan yang terus bertambah merupakan sebagian dari indikasi makin lunturnya rasa kesetiakawanan sosial. Oleh karena itu, masyarakat Indonesia perlu meningkatkan semangat gotong royong, asah, asih guna memperkuat rasa kesetiakawanan sosial.

b. Masuknya paham transnasional yang melemahkan Pancasila

Globalisasi memudarkan jarak antar Negara serta mempercepat proses komunikasi. Kemajuan teknologi dan kemudahan yang dirasa diimbangi dengan masuknya paham baru yang mempengaruhi nilai-nilai Pancasila, 
salah satunya adalah paham transnasional. Transnasionalisme adalah fenomena sosial dan agenda penelitian ilmiah yang muncul karena manusia semakin saling terhubung dan perbatasan ekonomi dan sosial antarnegara semakin kabur. Masuknya budaya tersebut harus diimbangi dengan literasi dan pemahaman tentang Pancasila agar tidak tergerusnya bangsa Indonesia menghadapi tantangan global yang semakin berkembang. 
10 | RESTORASI SOSIAL 


\section{BAB II BEBERAPA KONSEP \& TEORI RESTORASI SOSIAL}




\section{A. Landasan Operasional Restorasi Sosial}

Di tengah pudarnya semangat persatuan dan rasa plurarisme membuat diperlukannya penguatan kembali rasa solidaritas guna memperteguh kebhinnekaan dan memperkuat restorasi sosial Indonesia. Berbagai cara dilakukan guna mengembalikan kebhinnekaan Indonesia melalui kebijakan memperkuat pendidikan kebhinnekaan dan menciptakan ruang-ruang dialog antarwarga berdasarkan sifat egaliter dimana kita sebagai masyarakat Indonesia adalah sederajat. Oleh karena itu, peran pemerintah dalam pembangunan karakter bangsa melaui beberapa peraturan seperti:

\section{Peraturan Menteri Sosial Nomor 22 Tahun 2017 mengenai Restorasi Sosial}

Restorasi Sosial merupakan implementasi dari program Nawa cita dan sebagai upaya untuk memperbaiki dan memulihkan nilai-nilai luhur jati diri atau kepribadian bangsa Indonesia. Restorasi sosial dilakukan dengan memberikan penguatan pada masyarakat guna menumbuhkan kembali nilai-nilai luhur budaya bangsa Indonesia.

Penguatan Restorasi Sosial dilaksanakan secara mandiri dan terintegrasi dimulai dari tingkat desa/kelurahan/nama lain sampai dengan tingkat nasional. Restorasi sosial dilakukan oleh Pemerintah Pusat, pemerintah daerah, dan masyarakat. Penguatan Restorasi Sosial dilaksanakan secara terencana, terarah, terpadu, berkelanjutan, dan terkoordinasi. Penguatan Restorasi Sosial dilakukan dengan cara kampanye restorasi sosial, jejaring kerja restorasi sosial, bengkel karakter, dan aksi sosial.

\section{B. Restorasi Sosial dalam Pandangan Agama Islam}

Islam merupakan sebuah agama yang mengajarkan beragam konsep dalam kehidupan. Di antara sekian banyak konsep tersebut, Islam mengajarkan konsep yang baik dan menarik dalam 
kehidupan sosial. Farisi (2016) menjelaskan mengenai konsep sosial dalam Islam yakni dari sudut pandang Al-Qur'an Surat AlImran ayat 133-134 yang dapat kita aplikasikan dalam kehidupan sehari-hari.

\section{Konsep Sosial dalam Islam Dari Sudut Pandang Surat Ali- Imran Ayat 133-134}

Allah SWT berfirman dalam surat Al-Imran ayat 133, "Dan bersegeralah kamu kepada ampunan dari Tuhanmu dan kepada surga yang luasnya seluas langit dan bumi yang disediakan untuk orang-orang yang bertakwa". Dalam ayat ini, Allah memerintahkan untuk menyegerakan diri kepada ampunan dan surga-Nya yang disediakan untuk orang-orang yang bertaqwa (Farisi, 2016). Artinya Allah menghadiahkan ampunan dan surga-Nya untuk orang yang bertaqwa. Pada ayat selanjutnya, pada surat Al-Imran ayat 134, Allah lanjutkan dengan, "(yaitu) orang-orang yang menafkahkan (hartanya), baik di waktu lapang maupun sempit, dan orangorang yang menahan amarahnya dan mema'afkan (kesalahan) orang lain. Dan Allah menyukai orang-orang yang berbuat kebajikan". Pada ayat 134, Allah jelaskan tentang siapa yang dimaksud dengan orang yang bertaqwa pada ayat 133. Allah jabarkan satu persatu tentang mereka yang bertaqwa tersebut ke dalam tiga golongan yang disebut bertaqwa oleh Allah SWT. Konsep sosial dalam ayat ini memiliki arti menuju kepada jalan taqwa (Farisi, 2016).

Pertama, menafkahkan harta di waktu lapang dan sempit (Farisi, 2016). Pada saat ini menafkahkan waktu lapang masih menjadi sulit untuk dilakukan di tengah kehidupan kita di tengah masyarakat. Hal ini telah disebutkan sebagaimana yang dalam ayat ini. Ini merupakan salah satu cara seruan dari Allah kepada kita untuk menggapai predikat taqwa. Banyak sekali riwayat yang menceritakan bagaimana 
Rasulullah Saw dan keluarganya serta para sahabatnya menafkahkan harta di waktu lapang dan sempit.

Salah satu kisah yang dikenal yaitu ketika Sayyidina Ali Bin Abi Thalib melakukan puasa nazarnya selama tiga hari berturut-turut ketika Allah SWT berikan kesembuhan kepada kedua anaknya, yaitu sayyidina Hasan dan sayyidina Husein. Dalam riwayat diceritakan bahwa Sayyidina Ali melakukan puasa bersama istrinya, yaitu sayyidah Fatimah Azzahra dan kedua anaknya. Dalam tiga hari tersebut, keluarga mulia ini selalu didatangi oleh orang-orang yang meminta shadaqah saat berbuka puasa. Sementara makanan buka puasa mereka itulah rezeki yang mereka miliki saat itu, dan makanan buka puasa itu hanyalah sepotong kurma dan sedikit air. Namun, kondisi seperti ini tidak menghalangi sayyidina Ali untuk memberikan kurma yang menjadi makanan buka puasanya tersebut kepada miskin, yatim, dan tawanan perang yang mendatangi rumahnya selama tiga hari berturut-turut. Bahkan istri dan kedua anaknya pun ikut memberikan kurma bagiannya kepada orang-orang tersebut. Dari kisah tersebut, kita belajar tentang pengorbanan dan ikhlas dalam amal.

Kedua, pada ayat 134 mengenai pentingnya menahan amarah yang kemudian dilanjutkan dengan memaafkan sesama (Farisi, 2016). Menahan amarah dan memaafkan merupakan dua hal yang tidak bisa dipisahkan satu sama lainnya.

Seringkali kita sebagai manusia menemui masalah-masalah pada kehidupan sehari-hari guna menguji kesabaran. Diantaranya ada yang mampu bersabar, ada juga yang meluapkannya dengan amarah. Dalam sabdanya, Rasulullah Saw mengatakan bahwa, "orang yang kuat itu bukanlah orang yang menang berkelahi, tetapi orang yang kuat adalah orang yang mampu menahan dirinya di waktu marah" (H.R. 
Bukhari). Setelah menahan amarah, sikap memaafkan meninggikan derajat manusia di hadapan Allah SWT sebagai manusia bertaqwa.

Memaafkan segala kesalahan ikhlas tanpa mengungkitungkit kembali permasalahan yang telah kita maafkan tersebut. Namun terdapat pula yang mampu menahan amarah tetapi tidak memaafkan, atau memaafkan tetapi tidak mau bersilaturahim dan tegur sapa. Tujuan dari ayat ini adalah memaafkan berarti melupakan kesalahan orang yang kita maafkan tanpa syarat apapun (Farisi, 2016).

Salah satu tujuan dari mempelajari pemahaman agama adalah untuk meningkatkan pemahaman agama agar kita bisa berbuat lebih baik (Farisi, 2016). Salah satu sikap yang dapat ditunjukkan ketika terdapat orang lain yang menghina, kita dapat dengan tenang berkata dengan lebih baik dalam menghadapinya.

Rasulullah Shallallahu 'Alaihi Wa Alihi Wasallam tidak pernah membalas keburukan dengan keburukan. Allah SWT berfirman dalam surat Al-Isra' ayat 7, “Jika kamu berbuat baik (berarti) kamu berbuat baik bagi dirimu sendiri dan jika kamu berbuat jahat, maka (kejahatan) itu bagi dirimu sendiri ...".

Ini adalah sebuah ayat yang menjelaskan bahwa segala perbuatan baik akan kembali kepada pembuatnya dan keburukan kembali kepada pelakunya. Sehingga apabila terdapat seseorang yang berbuat buruk kepada kita dengan perkataan atau sikap buruk, tanpa kita balas pun itu sudah pasti kembali kepada dirinya, dan yang kembali kepada kita adalah sikap kita sendiri.

Oleh karena itu, kita harus percaya dan yakin bahwa setiap perbuatan dan sikap dengan diri kitalah yang membentuk kebaikan ataupun keburukan yang akan datang pada diri kita 
sendiri sehingga senantiasa kita harus berbuat baik kepada diri sendiri dan orang lain.

\section{Definisi Ilmu Sosial Profetik (ISP)}

Muttaqin (2015) menjelaskan dalam Menuju Sosiologi Profetik bahwa Ilmu Sosial Profetik (ISP) merupakan tugas yang berat yang harus diemban agar dapat menjadikan nilainilai Islam dapat diterima sehingga Islam sebagai rahmat. Secara kelahirannya ISP merupakan suatu hasil dari pemikiran tokoh yang prihatin melihat realitas sekarang dan mencoba untuk melakukan transformasi guna menciptakan yang lebih baik. ISP sebagai hasil dari pemikiran perlu mendapatkan pengkritisan sebagai sarana pembenahan baik segi teori ataupun metodologinya sehingga ISP dapat sejajar dalam paradigma ilmu sosial yang lain.

ISP selama ini, merupakan suatu gerilya intelektual dan masih dimiliki oleh kalangan akdemisi tetapi hanya sekedar wacana dan discausce (Muttaqin, 2015). Pemahaman kalangan akademisi tentang ISP belum dapat disejajarkan paradigma ilmu sosial yang lain. Pemahaman tersebut menjadikan akademisi masih belum serius, menjadikan ilmu ini setara dan sejajar dengan paradigma ilmu sosial yang lain. Oleh karena itu, perlu adanya kajian yang lebih dalam tentang ISP guna dapat merekonstruksinya agar ISP dapat digunakan untuk melihat dan menyelesaikan problem sosial yang selama ini terjadi. Untuk lebih jauh dapat dilihat pemikiran tokoh yang mencoba melontarkan ISP sebagai alternatif dalam teori sosial kontemporer (Muttaqin, 2015).

Sebagaimana dalam sosiologi pengetahuan ISP sebagai hasil dari pemikiran agar tidak membeku, menjadi ideologi dan menjadi mitos baru, maka perlu melakukan refleksi diri dan evaluatif (Muttaqin, 2015). ISP yang telah dijabarkan oleh Kuntowijoyo tidak dapat dilepaskan dari realitas yang terjadi pada saat itu. Secara sederhana kelahirannya, ISP yang 
digagas oleh Kuntowijoyo dapat dipetakan menjadi dua macam; pertama interaksi Kuntowijoyo dengan berbagai macam ilmu sosial sehingga memunculkan respon atau terhadap ilmu sosial yang ada, dan tokoh yang memiliki karakter transformatif (Muttaqin, 2015). Kedua, respon terhadap kondisi realitas (kerangka berfikir atau arus besar pemikiran yang berkembang) sekarang dimana ISP dilontarkan.

Pertama, interaksi Kuntowijoyo dengan berbagai macam ilmu sosial (Muttaqin, 2015). Kuntowijoyo merupakan sosok intelektual yang senang membaca, hal terlihat melalui karyakaryanya yang berkaitan dengan teori perubahan sosial. Selain itu, ia juga sempat menggunakan teori sosial dari tokoh Marx, Weber, dan Durkheim. Selanjutnya dalam melihat periodesasi perkembangan umat Islam, Kuntowijoyo menggunakan analisis dari Comte.

Setelah melakukan kajian terhadap ilmu sosial, kemudian ia mencoba memberikan respon ataupun tanggapan terhadap kajian yang dilakukannya. ISP merupakan ilmu sosial alternatif terhadap ilmu sosial yang selama ini berkembang cenderung bercorak liberal dan logika positivistik (Muttaqin, 2015). Sebagaimana dalam era post modernis ilmu sosial saling berevolusi dalam dataran paradigmatik. Begitupula, dengan ISP merupakan kritisi terhadap tiga ilmu sosial yang selama ini berkembang seperti ilmu sosial yang bercorak posivistik, konstruksionisme yang bercorak liberal dan ilmu sosial yang bercorak kritis memiliki sifat perfeksionis.

Ilmu sosial positivistik, dimana dalam memandang masyarakat bagaikan sebuah sistem atau struktur. Letak pengkritisian terhadap ilmu ini dalam memandang manusia tidak memiliki kebebasan, individu bersifat deteministik, ilmu ini tidak mengupayakan untuk melakukan transformasi 
sosial, tetapi ilmu ini lebih cenderung mempertahankan status quo (Muttaqin, 2015).

Ilmu sosial positivistik dipelopori oleh Comte dan di kembangkan oleh Durkheim. Sedangkan untuk ilmu sosial konstruktivis dipelopori oleh Weber, ilmu sosial konstruktivis sama dengan ilmu sosial positivistik ia bersifat liberal. Sedangkan yang membedakan dari ilmu ini, menjelaskan dan memaparkan relaitas sosial itu beragam dan memiliki keunikan tertentu sehingga tidak dapat digenaralkan.

Dalam ilmu sosial konstruktivis memandang manusia sebagai subjek yang bebas dan memiliki kesadaran dan membentuk sistem sedangkan pengkritisian terhadap ilmu kritis yang bersifat perfeksionis (Muttaqin, 2015). Kuntowijoyo memaparkan dengan meminjam analisisnya Michael Root bahwa ilmu sosial yang bersifat perfeksionis seperti aliran Marxian, Freudian, dan Feminisme jatuh dalam dataran ilmu yang deteministik. Ilmu tersebut jatuh dalam dataran determinstik dikarenakan seperti Marxian mengandung determinisme ekonomi, Freudian dalam determinisme biologis sedangkan feminisme mengalami determinisme seksual (Kuntowijoyo, 2001). Melihat ilmu sosial yang berkembang di era sekarang maka ia menawarkan ISP sebagai ilmu yang serat nilai, berpihak dan mengupayakan transformasi sosial, seperti ilmu sosial kritis yang telah digagas oleh Mazhab Frankfurt yang telah dikembangkan oleh Jurgen Habermas.

Interakasi Kuntowijoyo dengan tokoh-tokoh yang mempengaruhinya seperti Moeslim Abdurrahman, Muhammad Iqbal dan Roger Garaudy. Moeslim Abdurrahman dengan pemikiran teologi trasformatif, dalam hal ini Kuntowijoyo lebih memilih ilmu sosial dari pada teologi (Muttaqin, 2015). Hal tersebut dikarenakan akan 
membingungkan dan kurang cocok diterjemahakan, bila menggunakan teologi maka dapat memunculkan teologi yang lain seperti teologi pembebasan, teologi lingkungan dan yang lain. Sedangkan pemahan umat tentang permasalahan teologi merupakan yang tetap tidak berubah, oleh karena itu ia lebih memakai ilmu sosial.

Pembaharuan teologi agar agama diberi tafsiran baru dalam rangka memahami realitas sosial menyebabkan salah satu alasan terjadi pergantian dari teologi dalam ilmu sosial (Muttaqin, 2015). Hal ini dikarenakan jika gagasan, metode yang efektif yang dimaksud dalam rangka mengelaborasi ajaran agama kedalam suatu teori sosial. Lingkup dari sasaran ilmu sosial tersebut lebih dari rekayasa untuk transformasi sosial. Lingkup bukan dalam dataran permanen seperti teologi, tetapi aspek yang temporal, empiris dan historis. Maka Kuntowijoyo lebih cenderung menggunakan ilmu sosial ketimbang teologi. Kebutuhan yang dilakukan dalam trasformasi sosial bukan saja perangkat yang bersifat objektif, tetapi melalui teori sosial dapat melakukan transformasi bersifat objektif dan juga merupakan lahan garap yang bersifat empiris (Muttaqin, 2015).

Kuntowijoyo mengambil kata profetik setelah mendapatkan gambaran tetang konsep kesadaran profetis yang dilontarkan oleh Iqbal dalam bukunya Membangun Kembali Pemikiran Agama Islam (Muttaqin, 2015). Muhammad Iqbal menggambarkan tentang mi'rajnya Nabi Saw yang bertemu dengan Tuhan, seandainya nabi seorang mistikus atau sufi, ia pasti tidak akan kembali karena sudah tentram dan tetang bersama-Nya. Tetapi ini lain, Nabi kembali ke bumi untuk melakukan perubahan dalam rangka merubah sejarah melakukan transformasi profetik.

Selanjutnya kata profetik juga terinspirasi dari seorang Filosof Prancis, Roger Garaudy dalam bukunya Janji-Janji 
Islam, disana dipaparkan bahwa peradaban Barat tidak memuaskan dikarenakan terombang-ambing dalam kedua kutub besar yakni idealisme dan materialisme (Muttaqin, 2015). Filasafat barat (kritis) lahir yang mempertanyakan bagaimana pengetahuan itu dimungkinkan kemudian mengusulkan agar membalik pertanyaan agar bagaimana wahyu dimungkinkan. Dalam rangka untuk menghindari kehancuran peradaban maka pilihan satu-satunya agar menggunakan kembali warisan Islam (filsafat kenabian). Filsafat barat telah "membunuh" Tuhan dan manusia, maka ia menganjurkan untuk menggunakan filsafat kenabian dan mengakui wahyu sebagai salah satu dari sumber kebenaran.

Realitas saat ini merupakan zaman post modernisme (Muttaqin, 2015). Sebagaimana dalam tradisi modernisme yang muncul dari abad pertengahan pada masa pencerahan dari seorang filosof Prancis, Rene Descartes dengan semboyannya catigo ego sum. Menurut Kuntowijoyo dalam zaman pencerahan yang berkembang menjadi modernisme terdapat dua ciri yang penting dan yang membedakan dengan era post modernism.

Pada zaman modern merupakan kerangka berfikir sekuleristik, memandang dengan differentiation (pemisahan) dan terjadinya humanisme antroposentris (Muttaqin, 2015). Kerangka pikir sekuleristik mencoba memisahkan dengan tegas antara agama dengan ilmu pengetahuan, politik, ekonomi, dan Negara. Modernisme yang dikumandangkan humanisme antroposentris berkembang bukannya telah memberikan kemerdekaan terhadap manusia tetapi sebaliknya, yang terjadi sampai sekarang adalah dehumanisasi. Dehumanisasi dikarenakan manusia dengan menciptakan ilmu pengethuan dan teknologi yang memiliki tujuan utama untuk mempermudah manusia tetapi sekarang manusia terjebak oleh sistem yang telah dibuat menjadikan 
manusia telah diperbudak oleh sistem dan teknologi itu. Sebagaimana yang telah dikemukaka oleh Mazhab Frankfurt kerangka pikir modernisme menjadi rasional teknokratis atau dalam bahasa Herbert Marcus menjadi manusia satu dimensi.

Realitas sekarang merupakan era post modernisme dimana dalam zaman ini merupakan kritik terhadap modernism dan patologi yang dihadapinya (Muttaqin, 2015). Post modernisme memiliki ciri yang penting adalah dedifferentiation. Post-modernism merupakan penyapaan kembali antara agama dan ilmu pengetahuan dan tidak berdiri sendiri atau terpisah (Muttaqin, 2015). Agama sebagai inspirasi dan sumber nilai/etik dari ilmu pengetahuan. Penyapaan terhadap agama dari ilmu pengetahuan ini yang mencoba melakukan integrasi antara ilmu dengan agama guna menjawab permasalahan modernitas dimana terjadinya dehumanisasi dan kerusakan ekologi (Muttaqin, 2015).

ISP memiliki peluang agar dapat diterima sebagai salah satu disiplin ilmu dikarenakan ISP dapat mengintegrasikan antara ilmu pengetahuan dengan agama (Muttaqin, 2015). Agama menjadikan nilai untuk melakukan transformasi sosial dan pengintegrasian nilai-nilai agama dalam masyarakat. Bentuk transformasinya ada arahan kemana transformasi itu akan dibawa. ISP sebagai alat transformasi sedangkan bentuk transformasinya merupakan transfomasi profetik guna mewujudkan Khoirul Umat.

ISP memiliki tujuan untuk memberikan jawaban dari ilmu sosial transformatif. ISP menjelaskan bagaimana transformasinya untuk apa oleh siapa dan diarahkan kemana dalam transformasinya sedangkan dalam ilmu sosial transformatif memiliki jawaban yang kurang jelas (Muttaqin, 2015). ISP bukan hanya alat untuk melakukan transformasi 
tetapi diarahkan sesuai dengan cita-cita dan etis profetis. Cita-cita profetis dalam ISP merupakan apa yang telah diidamkan oleh masyarakatnya. Cita-cita profetis diderivasi dari surat al Imran 110.

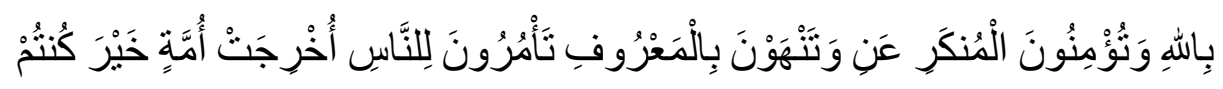

Artinya: "Kamu adalah umat yang terbaik yang dilahirkan untuk manusia, menyeru kepada yang ma'ruf dan mencegah dari yang munkar dan beriman kepada Allah Swt" (QS. al Imran; 110).

Menurut Kuntowijoyo terdapat empat hal yang tersirat dalam ayat tersebut; pertama merupakan konsep umat yang terbaik, kedua aktivisme sejarah, ketiga pentingnya kesadaran, dan keempat etika profetik (Muttaqin, 2015).

Pertama أأُمَّة خَيْرَ ) konsep umat yang terbaik bagi Islam merupakan mengerjakan ketiga hal tersebut dalam ayat bukanlah sekedar hadiah dari Tuhan (Muttaqin, 2015). Tetapi konsep umat yang terbaik ini merupakan tantangan agar aktif dan bekerja keras dalam sejarah.

Kedua للِنَّاسِ أُخْرِجَتْ ) aktivisme sejarah merupakan bentuk kerja keras ditengah umat manusia dan keterlibatan umat Islam dalam menentukan sejarah (Muttaqin, 2015). Menurut ajaran Islam yang menekankan bahwa pengetahuan yang didapatkan harus ditransformasikan bukan hanya untuk diri tetapi juga untuk orang lain.

Ketiga pentingnya kesadaran (Muttaqin, 2015). Bentuk kesadaran dalam Islam nilai-nilai Ilahiah menjadi tumpuan dalam melakukan aktivisme sejarah. Kesadaran tersebut bersifat idependensi yang bertumpu pada Tuhan bukan kepada struktur atapun kepada manusia. Kesadaran yang ditekankan pada struktur atau individu menjadikan bentuk kesadaran dalam Marxisme maka yang terjadi merupakan 
dalam bentuk individualisme, eksistensialisme, kapitalisme, dan liberalisme.

Keempat tetang etika profetik yang dapat dilakukan oleh siapa saja (Muttaqin, 2015). Etika profetik merupakan

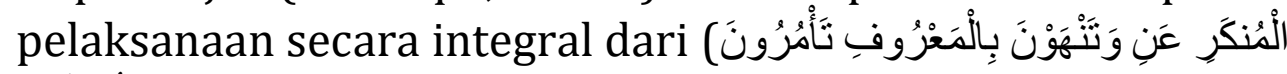

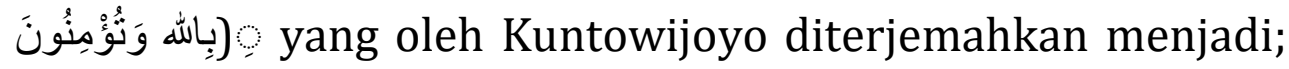
humanisasi, liberasi dan trasendensi.

\section{Pilar ISP}

ISP dalam pembacaan dan pengalisaan terhadap realitas sosial memiliki tiga ranah alat pandang, dimana alat pandang tersebut saling berkaitan antara yang satu dengan yang lain tidak dapat dipisahkan. Pilar ISP merupakan bagaimana ISP dihadapkan pada realitas empiris, sehingga pendekatan yang digunakan oleh ISP pun bersifat empiris analitis dengan menghadapkan al Qur'an dengan realitas sosial seperti industrialisasi, kelas sosial dan permasalahan yang lain (Muttaqin, 2015). Penelitian yang dilakukan bersifat partisipatoris, grounded research. ISP memiliki tiga pilar yag diderivasi dari surat al Imron 110 yakni tafsirn kreatif dari

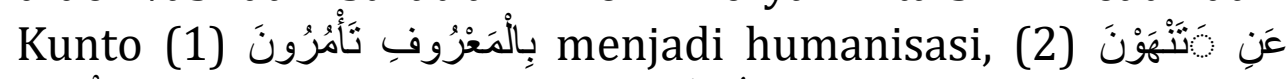
menjadi liberasi, dan (3) الْمُنكِرِ

\section{Humanisasi}

Humanisasi merupakan semangat dari peradaban Barat yang percaya pada the idea of progress, demokrasi, HAM, Liberalisme, kebebasan, kemanusiaan, kapitalisme dan selfishness (Muttaqin, 2015). Humanisasi merupakan proses pemanusiaan manusia dalam bahasa agamanya mengembalikan posisi manusia pada fitrahnya. Proses humanisasi merupakan jawaban dari patologi masyarakat modern yang mengalami dehumanisasi yang diakibatkan oleh kemajuan teknologi dan informasi. 
Saat ini, manusia bergantung pada teknologi (Muttaqin, 2015). Manusia pada masyarakat modern dengan kerangka pikir rasional teknokratis sehingga menjadi manusia satu dimensi, jatuh dalam dataran kehinaan dan menghilangnya sisi atau dimensi manusia yang lain. Oleh karena itu, Kuntowijoyo mencoba melakukan humanisasi yang berdasar kepada agama, dimana merujuk iman dan amal soleh. Hal ini seperti diungkapkan dalam surat at Tin ayat 5-6 bahwa manusia jatuh kedalam tempat keterhinaan, kecuali orangorang yang beriman dan beramal soleh.

Pengembalian kemuliaan manusia yang terjatuh pada kehinaan dengan mengembalikan manusia pada fitrahnya sehingga dapat memenuhi semua dimensi yang dimiliki oleh manusia (Muttaqin, 2015). Humanisme yang dilontarkan oleh ISP merupakan pengkritisian humanisme barat (humanisme antroposentris) yang menyebabkan majunya peradaban barat tetapi sekarang mereka mengalami dehumanisasi. Humanisme yang ditawarkan oleh ISP humanisme yang didasarkan pada agama jadi humanisme teo-antroposentris.

Gagasan humanisasi tersebut diterjemahkan dalam teori sosial menjadi ilmu sosial yang menggunakan pendekatan struktural fungsional (Muttaqin, 2015). Analisis yang digunakan oleh Kuntowijoyo dalam karyanya memandang persolan masyarakat menggunakan pendekatan makro atau struktur dan dalam humanisasi lebih cenderung menggunakan teori sosial fungsional dan menggunakan pendekatan interpretatif dalam memandang manusia.

\section{Liberasi}

Liberasi dalam ISP selaras dengan berbagai teori sosial yang bercorak partisipatif dan membawa etik tertentu, seperti prinsip sosialisme (marxisme, komunisme, teori 
ketergantungan dan teologi pembebasan) yakni semua membawa pada liberation (Muttaqin, 2015). Mereka meyakini bahwa perkembangan dapat dicapai dengan kebebasan. Liberasi yang ditawarkan oleh ISP dalam dataran ilmu buka dalam dataran ideologis. Liberasi yang ditawarkan oleh Kunto dalam ISP paling tidak empat ranah seperti bidang ekonomi, sosial, budaya, dan politik dalam ranah sistem ilmu pengetahuan.

Liberasi sistem ilmu pengetahuan dapat membebaskan manusia dari sistem pengahuan materialis, dominasi struktur misalkan kelas dan seks. Dalam hal ini, Islam memandang kesetaraan antara laki-laki dan perempuan. Liberasi dari sistem sosial budaya merupakan transformasi sosial umat Islam yang berkembang dari masyarakat agraris menuju masyarakat industri (Muttaqin, 2015). Oleh karena itu, dalam transformasi tersebut diperlukan ilmu sosial yang bersifat communitarian. Liberasi dalam ekonomi bagaimana menciptakan suatu sistem ekonomi yang bercorak keadilan, hal ini dikarenakan adanya kesenjangan ekonomi.

Penggagasan tentang keadilan ekonomi merupakan nilainilai yang ada dalam ajaran Islam. Hal ini sebagaimana telah diungkapkan dalam al Qur'an dalam surat al Hasyr; 7 "supaya harta tidak hanya beredar diantara orang-orng yang kaya diantara kamu", selanjutnya dalam surat al Zukhruf; 32 "apakah mereka yang berhak membagi-bagi rahmat Tuhanmu?".

Liberasi dalam ISP ini dapat diterjemahkan dalam ilmu sosial selaras dengan pendekatan Marxisme. Hal ini dapat dilihat dari analisis yang telah digunakan oleh Kuntowijoyo dalam memandang tertentu seperti persolan kemiskinan ia lebih cenderung memakai Marxian, tetapi bukan dalam dataran penghapusan kelas tetapi agar bagaimana tercita struktur yang berkeadilan. 


\section{Transendensi}

Transendensi dalam ISP merupakan menjiwai dari kedua unsur yaitu menjadi prinsip dalam semua agama dan filsafat perennial (Muttaqin, 2015). Transendensi merupakan kunci beriman kepada Allah yang menjadi ruh alam humanisasi dan liberasi dalam melihat dan pengaplikasian dari ISP.

Menurut Erich Fromm jika tidak menerima otoritas Tuhan secara otomatis akan berdampak pada; (1) relativisme penuh, dimana nilai dan norma sepenuhnya merupakan urusan pribadi. (2) nilai tergantung pada masyarakat sehingga yang dominan akan menguasai. (3) nilai tergantung pada kondisi biologis.

Oleh karena itu, menurut Kuntowijoyo agar umat Islam meletakan Allah sebagai pemengang otoritas, Tuhan yang maha objektif. Trasendensi yang dimaksudkan oleh Kuntowijoyo dalam ISP merupakan penggunaan wahyu sebagai salah satu unsur dalam ilmu sosial. Paradigma wahyu digunakan dalam ilmu sosial yang dilakukan oleh Kuntowijoyo dengan melalui objektifikasi terhadap ayat-ayat al Qur'an agar kebenaran yang didalamnya dapat diterima oleh seluruh manusia.

Objektifikasi merupakan upaya rasionalitas nilai yang diwujudkan dalam perbuatan rasional sehingga orang luar dapat menikmati tanpa harus menyetujui nilai asalnya (Muttaqin, 2015). Melalui objektifikasi menjadikan Islam yang bekerja secara aktif, sehingga menjadikan Islam sebagai rahmat bagi alam semesta dalam artian Islam diturunkan sebagai rahmat kepada siapa pun tanpa memperhatikan warna kulit budaya dan sebagainya. Objektifisikasi merupakan konkritisasi dalam kenyakinan internal, perbuatan ini dapat objektif jika dapat dirasakan oleh non 
muslim sebagai suatu yang natural atau wajar, tidak sebagai perbuatan keagamaan.

Kuntowijoyo mencontohkan tentang objektifisakasi ayat al Qur'an agar nilai-nilai Islam dapat diterima oleh semua umat manusia. Kesetiakawanan nasional adalah objektifikasi dari ajaran tentang ukuwah (Kuntowijoyo, 1997).

ISP yang dilontarkan oleh Kuntowijoyo diterjemahkan dari sifat ilmunya maka ISP bersifat partisipatoris untuk melakukan perubahan dan sekaligus arah dari perubahan itu sendiri (Muttaqin, 2015). Ilmu ini serat dengan nilai-nilai, tidak status quo, dan berpihak kepada kemanusiaan guna menciptakan khoirul ummat. ISP ilmu dalam aliran yang perfeksionis dan bersifat communitarian.

Dalam metodologi penelitian ISP yang diharapkan penelitian lapangan dan langsung melakukan emansipasi guna menciptakan keadilan (Muttaqin, 2015). Cara pencarian data yang dilakukan ISP dengan metode wawancara dan observasi partisipatoris. ISP merupakan turunan dari surat al Imran 110 menghasilkan tiga paradigma guna mewujudkan masyarakat yang dicita-citakan. Tetapi masing-masing paradigma dalam ISP yang dalam memandang masyarakat bersifat integral dan menyeluruh, jika diturunkan dalam metodologi penelitian maka dapat berdiri sendiri tanpa adanya saling sapa. Kuntowijoyo hanya mencoba dalam analisis dengan menggunakan ketiga paradigma tersebut, tetapi ia terkadang dalam melihat fenomena sosial cenderung dengan pendekatan Marxian kadang juga fungsional. Selanjutnya dalam ilmu sosial yang bersifat partisipatoris ada rangkaian dalam menjalankan keseimbangan antara teori dan praktek seperti dalam ilmu sosial kritis, dalam konsep praksisnya kerja dan komunikasi. Jika mau ditarik kedalam ISP Kuntowijoyo belum sempat merumuskannya. Tetapi jika ditelusuri dari berbagai 
karyanya ia mencoba mengintergrasikan ilmu sosial yang dari barat dengan nilai-nilai Islam.

Praksis ISP dengan mendialogkan agama ini, dengan realitas menjadikan agama berperan dan mengupayakan untuk melakukan transformasi dengan didasari oleh nilai-nilai agama (Muttaqin, 2015). Transfomasi yang didasarkan oleh nilai-nilai agama menjadikan bentuk tranformasi serta arahannya jelas. Hal ini dapat dilihat bentuk transformasi yang dilakukan oleh nabi Muhammad dan nabi Musa dalam menghilangkan penindasan umatnya dari Fir'aun. Bentuk transformasi yang dilakukan menciptakan masyarakat yang berkeadilan dan didasarkan dengan nilai-nilai Ilahiah sebagai sarana dan jalan dalam rangka beribadah kepada Tuhan.

\section{Paradigma dalam Ilmu Sosial}

Di tengah kehidupan masyarakat, banyak sumber pengetahuan yang bersifat taken for granted, sumber tanpa perlu diolah lagi tetapi diyakini akan membantu memahami realitas kehidupan ini. Masyarakat dapat langsung begitu saja memakai pengetahuan taken for granted tersebut sebagai sebuah pegangan yang diyakini benar atau berguna untuk memahami dunia dimana ia hidup. Jenis pengetahuan tanpa diolah lagi tentu saja banyak dan tersebar, mulai dari sistem keyakinan, tradisi agama, pandangan hidup ideologi, paradigma dan juga teori, dan termasuk didalamnya teori sosial. Dalam masyarakat intelektual, terutama dalam tradisi positivisme lazim untuk mengambil sumber pengetahuan taken for granted tersebut dari ranah paradigma dan teori.

Kendati demikian, teori sebenarnnya bukan hanya untuk kalangan intelektual atau kalangan expert, mesti tidak sedikit yang berpandaangan hanya kalangan intelektual atau akademisi saja yang membaca realitas sosial tidak dengan telanjang, melainkan 
dengan kacamata teori tertentu. Memanga telah menjadi tradisi dikalangan intelektual dalam membaca realitas sosial dengan menggunakan kacamata atau teori tertentu (Maliki, 2003).

Dalam beberapa hal, teori ilmiah berbeda dengan asumsi-asumsi yang telah ada dalam kehidupan sehari-hari dan secara tidak sadar telah dimiliki orang. Pengetahuan yang dimiliki oleh seseorang dalam kehidupan sehari-hari dapat menjadi suatu teori yang merupakan bagaian dari kegaitan ilmiah. Dalam memamasuki era pelahiran ini merupakan kajian dari teori yang eksplisit, sehingga menjadi objektif, kritis, dan lebih abstrak dari pada yang dilaksanakan dalam kehidupan sehari-hari. Dalam proses pemebentukan teori tidak pernah muncul dari awal, tidak mungkin bagi ahli teori sosial untuk menghilangkan pengaruh-pengaruh pengalaman sosial pribadinya, pengaruh dari pengalaman ini cara pandang dunia sosial. Proses pembentukan teori berlandaskan pada gambaran fundamental tertentu mengenai kenyataan sosial. Gambaran tersebut dapat melingkupi asumsi filosofis, dasar mengenai sifat manusia dan masyarakat, atau sekurang-kurangnya pandangan yang mengatakan bahwa keterturan tertentu akan dapat diramalkan dalam dunia sosial. Teori ilmiah lebih menggunakan metodologi dan bersifat empiris (Jonshon, 1994).

Pengklasifikasian dalam ilmu sosial terdapat tiga perfektif besar yang berkembang selama ini, yakni perfektif struktural fungsional, struktural konflik serta konstruksionisme. Ketiga aliran tersebut masing-masing mengkritik dengan mematahkan proposisi, konsep maupun teori yang ditawarkan satu sama lain. Namun kritik tersebut tidak dapat menggoyahkan hegemoni mereka masingmasing dan ketiganya masih memiliki pengikut yang setia. Ketiga teori sosial tersebut, merupakan upaya dalam memahami realitas kehidupan. Dengan teori sosial diharapkan orang dapat menghimpun dan memaknai informasi secara sistematik bukan saja untuk menyumbang pengembangan teori, tetapi lebih penting 
lagi untuk memecahkan persolan dan untuk tujuan keberhasilan dalam mengarungi pergumulan kehidupan (Maliki, 2003)

Paradigma dapat didefinisikan bermacam-macam sesuai dengan sudut pandang masing-masing orang. Ada yang menyatakan paradigma merupakan citra yang fundamental dari pokok permasalahan suatu ilmu. Paradigma menggariskan apa yang seharusnya dipelajari, pernyataan-pernyataan yang seharusnya dikemukan dan kaidah-kaidah apa yang seharusnya diikuti dalam menafsirkan jawaban yang diperolehnya. Paradigma diibaratkan sebuah jendela tempat orang mengamati dunia luar, tempat orang bertolak menjelajahi dunia dengan wawasannya (world view) (Salim, 2001).

Paradigma sosial mengacu pada orientasi perseptual dan kognitif yang dipakai oleh masyarakat komunikatif untuk memahami dan menjelaskan aspek tertentu dalam kehidupan sosial. Paradigma sosial terbatas pada pandangan dua hal; pertama, paradigma sosial yang hanya dimiliki oleh kalangan terbatas dan tidak melulu diterima oleh anggota masyarakat. Masyarakat yang menerima paradigma ini masyarakat ilmiah, terciptanya komunikasi guna menciptakan paradigma sosial. Kedua, paradigma sosial yang berlaku dalam aspek tertentu dari kehidupan dan bukan aspek yang menyeluruh. Paradigma sosial lebih terbatas dalam ruang lingkung penerimaan dari pada pandangan dunia yang berlaku, sebagai elemen dasar dari paradigma sosial merupakan pandangan dunia baik dalam komponen dasar, keyakinan atau sistem keyakinan dan nilai-nilai yang terkait. Sebagaimana dalam pandangan Stephen Cotgrove paradigma memberikan kerangka makna, sehingga pengalaman memberikan makna dan dapat dipahami (Maliki, 2003).

\section{Ilmu Sosial Posivistik}

Positivistik merupakan paradigma ilmu pengetahuan yang paling awal muncul dalam dunia ilmu pengetahuan. Keyakinan paham aliran ini pada ontologi realisme yang 
menyatakan bahwa realitas ada (exist) dalam kenyataan berjalan sesuai dengan hukum alam (natural lows). Upaya penelitian untuk mengungkapkan kebenaran realitas yang ada, dan bagaimana sesungguhnya realitas itu berjalan. Positivistik muncul pada abad 19 yang dipelopori oleh Auguste Comte.

Dalam pencapaian kebenaran maka harus menanyakan lagsung pada objek yang diteliti, dan objek dapat memberikan jawaban langsung pada peneliti yang bersangkutan. Metodologi yang digunakan eksperimen empiris atau metodologi yang lain agar temuan yang diperoleh benar-benar objektif dan menggambarkan yang sebenar-benarnya (Salim, 2001). Kaum positivistik mempercayai masyarakat merupakan bagian dari alam dan bahwa metode penelitian empiris dapat dipergunakan untuk menemukan hukum-hukumnya.

Beberapa tokoh ahli pada positivistik adalah:

\section{Herbert Spencer}

Menurut Spencer bahwa objek dari ilmu sosial hubungan timbal balik dari unsur-unsur masyarakat seperti pengaruh norma-norma atas kehidupan keluarga, hubungan antara lembaga politik dan lembaga keagamaan. Unsur dalam masyarakat memiliki hubugan yang tetap dan harmonis dan merupakan suatu integrasi (Soekanto, 2013). Spencer memiliki kepercayaan bahwa manusia bersifat merdeka, dan setiap individu dengan bebas menggunakan adatnya serta kebebasan itu harus tetap dijaga agar tidak dapat mengganggu kebebasan yang lain. Ia juga menjelaskan tentang pentingnya lembaga sosial dalam membentuk karakter individu, dan hubungan manusia dengan masyarakat merupakan proses dua jalur. Secara sederhana menurut Spencer bahwa masyarakat dibentuk oleh individu 
(Hotman M. Siahaan, Pengantar Kearah Sejarah dan Teori Sosiologi).

Perbedaan pemikiran antara Comte dan Spencer tetapi saling melengkapi dalam tradisi ilmu sosial yang bercorak positivistik, Comte dalam memandang masyarakat dengan cara menjelaskan perkembangan ersepsi manusia, menekankan perlunya aktualisasi ide, dan Spencer menekankankan perlunya aktualisasi benda. Comte berusaha menginterpretasikan genetik dari fenomena yang membentuk alam dan Spencer menafsirkan genetik dari fenomena yang membentuk alam.

Comte lebih bersifat subjektif sedangkan Spencer bersifat objektif. Spencer tidak hanya tertarik pada perkembangan ide, tetapi mengembangkan ide pada perubahan korelatif dalam organisasi sosial, tertib sosial struktur maupun progres. Teori yang dimiliki oleh Spencer berupa analisa objektif seperti untuk pertumbuhan, evousi linier, multilinier, tipe-tipe sosial, dan good society. Kemudian pemikirannya diterjemahkan menjadi diferensisasi sebagai interelasi dan integrasi berbagai aspek penting dalam sistem masyarakat. Ilmuwan sosial yang diajurkan oleh Spencer berusaha untuk keluar dari bias dan sentimen tertentu. Ia ingin menggambarkan bahwa betapa upaya mempertahankan ide dan kepentingan material cenderung mewarnai dan mendistorsikan persepsi seseorang dalam memahami realitas sosial. (Maliki, 2003).

\section{Emile Durkheim}

Titik tekan kajian Durkheim berlwanan dengan kajian dari Spencer bahwa individu dibentuk oleh masyarakat. Asumsi yang paling fundamental dalam pandangan Durkheim gejala sosial yang riil dan mempengaruhi kesadaran individu serta perilakunya dan berbeda dari karakteristik psikologi, biologi 
atau karakteristik individu yang lain. Gejala sosial atau fakta sosial yang riil dapat dipelajari dengan metode-metode empirik, yang memungkinkan tentang ilmu yang membahas masyarakat dapat dikembangkan (Jonshon, 1994). Durkheim memberikan sifat yang ada pada kesadaran kolektif yakni eksterior dan constraint, eksterior berada di luar individu yang masuk ke dalam individu dalam perwujudan sebagai aturan moral, agama dan yang lain. Sedangkan untuk constraint merupakan kesadaran yang bersifat memaksa. Kesadaran kolektif merupakan konsensus masyarakat yang mengatur hubungan sosial diantara masyarakat yang bersangkutan (Siahaan, 1986).

Kajian dalam ilmu sosial menurut Durkheim melakukan pembacaan terhadap realitas sosial dengan cara makro dengan menggunakan pendekatan fakta sosial. Fakta sosial suatu kenyataan yang memiliki karakteristik khusus yakni mengandung tata cara bertindak berfikir dan merasakan yang berada diluar individu yang ditamankan dengan kekuatan koersif. Fakta sosial merupakan cara bertindak, yang memiliki ciri-ciri gejala empirik, yang terukur eksternal, menyebar dan menekan. Kekuatan koersif merupakan kekuatan untuk menekan individu. Fakta sosial dapat dikaji melalui data diluar pikiran manusia, studi yang trukur dan emirik merupakan koreksi terhadap Comte dan Spencer. Fakta sosial merupakan kumpulan fakta individu, tetapi kemudian diungkapkan dalam suatu angka sosial. Angka merupakan representasi individu yang berkumpul sehingga menjadi plural (Maliki, 2003).

\section{Vilfredo Pareto}

Menurut Pareto dalam ilmu sosial bahwa ia mengamati fakta-fakta atau kenyataan secara objektif melalui penalaran logika. Observasi atau eksperimentasi terhadap fakta tidak membutuhkan pra-anggapan yang diwarnai suatu prasangka. 
Dalam logical experimental ada dua elemen dasar yakni yang dinamakan logical reasoning dan observation of the fact. Teori sosial yang ada selama ini bersifat dogmatis, metafisis, non logis, absolut dan bersifat moral saja. Tindakan bagi Pareto merupakan didasarkan pada logis. Masyarakat baginya merupakan fenomena ketergantungan, karena faktor yang telah dibentuk oleh masyarakat faktor yang saling bergantung dan saling mempengaruhi. Ilmu sosial baginya merupakan yang mempelajari uniformitas dalam masyarakat (Siahaan, 1986). Pareto mempercayai bahwa konsep ekulibrium sangat berguna dalam memahami kehidupan sosial yang kompleks. Ia mencoba menjelaskan pertautan variabel yang diyakini masing-masing menyumbangkan keseimbangan dalam masyarakat (Maliki, 2003).

Dalam ilmu sosial positivistik bersifat bebas nilai, objektif dan dalam perubahan yang terjadi dalam masyarakat memandangnya pada evolusi sosial. Perubahan yang terjadi dengan evolusi tersebut yang menekankan pada ekulibrium ini, sehingga dalam ilmu sosial positivistik lebih bersifat status quo dan tidak peka perubahan. Pandangan yang digunakan dalam ilmu ini menggunakan pendekatan makro melihat realitas sosial dengan menggunakan sistem dan bagaiman individu terbentuk oleh sistem sehingga bersifat deterministik.

Asumsi dasar dalam ilmu sosial positivistik memandang masyarakat bagaikan sebuah sistem organisme dimana satu yang lain saling berkaitan dan terdiri dari berbagai macam struktur dan menjalankan fungsinya masing-masing. Jika diturunkan dalam metodologi penelitian maka tujuan dari penelitian untuk menjelaskan dan memaparkan tentang gejala sosial, penelitian harus objektif terukur, bebas nilai, dan peneliti bersifat netral. Penelitian ini dapat digunakan untuk generalisasi terhadap persolan yang lain. Metode 
penelitian merupakan penelitian kuantitatif, denan menggunakan pencarian atau melalui angket dan kuesioner.

\section{Ilmu Sosial Kontruktivisme}

Paradigma konstruktivis dalam ilmu sosial merupakan sebagai kritik terhadap ilmu sosial positivistik. Menurut paradigma ini, yang menyatakan bahwa realitas sosial secara ontologis memiliki bentuk yang bermacam-macam merupakan konstruksi mental, berdasarkan pengalman sosial, bersifat lokal dan spesifik dan tergantung pada orang yang melakukan. Realitas sosial yang diamati seseorang tidak dapat digeneralisir pada semua orang yang biasa dilakukan oleh kaum positivistik.

Epistemologi antara pengamatan dan objek dalam aliran ini bersifat satu kesatuan, subjektif dan merupakan hasil perpaduan interaksi antara keduanya. Aliran ini menggunakan metodologi hermeneutik dan sialektis dalam proses mencapai kebenaran. Metode yang pertama kali dilakukan melalui identifikasi kebenaran atau konstruksi pendapat orang-perorang, kemudian membandingkan dan menyilangkan pendapat dari orang sehingga tercapai suatu konsensus tetang kebenaran yang telah disepakati bersama (Salim, 2001).

\section{Max Weber}

Weber mengajukan bahwa dalam ilmu sosial yang dipakai menggunakan pendekatan verstehende. Ia melihat ilmu sosial berusaha untuk memahami tindakan-tindakan sosial dan menguraikannya dengan menerangkan sebab-sebab tindakan tersebut. Yang menjadi kajian pokok dalam ilmu ini menurutnya bukanlah bentuk subtansial kehidupan masyarakat maupun nilai objektif dari tindakan, melainkan semata-mata arti yang nyata dari tindakan perorangan yang timbul dari alasan alasan subjektif. Verstehende merupakan 
motode pendekatan yang berusaha untuk mengerti makna yang mendasari dan mengintari peristiwa sosial histories (Siahaan, 1986). Weber melihat bahwa individu yang memberikan pengaruh pada masyarakat tetapi dengan beberapa catatan bahwa tindakan sosial individu berhubungan dengan rasionalitas (Maliki, 2003).

Perbedaan antara Weber dan Durkheim tentang kenyataan sosial. Bagi Durkheim bahwa ilmu sosial mempelajari fakta sosial yang bersifat eksternal, memaksa individu. Kenyataan sosial bagi Durkheim sebagai situasi yang mengtasi individu berada dalam suatu tingkatan yang bebas. Sedangkan bagi Weber keyataan sosial merupakan sesuatu yang didasarkan pada motivasi individu dan tindakan-tindakan sosial. Durkheim memiliki pandangan berhubungan dengan realisme sosial, melihat masyarakat sebagai sautan yang riil, berada secara terlepas dari individu yang kemudian masuk di dalamnya menurut prinsip-prinsip yang khas, tidak mencerminkan individu-individu yang sadar. Teori ini membandingkan masyarakat sebagai bentuk organisme biologis dalam artian dalam menilai masyarakat merupakan suatu kenyataan yang lenih dari sekedar jumlah bagiannya. Pandangan Weber bersifat subjekif dan tujuannya untuk masuk kedalam arti subjektif yang berhungan dengan kategori interaksi manusia. (Jonshon, 1986).

Pemikiran Weber dari tindakan sosial dan metode verstehende berkembang dibawa oleh beberapa ilmuan menjadi tradisi konstruktivisme. Tradisi ini dikembangkan oleh Peter L. Berger dan Thomas Luckman, mereka berangkat dari manusia mengkonstruksi realitas sosial dari perfektif subjektif dapat berubah menjadi objektif.

Aliran konstruktivis merupakan respon terhadap positivistik dan memiliki sifat yang sama dengan positivistik, sedangkan yang membedakan objek kajiannya sebagai awal dalam 
memandang realitas sosial. Positivistik berangkat dari sistem dan struktur sosial sedangakan konstruktivis berangkat dari subjek yang bermakna dan memberikan makna dalam realitas sosial. Jika mau diturunkan dalam metodologi penelitian menjadi tujuan ilmu sosial ini memahami realitas sosial, ilmu bersifat neutral dan bebas nilai. Asumsi dasar yang digunakan bahwa manusia sebagai mahluk yang berkesadaran. Penelitian yang dipakai merupakan penelitian kualitatif dengan metode pencarian data dengan wawancara dan observasi. Dalam memandang masyarakat merupakan realitas yang beragam dan memiliki keunikatan tersendiri, sehingga dari hasil penelitian yang didapatkan tidak boleh untuk menggeneralkan pada objek yang lain.

\section{Ilmu Sosial Kritis}

Teori sosial ini merupakan upaya pengkrtisan terhadap the father dari filsafat Jerman dan mengkritisi pemikiran Marx yang telah menjadi ideologi bukannya ilmu. Marx yang telah menjadi ideologi dapat dilihat pada Negara komunis sehingga ajaran Marx membatu dan tidak besifat transformatif. Ritzer mencoba memetakan tentang sasaran kritik para pemikir dari mazhab Frankfurt yakni ada lima macam, pertama kritik terhadap dominasi ekonomi, kritik terhadap sosiologi pada intinya mengatakan bahwa sosiologi bukanlah sekedar ilmu atau metode sendiri tetapi harus dapat mentransformasikan struktur sosial dan membantu manusia keluar dari tekanan struktur, kritik filsafat positivistik yang memandang manusia sebagai objek (alam) dan tidak tanggap terhadap perubahan, kritik terhadap masyarakat modern yang telah dikuasai oleh revolusi budaya, kritik budaya (birokrasi) yang menyebabkan masyarakat dibatasi oleh mekanisme adminitrasi, dan melahirkan budaya semu yang melahirkan represifitas struktur yang melumpuhkan manusia. 
Munculnya pemikiran Mazhab Frankfurt merupakan melawan krisis pada waktu saat itu, ia kecewa terhadap pengaruh filsafat positivistik yang melahirkan perfektif objektivistik dan pengaruhnya masuk ke dalam seluruh disiplin ilmu pengetahuan. Bagi mereka, dengan pemikiran yang telah diiajukan oleh positivistik telah melahirkan wawasan dan cara pemikiran jangka pendek. Kenyakinan positivisme telah menimbulkan krisis, oleh karena itu ia menawarkan pemikiran alternatif "teori kritis". Akar pemikiran Mazhab ini dapat ditelusuri dari Marx, Hegel yang telah memberikan banyak ilustrasi dan memberikan pencerahan.

Analisis yang digunakan frankfurt menggunakan dua proporsi yang utama. Pertama pemikiran seseorang merupakan produk masyarakat dimana ia hidup. Pemikiran manusia terbentuk secara sosial, maka tidak mungkin orang mencapai pengetahuan dan kesimpulan objektif, bebas dari pengaruh perkembangan zaman dan pola-pola konseptual yang ada dimana manusia hidup. Kedua, ilmuan dan intelektual tidak dapat objektif, mencoba bersikap bebas nilai dalam membangun perfektif pemikirannya.

Kata kunci kritik merupakan upaya untuk memahami dalam teori kritis, kritik dalam teori ini merupakan mengupayakan suapaya teori bersifat emansipatoris tentang kebudayaan dan masyarakat modern. Kritik-kritik mereka diupayakan dalam berbagai bidang kehidupan masyarakat modern, seperti seni, ekonomi, ilmu pengetahuan, politik dan kebudayaan yang telah diselubungi oleh ideologi yang telah menguntungkan pihak-pihak tertentu dan sekaligus mengasingkan manusia dalam kehidupan masyarakat. Kata kritik berakar dalam tradisi filsafat itu sendiri dan kata tersebut sudah dipakai sejak zaman pencerahan. 
Kritik merupakan refleksi diri atas rintangan-rintangan, tekanan-tekanan dan kontradiksi yang menghambat proses pembentukan diri rasio dalam sejarah. Kritik juga merupakan refleksi atas proses menjadi sadar atau refleksi tentang asal-usul tentang kesadaran.

\begin{tabular}{|c|c|c|c|}
\hline Parameter & Dimensi kerja & Dimensi komunikasi & $\begin{array}{l}\text { Dimensi } \\
\text { kekuasaan }\end{array}$ \\
\hline Kepentingan & Teknis & Praktis & Emansipatoris \\
\hline Pengetahuan & Informasi & Interpretasi & Analitis \\
\hline Tindakan & $\begin{array}{l}\text { Tindakan- } \\
\text { rasional- } \\
\text { bertujuan }\end{array}$ & $\begin{array}{l}\text { Tindakan } \\
\text { komunikatif }\end{array}$ & $\begin{array}{l}\text { Tindakan } \\
\text { revolusioner- } \\
\text { emansipatoris }\end{array}$ \\
\hline $\begin{array}{l}\text { Ungkapan } \\
\text { lingustik }\end{array}$ & $\begin{array}{l}\text { Proposisi- } \\
\text { proposisi deduktif } \\
\text { nomologis } \\
\text { (monologal) }\end{array}$ & $\begin{array}{l}\text { Bahasa sehari-hari, } \\
\text { language game, } \\
\text { ungkapan-ungkapan } \\
\text { dialogal }\end{array}$ & $\begin{array}{l}\text { Pembicaraan } \\
\text { emansipatoris }\end{array}$ \\
\hline Metodologi & Empiris-analitis & $\begin{array}{l}\text { Historis- } \\
\text { hermeneutis }\end{array}$ & Refleksi-diri \\
\hline $\begin{array}{l}\text { Sistematika } \\
\text { metodis }\end{array}$ & $\begin{array}{l}\text { Ilmu empiris- } \\
\text { analitis (ilmu } \\
\text { pengetahuan } \\
\text { alam) }\end{array}$ & $\begin{array}{l}\text { Ilmu histories- } \\
\text { hermeneutis (ilmu- } \\
\text { ilmu pengetahuan } \\
\text { sosial budaya) }\end{array}$ & Ilmu-ilmu kritis \\
\hline
\end{tabular}

Tabel 1. Matrik Ilmu Sosial Kritis

Ilmu sosial kritis jika mau diderivasikan dalam metodologi penelitian, merupakan suatu ilmu yang emansipatoris dan untuk melakukan transformasi sosial. Ilmu ini tidak bebas nilai, berpihak kepada kemanusiaan dan melakukan pemberdayaan sehingga tercipta masyarakat yang berkeadilan. 


\section{Teori-Teori Sosial dalam Sosiologi}

\section{Teori Konflik}

\section{Teori Konflik Menurut Karl Marx (1818- 1883)}

Teori konflik Karl Marx didasarkan pada pemilikan saranasarana produksi sebagai unsur pokok pemisahan kelas dalam masyarakat.

Marx mengajukan konsepsi mendasar tentang masyarakat kelas dan perjuangannya. Marx tidak mendefinisikan kelas secara panjang lebar tetapi ia menunjukkan bahwa dalam masyarakat, pada abad ke- 19 di Eropa di mana dia hidup, terdiri dari kelas pemilik modal (borjuis) dan kelas pekerja miskin sebagai kelas proletar. Kedua kelas ini berada dalam suatu struktur sosial hirarkis, kaum borjuis melakukan eksploitasi terhadap kaum proletar dalam proses produksi. Eksploitasi ini akan terus berjalan selama kesadaran semu eksis (false consiousness) dalam diri proletar, yaitu berupa rasa menyerah diri, menerima keadaan apa adanya tetap terjaga.

Ketegangan hubungan antara kaum proletar dan kaum borjuis mendorong terbentuknya gerakan sosial besar, yaitu revolusi. Ketegangan tersebut terjadi jika kaum proletar telah sadar akan eksploitasi kaum borjuis terhadap mereka.

\section{Teori Konflik Menurut Lewis A. Coser}

Konflik dapat merupakan proses yang bersifat instrumental dalam pembentukan, penyatuan dan pemeliharaan struktur sosial. Konflik dapat menempatkan dan menjaga garis batas antara dua atau lebih kelompok. Konflik dengan kelompok lain dapat memperkuat kembali identitas kelompok dan melindunginya agar tidak lebur ke dalam dunia sosial sekelilingnya. 
Seluruh fungsi positif konflik tersebut dapat dilihat dalam ilustrasi suatu kelompok yang sedang mengalami konflik dengan kelompok lain. Misalnya, pengesahan pemisahan gereja kaum tradisional (yang memepertahankan praktekpraktek ajaran katolik pra-Konsili Vatican II) dan gereja Anglo- Katolik (yang berpisah dengan gereja Episcopal mengenai masalah pentahbisan wanita). Perang yang terjadi bertahun-tahun yang terjadi di Timur Tengah telah memperkuat identitas kelompok Negara Arab dan Israel.

Coser (1956, hal. 41) melihat katup penyelamat berfungsi sebagai jalan ke luar yang meredakan permusuhan, yang tanpa itu hubungan-hubungan di antara pihak- pihak yang bertentangan akan semakin menajam. Katup Penyelamat (savety-value) ialah salah satu mekanisme khusus yang dapat dipakai untuk mempertahankan kelompok dari kemungkinan konflik sosial. Katup penyelamat merupakan sebuah institusi pengungkapan rasa tidak puas atas sebuah sistem atau struktur. Contohnya Badan perwakilan Mahasiswa atau panitia kesejahteraan Dosen. Lembaga tersebut membuat kegerahan yang berasal dari situasi konflik tersalur tanpa menghancurkan sistem tersebut.

Menurut Coser konflik dibagi menjadi dua, yaitu:

a. Konflik Realistis, berasal dari kekecewaan terhadap tuntutan- tuntutan khusus yang terjadi dalam hubungan dan dari perkiraan kemungkinan keuntungan para partisipan, dan yang ditujukan pada obyek yang dianggap mengecewakan. Contohnya para karyawan yang mogok kerja agar tuntutan mereka berupa kenaikan upah atau gaji dinaikkan.

b. Konflik Non-Realistis, konflik yang bukan berasal dari tujuan- tujuan saingan yang antagonis, tetapi dari kebutuhan untuk meredakan ketegangan, paling tidak dari salah satu pihak. Coser menjelaskan dalam 
masyarakat yang buta huruf pembasan dendam biasanya melalui ilmu gaib seperti teluh, santet dan lain- lain. Sebagaimana halnya masyarakat maju melakukan pengkambinghitaman sebagai pengganti ketidakmampuan melawan kelompok yang seharusnya menjadi lawan mereka.

\section{Teori Konflik Menurut Ralf Dahrendorf}

Teori konflik Ralf Dahrendorf merupakan separuh penerimaan, separuh penolakan, serta modifikasi teori sosiologi Karl Marx. Pendapat Dahrendorf, secara empiris menjelaskan pertentangan kelompok mungkin paling mudah di analisa bila dilihat sebagai pertentangan mengenai legitimasi hubungan-hubungan kekuasaan. Dalam setiap asosiasi, kepentingan kelompok penguasa merupakan nilainilai yang merupakan ideologi keabsahan kekuasannya, sementara kepentingan-kepentingan kelompok bawah melahirkan ancaman bagi ideologi ini serta hubunganhubungan sosial yang terkandung di dalamnya.

Misalnya kasus kelompok minoritas yang pada tahun 1960an kesadarannya telah memuncak, antara lain termasuk kelompok- kelompok kulit hitam, wanita, suku Indian dan Chicanos. Kelompok wanita sebelum tahun 1960-an merupakan kelompok semu yang ditolak oleh kekuasan di sebagian besar struktur sosial di mana mereka berpartisipasi. Pada pertengahan tahun 1960-an muncul kesadaran kaum wanita untuk menyamakan derajatnya dengan kaum laki-laki yang kemudian diikuti oleh perkembangan kelompok yang memperjuangkan kebebasan wanita.

\section{Teori Fungsional - Struktural}

Teori Fungsional-struktural adalah sesuatu yang penting dan sangat bermanfaat dalam suatu kajian tentang analisa 
masalah sosial. Hal ini disebabkan karena studi struktur dan fungsi masyarakat merupakan sebuah masalah sosiologis yang telah menembus karya-karya para pelopor ilmu sosiologi dan para ahli teori kontemporer.

Pokok-pokok para ahli yang telah banyak merumuskan dan mendiskusikan hal ini telah menuangkan berbagai ide dan gagasan dalam mencari paradigma tentang teori ini, sebut saja George Ritzer, Margaret M. Poloma, dan Turner. Drs. Soetomo mengatakan apabila ditelusuri dari paradigma yang digunakan, maka teori ini dikembangkan dari paradigma fakta sosial. Tampilnya paradigma ini merupakan usaha sosiologi sebagai cabang ilmu pengetahuan yang baru lahir agar mempunyai kedudukan sebagai cabang ilmu yang berdiri sendiri.

Secara garis besar fakta sosial yang menjadi pusat perhatian sosiologi terdiri atas dua tipe yaitu struktur sosial dan pranata sosial. Menurut teori fungsional struktural, struktur sosial dan pranata sosial tersebut berada dalam suatu sistem sosial yang berdiri atas bagian-bagian atau elemen-elemen yang saling berkaitan dan menyatu dalam keseimbangan.

Dengan demikian dapat dikatakan bahwa teori ini (fungsional-struktural) menekankan kepada keteraturan dan mengabaikan konflik dan perubahan-perubahan dalam masyarakat. Asumsi dasarnya adalah bahwa setiap struktur dalam sistem sosial, fungsional terhadap yang lain, sebaliknya kalau tidak fungsional maka struktur itu tidak akan ada atau hilang dengan sendirinya. Dalam proses lebih lanjut, teori inipun kemudian berkembang sesuai perkembangan pemikiran dari para penganutnya.

Emile Durkheim, seorang sosiolog Perancis menganggap bahwa adanya teori fungsionalisme-struktural merupakan suatu yang 'berbeda', hal ini disebabkan karena Durkheim 
melihat masyarakat modern sebagai keseluruhan organisasi yang memiliki realitas tersendiri. Keseluruhan tersebut menurut Durkheim memiliki seperangkat kebutuhan atau fungsi-fungsi tertentu yang harus dipenuhi oleh bagianbagian yang menjadi anggotanya agar dalam keadaan normal, tetap langgeng. Bilamana kebutuhan tertentu tadi tidak dipenuhi maka akan berkembang suatu keadaan yang bersifat "patologis". Para fungsionalis kontemporer menyebut keadaan normal sebagai ekuilibrium, atau sebagai suatu sistem yang seimbang, sedang keadaan patologis menunjuk pada ketidakseimabangan atau perubahan sosial.

Robert K. Merton, sebagai seorang yang mungkin dianggap lebih dari ahli teori lainnya telah mengembangkan pernyataan mendasar dan jelas tentang teori-teori fungsionalisme, Merton adalah seorang pendukung yang mengajukan tuntutan lebih terbatas bagi perspektif ini. Mengakui bahwa pendekatan ini (fungsional-struktural) telah membawa kemajuan bagi pengetahuan sosiologis.

Merton telah mengutip tiga postulat yang ia kutip dari analisa fungsional dan disempurnakannya, diantaranya ialah:

a. Postulat pertama, adalah kesatuan fungsional masyarakat yang dapat dibatasi sebagai suatu keadaan dimana seluruh bagian dari sistem sosial bekerjasama dalam suatu tingkatan keselarasan atau konsistensi internal yang memadai, tanpa menghasilkan konflik berkepanjangan yang tidak dapat diatasi atau diatur. Atas postulat ini Merton memberikan koreksi bahwa kesatuan fungsional yang sempurna dari satu masyarakat adalah bertentangan dengan fakta. Hal ini disebabkan karena dalam kenyataannya dapat terjadi sesuatu yang fungsional bagi satu kelompok, tetapi dapat pula bersifat disfungsional bagi kelompok yang lain. 
b. Postulat kedua, yaitu fungionalisme universal yang menganggap bahwa seluruh bentuk sosial dan kebudayaan yang sudah baku memiliki fungsi-fungsi positif. Terhadap postulat ini dikatakan bahwa sebetulnya di samping fungsi positif dari sistem sosial terdapat juga dwifungsi. Beberapa perilaku sosial dapat dikategorikan kedalam bentuk atau sifat disfungsi ini. Dengan demikian dalam analisis keduanya harus dipertimbangkan.

c. Postulat ketiga, yaitu indispensability yang menyatakan bahwa dalam setiap tipe peradaban, setiap kebiasaan, ide, objek materiil dan kepercayaan memenuhi beberapa fungsi penting, memiliki sejumlah tugas yang harus dijalankan dan merupakan bagian penting yang tidak dapat dipisahkan dalam kegiatan sistem sebagai keseluruhan. Menurut Merton, postulat yang kertiga ini masih kabur (dalam artian tak memiliki kejelasan), belum jelas apakah suatu fungsi merupakan keharusan.

\section{Pengaruh Teori Fungsional Struktural dalam Kehidupan Sosial}

Talcott Parsons dalam menguraikan teori ini menjadi subsistem yang berkaitan menjelaskan bahwa diantara hubungan fungsional-struktural cenderung memiliki empat tekanan yang berbeda dan terorganisir secara simbolis:

a. Pencarian pemuasan psikis

b. Kepentingan dalam menguraikan pengertian-pengertian simbolis

c. Kebutuhan untuk beradaptasi dengan lingkungan organisfisis, dan

d. Usaha untuk berhubungan dengan anggota-anggota makhluk manusia lainnya. 
Sebaliknya masing-masing sub-sistem itu, harus memiliki empat prasyarat fungsional yang harus mereka adakan sehingga bisa diklasifikasikan sebagai suatu sistem. Parsons menekankan saling ketergantungan masing-masing sistem itu ketika dia menyatakan: "secara konkrit, setiap sistem empiris mencakup keseluruhan, dengan demikian tidak ada individu kongkrit yang tidak merupakan sebuah organisme, kepribadian, anggota dan sistem sosial, dan peserta dalam sistem kultural “.

Walaupun fungsionalisme struktural memiliki banyak pemuka yang tidak selalu harus merupakan ahli-ahli pemikir teori, akan tetapi paham ini benar-benar berpendapat bahwa sosiologi adalah merupakan suatu studi tentang strukturstruktur sosial sebagai unit-unit yang terbentuk atas bagianbagian yang saling tergantung.

Fungsionalisme struktural sering menggunakan konsep sistem ketika membahas struktur atau lembaga sosial. Sistem ialah organisasi dari keseluruhan bagian-bagian yang saling tergantung. Ilustrasinya bisa dilihat dari sistem listrik, sistem pernapasan, atau sistem sosial. Yang mengartikan bahwa fungionalisme struktural terdiri dari bagian yang sesuai, rapi, teratur, dan saling bergantung. Seperti layaknya sebuah sistem, maka struktur yang terdapat di masyarakat akan memiliki kemungkinan untuk selalu dapat berubah. Karena sistem cenderung ke arah keseimbangan maka perubahan tersebut selalu merupakan proses yang terjadi secara perlahan hingga mencapai posisi yang seimbang dan hal itu akan terus berjalan seiring dengan perkembangan kehidupan manusia.

\section{Teori Interaksi Simbolik}

Tokoh teori interaksi simbolik antara lain: George Herbert Mend, Herbert Blumer, Wiliam James, Charles Horton Cooley. Teori interaksi simbolik menyatakan bahwa interaksi sosial 
adalah interaksi symbol. Manusia berinteraksi dengan yang lain dengan cara menyampaikan simbol yang lain memberi makna atas simbol tersebut.

Asumsi-asumsi:

a. Masyarakat terdiri dari manusia yang berinteraksi melalui tindakan bersama dan membentuk organisasi.

b. Interaksi simbolik mencangkup pernafsiran tindakan. Interaksi non simbolik hanyalah mencangkup stimulus respon yang sederhana.

\section{Pelapisan Sosial /Stratifikasi Sosial}

Pelapisan sosial adalah perbedaan tinggi rendah kedudukan seseorang/sekelompok orang dibandingkan dengan sseseorang atau sekelompok orang lain dalam masyarakat. Pelapisan sosial dapat terjadi karena pengaruh berbagai kriteria, antara lain ekonomi, politik, sosial.

a. Sistem Pelapisan Sosial

Menurut status kependudukan asli atau pendatang misalnya di daerah Jawa dengan adanya cikal bakal yaitu orang yang merintis tinggal didaerah tersebut dan mempunyai keturunan di daerah tersebut, womg baku yaitu orang yang mempunyai saudara, tanah, dan lahir di daerah tersebut, pendatang yaitu orang yang membeli tanah dan membangun di daerah tersebut. Sedangkan di Sumatra Utara ada yang disebut dengan Sipunta huta/bangsa tanah yaitu keturunan nenek moyang dan penduduk pendatang.

b. Diferensiasi Sosial

Diferensiasi sosial ialah perbedaan sosial dalam masyarakat secara horisontal. Bentuk diferensiasi sosial yaitu diferensiasi jenis kelamin, diferensiasi agama, diferensiasi profesi dan sebagainya. 


\section{Teori Pertukaran Sosial (Sosial Exchange Theory)}

Teori pertukaran sosial ini didasarkan pada pemikiran bahwa seseorang dapat mencapai suatu pengertian mengenai sifat kompleks dari kelompok dengan mengkaji hubungan di antara dua orang (dyadic relationship). Suatu kelompok dipertimbangkan untuk menjadi sebuah kumpulan dari hubungan antara dua partisipan tersebut.

Perumusan tersebut mengasumsikan bahwa interaksi manusia melibatkan pertukaran barang dan jasa, dan bahwa biaya (cost) dan imbalan (reward) dipahami dalam situasi yang akan disajikan untuk mendapatkan respons dari individu-individu selama berinteraksi sosial. Jika imbalan dirasakan tidak cukup atau lebih banyak dari biaya, maka interaksi kelompokkan diakhiri, atau individu-individu yang terlibat akan mengubah perilaku mereka untuk melindungi imbalan apapun yang mereka cari. Pendekatan pertukaran sosial ini penting karena berusaha menjelaskan fenomena kelompok dalam lingkup konsep-konsep ekonomi dan perilaku mengenai biaya dan imbalan. 


\section{BAB III \\ MASALAH \& KONFLIK SOSIAL}




\section{A. Masalah Sosial}

Terdapat beberapa definisi dari masalah sosial menurut para ahli, yaitu:

1. Masalah atau problema adalah perbedaan antara das sollen (yang seharusnya, yang diinginkan, yang dicitacitakan, yang diharapkan) dengan das sein (yang nyata, yang terjadi). Dengan kata lain masalah adalah perbedaan antara yang ideal dan real, misalnya kita mencita-citakan masyarakat yang sejahtera, ternyata yang terjadi banyak masyarakat yang masih miskin.

2. Menurut Horton dan Leslie dalam Suharto (2000), masalah sosial adalah suatu kondisi yang dirasakan banyak orang yang tidak menyenangkan serta menuntut pemecahan aksi sosial secara kolektif.

3. Parillo yang di kutip Soetomo dalam Pengorganisasisan dan Pengembangan Masyarakat: empat komponen dalam memahami pengertian masalah sosial, yaitu:

a. Masalah itu bertahan untuk suatu periode tertentu.

b. Dirasakan dapat menyebabkan berbagai kerugian fisik atau mental, baik pada individu maupun masyarakat.

c. Merupakan pelanggaran terhadap nilai-nilai atau standar sosial dari satu atau beberapa sendi kehidupan masyarakat.

d. Menimbulkan kebutuhan akan pemecahan.

Masalah sosial merupakan persoalan yang timbul secara langsung atau bersumber langsung dari suatu kondisi maupun proses sosial antara lain:

1. Masalah sosial pertama (Primary Sosial Problem) adalah kondisi yang berpengaruh terhadap konsekuensi yang beragam dan bermacam-macam bagi masyarakat.

2. Masalah sosial kedua (Secondary Sosial Problem) adalah kondisi yang merugikan diakibatkan secara umum dari masalah sosial yang lebih berpengaruh dan pada gilirannya mengakibatkan masalah sosial tambahan. 
3. Masalah sosial ketiga (Tertiary Sosial Problem) adalah kondisi yang merugikan langsung maupun tidak langsung mengakibatkan masalah yang lebih dominan.

Masalah sosial yang dihadapi bangsa Indonesia yang cukup menonjol sebagai berikut:

- Kemiskinan

- Pengangguran

- Kejahatan

- Kenakalan anak dan remaja

- Penyalahgunaan narkoba

- Pornografi, pornoaksi, dan prostitusi

- Perjudian

- Perkosaan

- Ganguan kejiwaan

- Masalah bencana

- Keterlantaran anak

- Lanjut usia terlantar

- Masalah kecacatan

- Buruknya jaminan sosial

- Konflik sosial
- Kerusuhan sosial

- Kekerasan terhadap anak dan perempuan

- Masalah pengungsi

- Masalah HIV/AIDS

- Masalah diskriminasi dan ketidakadilan

- Masalah daerah kumuh

- Kondisi kesehatan masyarakat yang buruk

- Disharmonisasi sosial

- Menurunnya solidaritas sosial

- Stres, depresi, dan bunuh diri

- Disorganisasi keluarga

- Konflik Sosial

\section{B. Pengertian Konflik Sosial}

Menurut Lawang (1994), konflik diartikan sebagai perjuangan untuk memperoleh hal-hal yang langka seperti nilai, status, kekuasaan, dan sebagainya dimana tujuan mereka berkonflik itu tidak hanya memperoleh keuntungan tetapi juga untuk menundukkan pesaingnya. Konflik dapat diartikan sebagai benturan kekuatan dan kepentingan antara satu kelompok dengan kelompok lain dalam proses perebutan sumber-sumber 
kemasyarakatan (ekonomi, politik, sosial dan budaya) yang relatif terbatas.

Konflik dapat terjadi pada setiap individu dan kelompok dalam masyarakat, yang menuntut adanya menyelesaikan. Setiap orang sudah dapat dipastikan pernah mengalami konflik, tidak terkecuali Anda, baik konflik secara pribadi maupun kelompok. Konflik pribadi dapat terjadi antar individu atau dalam diri sendiri. Perbedaan pandangan atau kepentingan atau pendapat dapat menjadi pemicu bagi munculnya konflik pribadi. Konflik yang terjadi dalam diri individu dapat muncul manakala terdapat perbedaan antara idealisme yang dimilikinya dengan kenyataan.

Konflik yang terjadi antara individu dengan individu, misalnya konflik di antara sesama teman di sekolah. Konflik antara individu dengan kelompok, misalnya konflik antara seorang majikan dengan buruhnya. Sedangkan konflik antara kelompok dengan kelompok, misalnya para pedagang kaki lima dengan para petugas ketertiban. Konflik kelompok dapat terjadi manakala dua kelompok mengalami perbedaan kepentingan atau perbedaan pendapat.

Konflik yang tidak teratasi menjadi potensi laten bagi terjadinya disintegrasi sosial. Dalam tatanan kehidupan bermasyarakat, konflik merupakan proses sosial. Konflik merupakan salah satu fakta sosial yang berbeda dengan fakta individual. Menurut Durkheim, fakta sosial memiliki tiga karakteristik yakni: bersifat eksternal terhadap individu, bersifat memaksa individu yang berada dalam lingkungan sosialnya, dan bersifat umum yakni tersebar di masyarakat. Fakta sosial meliputi: norma, moral, kepercayaan, kebiasaan, pola berfikir, dan pendapat umum, yang dimiliki bersama oleh anggota masyarakat. Fakta sosial tersebut disebut representatif kolektif.

Apabila kita amati dan perhatikan berbagai gejala dan fenomena kehidupan sehari-hari, baik yang kita alami sendiri maupun melalui berbagai sumber informasi (seperti surat kabar, majalah, 
radio, TV dan lain-lain) tentang konflik, diperkirakan ada sejumlah pola konflik, yakni sebagai berikut:

1. Konflik internal di terjadi dalam suatu masyarakat lokal

2. Konflik antara masyarakat lokal dengan pemerintah daerah sendiri

3. Konflik masyarakat antar daerah, suku, agama, dan ras (SARA)

4. Konflik antar dua atau lebih pemerintah daerah

5. Konflik antara masyarakat lokal dengan pemerintah pusat sebagai penyelenggaraan negara

6. Konflik antara pemerintah daerah dengan pemerintah pusat

7. Konflik antar elit di pemerintah pusat yang berimbas pada atau diikuti oleh konflik masyarakat di tingkat lokal

Konflik merupakan proses sosial yang akan terus terjadi dalam diri manusia dan di dalam masyarakat, baik secara pribadi atau kelompok, dalam rangka perubahan untuk mencapai tujuan tertentu dengan cara menentang lawannya. Konflik dapat memicu terjadinya kekerasan yang biasanya ditandai oleh adanya kerusuhan, pengrusakan dan perkelahian. Kekerasan merupakan gejala yang muncul sebagai salah satu efek dari konflik. Tindakan kekerasan ini sering tidak jelas tujuannya, ada kalanya hanya untuk kesenangan belaka, ikut dengan orang lain karena takut disebut tidak memiliki rasa kebersamaan, atau karena ditumpangi oleh kepentingan-kepentingan tertentu yang sengaja menciptakan kekacauan, dan tidak lahir dari tuntutan-tuntutan kelompok yang menentang, serta pelakunya tidak memahami tindakan yang mereka lakukan.

Salah satu contoh konflik yang diakhiri dengan kekerasan dan tidak memiliki tujuan yang jelas, misalnya tawuran antar pelajar. Berbagai sebab yang memicu terjadinya tawuran tersebut beraneka ragam, akan tetapi tetap saja tujuannya tidak jelas, apa yang mereka (para pelajar) diperebutkan atau diperjuangkan. 
Biasanya pemicu tawuran antar pelajar hanya sepele, mungkin hanya kesalahan bicara atau olok-olok antar teman.

Taylor dan Hudson (dalam Syahbana, 1999), mengkategorikan lima indikator dalam menggambarkan intensitas konflik yang terjadi dalam masyarakat Indonesia. Kelima Indikator tersebut adalah sebagai berikut:

1. Demonstrasi (a protest demonstration).

Dewasa ini, demonstrasi menjadi fenomena sosial yang terjadi hampir setiap hari. Demonstrasi dilakukan oleh sejumlah orang yang memiliki kepedulian yang sama untuk melakukan protes melalui tindakan tanpa kekerasan. Protes tersebut diarahkan terhadap suatu rezim, pemerintah, atau pimpinan dari rezim atau pemerintah tersebut; atau terhadap ideologi, kebijaksanaan, dan tindakan baik yang sedang direncanakan maupun yang sudah dilaksanakan. Misalnya, demostrasi yang dilakukan oleh para guru terhadap rancangan undang-undang guru dan dosen.

2. Kerusuhan

Kerusuhan pada dasarnya sama dengan demonstrasi, namun memiliki perbedaan dalam pelaksanaannya. Demonstrasi adalah protes tanpa kekerasan sedangkan kerusuhan adalah

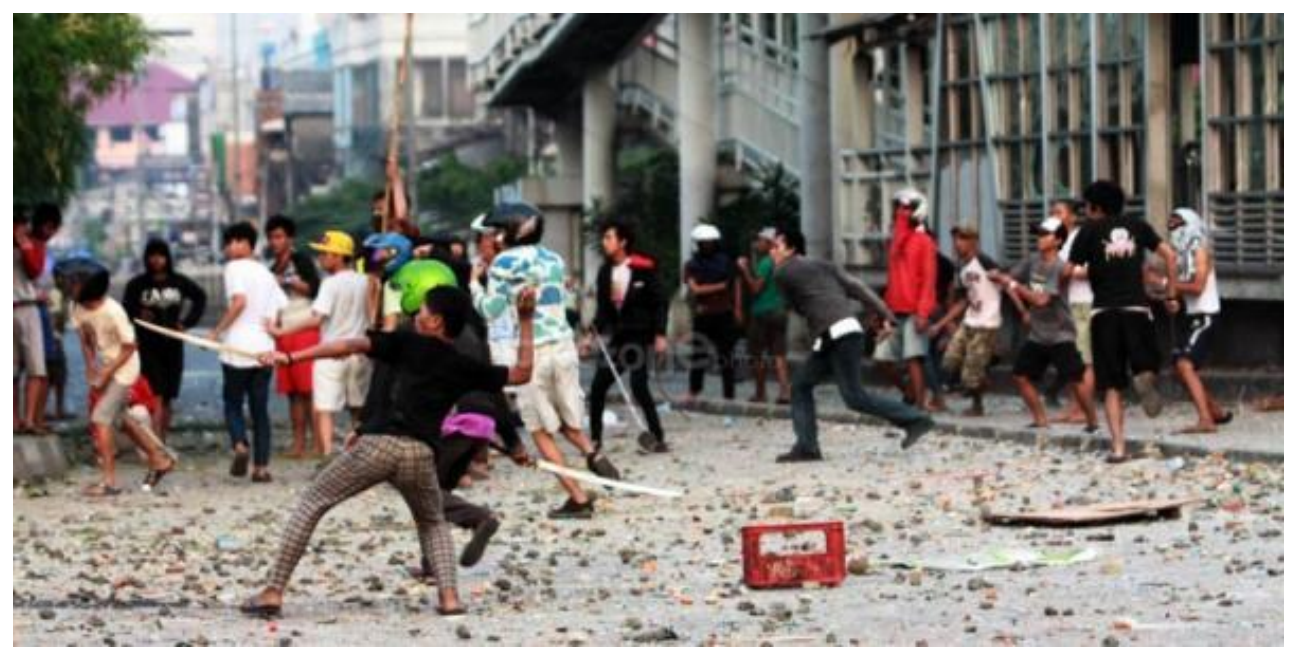


protes dengan penggunaan kekerasan yang mengarah pada tindakan anarkis.

Kerusuhan biasanya diikuti dengan pengrusakan barangbarang oleh para pelaku kerusuhan, yang seringkali menimbulkan penyiksaan dan pemukulan atas pelaku-pelaku kerusuhan tersebut. Penggunaan alat-alat pengendalian kerusuhan oleh para petugas keamanan di satu pihak, dan penggunaan berbagai macam senjata atau alat pemukul oleh para pelaku kerusuhan di lain pihak. Kerusuhan biasanya ditandai oleh spontanitas sebagai akibat dari suatu insiden dan perilaku kelompok yang kacau.

3. Serangan bersenjata (armed attack)

Serangan bersenjata adalah suatu tindakan kekerasan yang dilakukan oleh kelompok tertentu untuk suatu kepentingan dengan maksud melemahkan atau bahkan menghancurkan kelompok lain. Serangan bersenjatan ini seringkali ditandai oleh terjadinya pertumpahan darah, pergulatan fisik, atau pengrusakan barang-barang, sebagai akibat dari penggunaan alat atau senjata yang dipakai para penyerang.

4. Kematian

Kematian yang dimaksud adalah sebagai akibat dari adanya konflik yang direspon melalui demonstrasi, kerusuhan, maupun serangan bersenjata. Konflik yang menyebabkan munculnya kematian menunjukkan indikator tingkatan konflik yang memiliki intensitas tinggi.

\section{Faktor Penyebab Konflik Sosial}

Terjadinya konflik sosial umumnya melalui dua tahap, yaitu dimulai dari tahap keretakan sosial (disorganisasi) yang terus berlanjut ke tahap perpecahan (disintegrasi). Timbulnya gejala- 
gejala disorganisasi dan disintegrasi adalah akibat dari hal-hal berikut:

1. Ketidaksepahaman para anggota kelompok tentang tujuan masyarakat yang pada awalnya menjadi pedoman bersama.

2. Norma-norma sosial tidak membantu lagi anggota masyarakat dalam mencapai tujuan yang telah disepakati.

3. Kaidah-kaidah dalam kelompok yang dihayati oleh anggotanya bertentangan satu sama lain.

4. Sanksi menjadi lemah bahkan tidak dilaksanakan dengan konsekuen.

5. Tindakan anggota kelompok sudah bertentangan dengan norma-norma kelompok.

Penyebab konflik sangatlah kompleks yang dilatarbelakangi oleh berbagai dimensi dan peristiwa sosial. Konflik yang terjadi dalam masyarakat bisa berlatar belakang ekonomi, politik, kekuasaan, budaya, agama, dan kepentingan lainnya. Menurut DuBois dan Miley, sumber utama terjadinya konflik dalam masyarakat adalah adanya ketidakadilan sosial, diskriminasi terhadap hak-hak individu dan kelompok, dan tidak adanya penghargaan terhadap keberagaman.

Salah satu sebab terjadinya konflik ialah karena reaksi yang diberikan oleh dua orang/kelompok atau lebih dalam situasi yang sama berbeda-beda. Selain itu, konflik mudah terjadi apabila prasangka telah berlangsung lama. Menurut Gerungan (1966), prasangka sosial (social prejudice) terjadi karena:

1. Kurangnya pengetahuan dan pengertian tentang hidup pihak lain

2. Adanya kepentingan perseorangan atau golongan

3. Ketidakinsyafan akan kerugian dari akibat prasangka

Dalam sosiologi, konflik merupakan gambaran tentang terjadinya percekcokan, perselisihan, ketegangan atau pertentangan sebagai akibat dari perbedaan-perbedaan yang muncul dalam kehidupan 
masyarakat, baik perbedaan secara individual maupun perbedaan kelompok. Perbedaan tersebut dapat berupa perbedaan pendapat, pandangan, penafsiran, pemahaman, kepentingan atau perbedaan yang lebih luas dan umum, seperti perbedaan agama, ras, suku bangsa, bahasa, profesi, golongan politik dan kepercayaan. Sumber terjadinya konflik dalam kehidupan masyarakat dapat dikategorikan ke dalam lima faktor yaitu:

1. Faktor perbedaan individu dalam masyarakat

Perbedaan individu ini terjadi berdasarkan pada perbedaan antar anggota masyarakat secara orang perorangan, baik secara fisik dan mental maupun perbedaan material dan non-material. Perbedaan fisik lebih menekankan pada keadaan jasmaniah, misalnya rupa atau kecantikan, kesempurnaan indera dan bentuk tubuh. Perbedaan mental, misalnya kecakapan, kemampuan dan keterampilan, pendirian atau perasaa. Sedangkan perbedaan material lebih dicirikan dengan kepemilikan harta benda, misalnya orang kaya atau orang miskin, dan perbedaan non-material berkenaan dengan status sosial seseorang. Sehingga dari perbedaan-perbedaan tersebut menimbulkan pertikaian atau bentrokan di antara anggota masyarakat.

2. Perbedaan pola kebudayaan

Perbedaan yang terdapat antar daerah atau suku bangsa yang memiliki budaya yang berbeda, atau terdapat dalam satu daerah yang sama karena perbedaan paham, agama dan pandangan hidup. Sehingga dari perbedaan pola kebudayaan tersebut dapat melahirkan dan memperkuat entiment primordial yang dapat mengarah kepada terjadinya konflik antar golongan atau kelompok. Misalnya di daerah transmigrasi terjadi konflik antara kaum pendatang dengan penduduk asli. 
3. Perbedaan status sosial

Status sosial adalah kedudukan seseorang dalam kelompok atau masyarakat, yang untuk mendapatkannya ada yang bisa diusahakan (achieved status) dan ada pula status yang diperoleh dengan tanpa diusahakan (asdribed status). Status yang dapat diusahakan misalnya melalui pendidikan, orang yang memiliki tingkat pendidikan tinggi akan berada pada status sosial lebih tinggi dibandingkan dengan orang yang berpendidikan rendah, sedangkan status yang tanpa diusahakan dapat diperoleh melalui keturunan, seperti kasta dalam Agama Hindu atau kebangsawanan. Terdapatnya beragam kedudukan dalam masyarakat dapat menimbulkan perselisihan untuk mendapatkan kedudukan yang baik, terutama ascribed status.

4. Perbedaan kepentingan

Dalam memenuhi kebutuhan hidupnya, manusia memiliki kepentingan dan usaha yang berbeda, baik kebutuhan dasar maupun kebutuhan sosial, yang dapat menimbulkan pertentangan antar individu atau kelompok. Pada masyarakat nomaden sering terjadi pertikaian antar kelompok untuk mendapatkan daerah yang subur, sedangkan pada masyarakat industri sering terjadi perselisihan untuk mendapatkan bahan baku atau konsumen dan dalam aspek kehidupan politik terjadi perselisihan antar kelompok untuk mendapatkan partisipan. Jadi konflik yang terjadi karena perbedaan kepentingan dapat terjadi pada setiap masyarakat dengan berbagai tingkatannya.

5. Terjadinya perubahan sosial

Perubahan sosial dengan konflik terdapat hubungan karena perubahan sosial dapat terjadi akibat konflik sosial dan sebaliknya perubahan sosial dapat menimbulkan konflik. Masuknya unsur-unsur baru ke dalam suatu sistem sosial 
dapat menimbulkan perubahan sosial yang dapat dapat memicu terjadinya konflik apabila anggota masyarakat tidak seluruhnya menerima. Misalnya, penggunaan traktor pada bidang pertanian telah merubah struktur mata pencaharian dan melahirkan konflik antara petani dengan buruh tani (tenaga kerja).

Dari beberapa penjelasan di atas, dapat ditarik kesimpulan bahwa faktor-faktor yang menyebabkan terjadinya konflik di dalam masyarakat adalah sebagai berikut:

1. Adanya perbedaan kepribadian, pendirian, perasaan atau pendapat antar individu yang tidak mendapat toleransi di antara individu tersebut, sehingga perbedaan tersebut semakin meruncing dan mengakibatkan munculnya konflik pribadi.

2. Adanya perbedaan kebudayaan yang mempengaruhi perilaku dan pola berpikir sehingga dapat memicu lahirnya pertentangan antar kelompok atau antar masyarakat.

3. Adanya perbedaan kepentingan atau tujuan di antara individu atau kelompok, baik pada dimensi ekonomi dan budaya maupun politik dan keamanan.

4. Adanya perubahan sosial yang relatif cepat yang diikuti oleh adanya perubahan nilai atau sistem sosial. Hal ini akan menimbulkan perbedaan pendirian di antara warga masyarakat terhadap reorganisasi dari sistem nilai yang baru tersebut, sehingga memicu terjadinya disorganisasi sosial.

Dalam masyarakat, konflik selalu akan mewarnai fenomena sosial yang terefleksikan sebagai fakta sosial. Konflik sebagai proses sosial akan selalu berlangsung dalam kehidupan bermasyarakat karena masyarakat bersifat dinamis. Dinamika tersebut merupakan jawaban atas tuntutan kehidupan baik secara pribadi maupun kelompok. Hal ini sangat dipengaruhi oleh karakteristik masyarakat yang terdisi atas individu-individu yang diorganisasikan oleh norma dan nilai sosial. Anda sebagai 
mahasiswa dan kaum terpelajar tidak harus menjadikan konflik sebagai fobia dalam kehidupan, melainkan mencari solusi untuk mengorganisasikan konflik sebagai motivasi kemajuan diri dan masyarakat. Dalam hal ini, Anda memiliki kewajiban untuk mengembangkan diri menjadi pribadi yang memiliki kemampuan partisipatif. Anda harus memiliki kepedulian terhadap konflik, di antaranya sebagai sumber belajar dan sumber pemberdayaan diri yang dapat disumbangkan bagi masyarakat. Artinya, konflik akan selalu terjadi pada diri seseorang dan di dalam masyarakat, konflik tidak untuk dihindari melainkan diatasi karena konflik merupakan proses sosial.

\section{Permasalahan Baru di Era Globalisasi}

Seiring dengan perkembangan teknologi, internet menjadi salah satu hal yang tidak dapat lepas dalam kehidupan sehari-hari. Pada remaja atau yang lebih sering disebut dengan generasi milenial kini tidak dapat lepas dari sosial media dan media online lainnya. Perkembangan ini pula yang mempengaruhi bagaimana pola komunikasi yang pada awalnya hanya pada perorangan kini dapat diketahui dan dibaca oleh banyak orang.

Melalui sosial media dan media online serta blog, setiap orang dapat menulis konten ataupun meninggalkan komentar dengan mudah. Apabila tidak diiringi dengan media literasi serta semangat kebhinnekaan dalam diri maka pertikaian dalam dunia online dapat dengan mudah terjadi dan sering sekali ditemui. Salah satu permasalahan yang cukup menarik perhatian adalah dengan maraknya radikalisme di media sosial. 


\section{BAB IV \\ PELAKSANAAN PENGUATAN RESTORASI SOSIAL}


Sesuai dengan Peraturan Menteri Sosial Nomor 22 Tahun 2017 mengenai Restorasi Sosial, Penyelenggaraan Kesejahteraan Sosial adalah upaya yang terarah, terpadu, dan berkelanjutan yang dilakukan Pemerintah, pemerintah daerah, dan masyarakat dalam bentuk pelayanan sosial guna memenuhi kebutuhan dasar setiap warga negara, yang meliputi rehabilitasi sosial, jaminan sosial, pemberdayaan sosial, dan perlindungan sosial. Restorasi Sosial dilakukan dengan memberikan penguatan pada masyarakat guna menumbuhkan kembali nilai-nilai luhur budaya bangsa Indonesia.

\section{A. Sasaran Penguatan Restorasi Sosial}

Penguatan restorasi sosial diperuntukkan kepada masyarakat dan nilai-nilai kearifan lokal yang sudah memudar atau menurun. Penguatan Restorasi Sosial dilaksanakan secara mandiri dan terintegrasi di mulai dari tingkat desa/kelurahan/nama lain sampai dengan tingkat nasional. Penguatan Restorasi Sosial dilakukan oleh Pemerintah Pusat, pemerintah daerah, dan masyarakat. Penguatan Restorasi Sosial dilaksanakan secara terencana, terarah, terpadu, berkelanjutan, dan terkoordinasi.

Penguatan Restorasi Sosial yang dilakukan oleh Pemerintah Pusat, Pemerintah Daerah, dan masyarakat dilakukan dengan kegiatan tahapan:

1. Memetakan dan mengidentifikasi nilai-nilai kearifan lokal

Kearifan lokal dalam bahasa asing sering dikonsepsikan sebagai kebijakan setempat (local wisdom), pengetahuan setempat (local knowledge) atau kecerdasan setempat (local genious). Kearifan lokal juga dapat dimaknai sebuah pemikiran tentang hidup. Pemikiran tersebut dilandasi nalar jernih, budi yang baik, dan memuat hal-hal positif. Kearifan lokal dapat diterjemahkan sebagai karya akal budi, perasaan 
mendalam, tabiat, bentuk perangai, dan anjur- an untuk kemuliaan manusia (Wagiran, 2012). Kearifan adalah proses dan produk budaya manusia, dimanfaatkan untuk mempertahankan hidup.

Pemerintah daerah bersama masyarakat memetakan dan mengidentifikasi nilai-nilai kearifan lokal yang terdapat pada masing-masing daerah, seperti kebudayaan apa saja yang ada yang dapat terlihat pada kebiasaan masyarakat hingga adat istiadat setempat.

Beberapa kearifan lokal yang terdapat di Indonesia seperti yang dilansir oleh Pradana pada idntimes.com: Pesan yang ditulis melalui media sosial tidak terbatas dan dapat dibaca siapapun. Jangkauannya pun tidak terbatas di Indonesia tetapi juga dapat diakses di seluruh dunia. Oleh karena itu peran ideologi pancasila dalam masing-masing diri masyarakat menjadi salah satu kunci sebagai benteng dari tulisan pihak yang tidak bertanggung jawab dan rentan untuk memancing perpecahan bangsa. Implementasi nilainilai Pancasila dalam kehidupan sehari-hari harus terus dilaksanakan. Hal ini merupakan tanggung jawab bersama seluruh anak bangsa untuk mencegah berkembangnya paham-paham radikal, terutama pada generasi muda.

a. Sistem Sasi

Masyarakat Maluku dan Papua kekayaan laut untuk kehidupan sehari-hari. Oleh karena itu, masyarakat Maluku dan Papua bersikap tidak serakah dalam

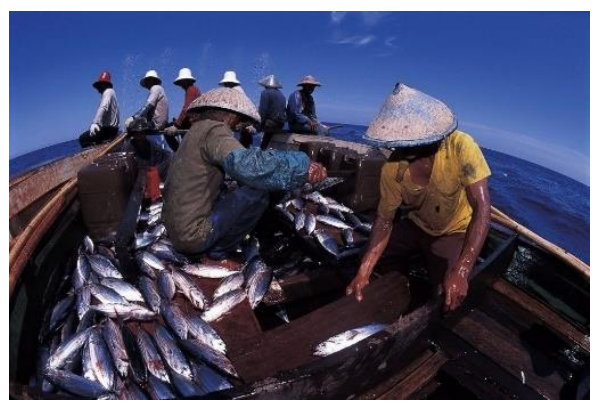
mengambil hasil laut kerena mereka memiliki sistem sasi. Sistem Sasi adalah pengaturan waktu bagi penduduk setempat untuk mengambil hasil laut di wilayah adatnya. 
Penduduk hanya boleh menangkap ikan pada saat-saat tertentu. Dengan demikian, flora dan fauna laut bisa memperbaharui diri dan berkembang biak dengan baik. Dengan menanamkan sistem sasi dalam proses penangkapan ikan, keberadaan ekosistem laut dapat tetap terjaga dengan baik.

b. Ilmu Tiga Hutan

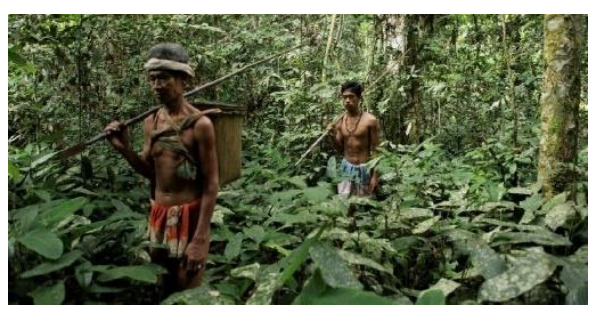

Suku Sakai di Riau menganggap bahwa hutan adalah harta yang harus dirawat sebaik-baiknya. Suku Sakai membagi wilayah hutan mereka menjadi tiga bagian yaitu hutan adat, hutan larangan, dan hutan perladangan. Di hutan adat, penduduk hanya boleh mengambil rotan, damar, dan madu lebah, tanpa menebang pohonnya. Sedangkan hutan larangan sama sekali tidak boleh diusik. Sementara hutan perladangan boleh ditebang untuk dijadikan ladang tapi tidak semua pohon boleh ditebang, misalnya pohon sialang yang menjadi tempat bersarangnya lebah madu.

Penduduk yang melanggar aturan akan dihukum, misalnya didenda atau diusir dari wilayahnya. Hukuman berlaku untuk semua orang, bahkan bathin atau kepala suku yang tertangkap melanggar aturan akan dicopot kedudukannya.

c. Ilmu Pamali

Pamali dalam bahasa Sunda berati tabu alias tidak boleh. Aturan ini tidak tertulis tapi sangat dipatuhi oleh masyarakat Kampung

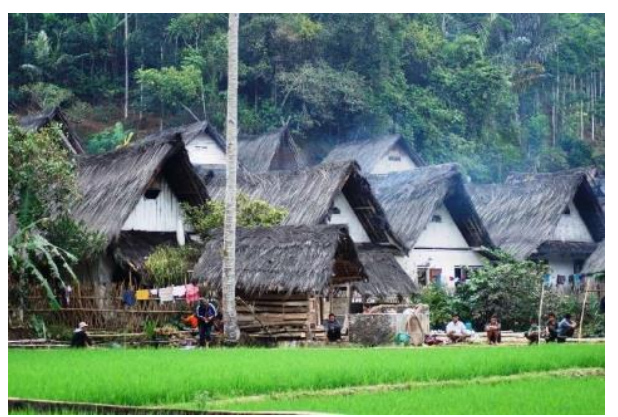


Naga di Tasikmalaya. Penduduk Kampung Naga percaya jika melanggar adat hidupnya tidak bakal selamat. Peraturan tersebut di antaranya tidak boleh mengusik Leuweng Larangan atau Hutan Larangan. Karenanya, penduduk membiarkan pohon tumbang di hutan sampai membusuk. Mereka juga tidak berani menangkap binatang di hutan. Ilmu Pamali membuat hutan mereka tetap lestari.

d. Ilmu Perladangan Gilir Balik

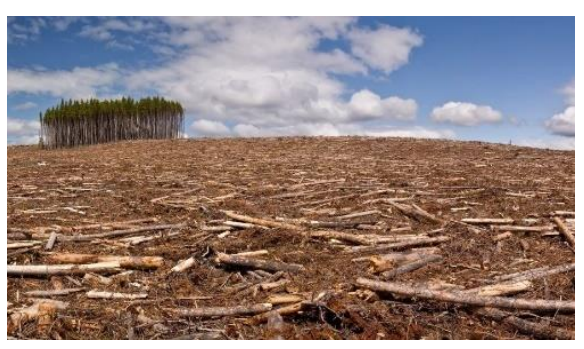

Suku Dayak Bantian di Kalimantan Timur menanam padi, sayuran, rotan, dan buah-buahan di hutan. Mereka menggunakan sistem perladangan gilir balik. Mereka membuka hutan untuk dijadikan ladang selama 2 tahun, setelah itu mereka mencari ladang baru dan membiarkan ladang lama menjadi hutan kembali. Begitu seterusnya dan tidak semua hutan boleh dijadikan ladang.

Ada pula wilayah hutan yang hanya boleh diambil hasilnya. Buah-buahan hutan yang tidak termakan oleh penduduk, dibiarkan di hutan agar dimakan oleh satwa liar.

e. Ilmu Pikukuh

Pikukuh bagi masyarakat Baduy di Banten adalah aturan yang harus ditaati oleh warganya dan oleh pengunjung yang datang. Aturan itu antara lain, dalam pertanian dilarang

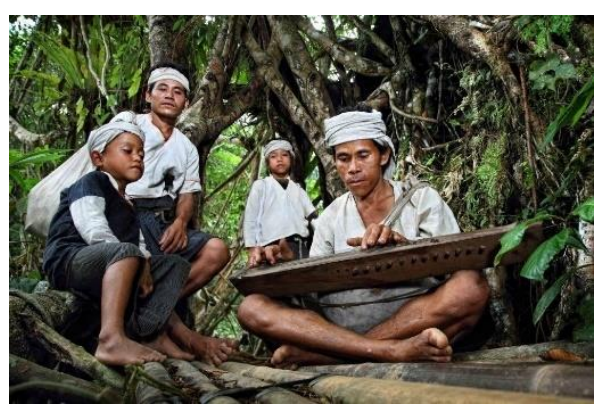
menggunakan teknologi kimia seperti pupuk buatan dan 
racun pemberantas hama. Penduduk juga dilarang menubai atau meracuni ikan di sungai, mandi memakai sabun, gosok gigi dengan pasta gigi, membuang kotoran di sembarang tempat, dan lain sebagainya. Pikukuh membuat masyarakat Baduy hidup berdampingan dengan alam. Mereka tidak mau mencemari alam dan berusaha menjaga kebersihan serta kemurnian alamnya.

Berdasarkan nilai kearifan lokal tersebut, masyarakat dapat hidup berdampingan. Tidak hanya sesama manusia namun juga kepada alam. Identifikasi dilakukan untuk melakukan pendataan kepada seluruh nilai kearifan lokal yang ada pada suatu daerah serta membaginya ke dalam katagori tertentu yang sesuai.

Oleh karena itu, peran masyarakat sangat dibutuhkan untuk bekerja sama bersama Pemerintah Daerah untuk mendata kembali. Nilai-nilai kearifan lokal ini kemudian diidentifikasi dan di data yang selanjutnya akan dilakukan penjajagan.

2. Pelaksanaan penjajagan

Setelah melakukan identifikasi nilai-nilai kearifan lokal, tahap selanjutnya yang dilakukan adalah melakukan penjajagan. Penjajagan disini merupakan tindak lanjut dari identifikasi nilai kearifan lokal untuk mengetahui lebih dalam dan lengkap tentang nilai kearifan lokal yang ada apakah dapat diaplikasikan secara luas kembali.

Pelaksanaan penjajagan dilakukan apabila masyarakat bersama Pemerintah Daerah dapat menilai kearifan lokal untuk kembali dilestarikan dalam bentuk diaplikasikan ke dalam kehidupan sehari-hari.

3. Seleksi dan identifikasi

Tahap yang dilakukan setelah penjajagan adalah seleksi dan identifikasi. Pada tahap ini, apabila dari proses penjajagan 
terdapat beberapa hal yang penting yang mulai terlupakan dan dianggap sebagai solusi untuk mengembalikan kepada tatanan yang sedia kala.

Proses seleksi dan identifikasi disesuaikan dengan permasalahan dan keadaan masyarakat di daerahnya masing-masing. Misalnya, pada masyarakat di daerah pesisir dengan sebagian masyarakatnya bermata pencaharian sebagai nelayan. Terdapat beberapa masalah terkait dengan tidak pahamnya masyarakat pada proses penangkapan ikan yang baik. Apabila masyarakat disuatu daerah mulai merasa ikan yang didapatkannya mulai berkurang dan kualitas menurun. Pada saat itu, dilakukan identifikasi permasalahan apa yang diterima dan dilakukan dalam proses penangkapan ikan yang dilakukan masyarakat setempat. Apabila banyak masyarakat yang menggunakan bom atau peralatan lain yang berbahaya tanpa mengetahui dampaknya kedepan disini perlunya peran Pemerintah Daerah bersama perwakilan masyarakat untuk bekerjasama melakukan pengenalan kembali mengenai proses sistem sasi.

Dari hal tersebut, dapat melakukan seleksi melalui identifikasi masalah yang ada pada daerah tersebut lebih terfokus pada permasalahan yang ada.

4. Menetapkan kesepakatan bersama

Setelah melakukan seleksi dan identifikasi, dilakukan

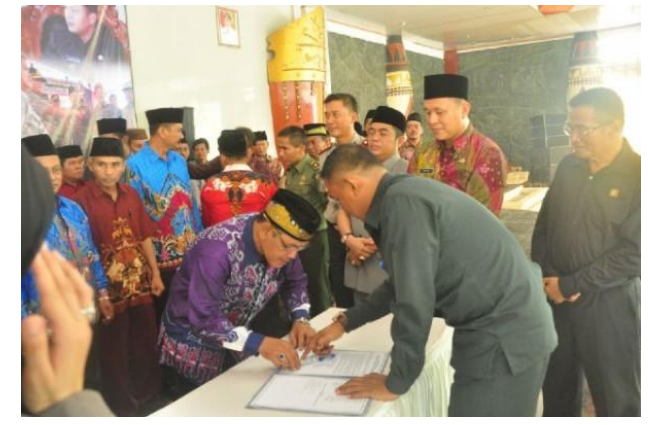
penetapan kesepakatan bersama. Kesepakatan ini dilakukan berdasarkan penyelesaian yang dilakukan untuk permasalahan yang ada yang disesuaikan dengan nilai-nilai kearifan lokal yang terdapat pada masyarakat 
tersebut. Misalnya pada studi kasus, desa pesisir yang mulai kehabisan stok ikan yang bermutu bagus.

Setelah mengetahui permasalahan yang dilakukan, tahap selanjutnya adalah menyepakati kebijakan bersama untuk seluruh kegiatan menangkap ikan harus menggunakan sistem sasi.

Hal tersebut dimana ikan-ikan kecil tidak ditangkap dan menjaga alam dengan tidak menggunakan peralatan yang membahayakan ekosistem dan biota laut disekitarnya. Selain itu, perlu juga disepakati apabila hal tersebut dilanggar, konsekuensi yang didapatkannya apa.

5. Menyusun rencana kerja

Tahap yang dilakukan setelah menetapkan kesepakatan bersama ialah menyusun rencana kerja. Rencana kerja tersebut disusun oleh Pemerintah Daerah, Pemerintah Pusat serta masyarakat berdasarkan hasil dari kesepakatan bersama.

Beberapa langkah yang dilakukan ketika menyusun rencana kerja yaitu:

a. Membuat analisis kebutuhan, permasalahan atau isu strategis.

b. Merumuskan ide dasar atau latar belakang program.

c. Merumuskan tujuan atau target.

d. Menentukan subyek sasaran.

e. Menentukan indikator keberhasilan.

f. Merencanakan model, metode, materi.

g. Merencanakan tempat dan waktu pelaksanaan.

h. Merencanakan tim pelaksana (fasilitator).

i. Merencanakan pengelolaan dana. 
6. Mengorganisasikan, mengoordinasikan

Setelah rencana kerja tersusun, langkah yang dilakukan berikutnya adalah melakukan organisasi dan koordinasi sesuai dengan rencana kerja yang tersusun. Hal ini merupakan tindak awal sebelum proses tindakan dari rencana kerja dilaksanakan dalam kehidupan sehari-hari.

Dalam KKBI, mengorganisasi memiliki arti mengatur dan menyusun bagian (orang dan sebagainya) sehingga seluruhnya menjadi suatu kesatuan yang teratur. Sedangkan koordinasi dalam

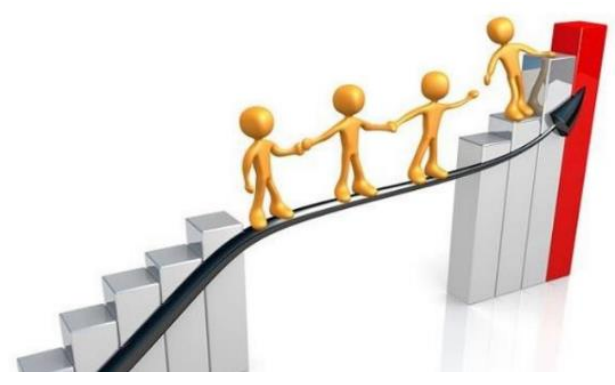
KBBI dapat diartikan sebagai perihal mengatur suatu organisasi atau kegiatan sehingga peraturan dan tindakan yang akan dilaksanakan tidak saling bertentangan atau simpang siur; penggabungan satuan gramatikal yang sederajat dengan konjungsi koordinatif.

7. Melaksanakan penguatan

Setelah melakukan organisasi dan koordinasi dari hasil rencana kerja yang telah tersusun, tahap selanjutnya adalah melaksanakan penguatan. Ini merupakan hal yang penting dari semua proses di tahap ini. Pelaksanaan penguatan dilakukan oleh semua pihak, mulai dari Pemerintah Pusat, Pemerintah Daerah serta masyarakat.

Penguatan yang dilakukan berbeda di setiap daerah dengan pertimbangan berdasarkan dari permasalahan yang terjadi serta kebudayaan dan faktor lain yang mempengaruhi pada daerah tersebut. Hal tersebut yang akan mempengaruhi pula kebijakan yang tersusun untuk penguatan di suatu tempat tersebut pula. 
8. Menyampaikan laporan

Tahapan yang terakhir dari proses ini merupakan menyampaikan laporan. Laporan ditulis guna melihat bagaimana perubahan yang terjadi dari sebelum dan sesudahnya ada penguatan yang disusun pada daerah tersebut. Tidak hanya itu, beberapa saran dan kesimpulan dari proses penguatan tersebut juga menjadi catatan penting guna perbaikan kedepannya.

Penguatan Restorasi Sosial yang dilaksanakan oleh masyarakat mengacu pada kebijakan Pemerintah Pusat dan pemerintah daerah. Penguatan Restorasi Sosial oleh masyarakat sebagaimana meliputi keluarga, badan usaha, lembaga pendidikan, organisasi masyarakat, kelompok komunitas, kelompok profesi dan media masa.

\section{B. Strategi Penguatan Restorasi Sosial}

Restorasi Sosial dilakukan melalui strategi penguatan Restorasi Sosial. Sesuai dengan Peraturan Menteri Sosial Nomor 22 Tahun 2017 mengenai Restorasi Sosial, strategi penguatan Restorasi Sosial dilakukan dengan cara:

1. Memperkuat pendidikan kebhinekaan dan menciptakan ruang dialog antarwarga

Memperkuat pendidikan kebhinekaan dan menciptakan ruang dialog antarwarga guna memupuk dan meningkatkan kesadaran masyarakat Indonesia akan kebhinekaan melalui proses ruang dialog antarwarga menuju masyarakat Indonesia yang toleransi antar sesama. Memperkuat pendidikan kebhinekaan dan menciptakan ruang dialog antarwarga dilakukan melalui beberapa hal, seperti:

a. Pendidikan karakter dan budi pekerti bangsa yang dilandasi oleh nilai-nilai kearifan lokal 
Penguatan pendidikan kebhinnekaan dapat diciptakan salah satunya melalui pendidikan karakter dan budi pekerti. Penanaman pendidikan karakter sudah mulai menjadi salah satu program dari Kementerian Pendidikan dan Kebudayaan guna bagian dari Gerakan Revolusi Mental. Di dalamnya, terdapat beberapa dimensi pengolahan karakter, yaitu olah hati (etik), olah rasa (estetis), olah piker (literasi), dan olahraga (kinestetik).

b. Peningkatan pemahaman generasi muda melalui nilainilai kesejarahan dan wawasan kebangsaan

Peningkatan nilai-nilai kesejarahan dan wawasan kebangsaan juga telah dikembangkan oleh Kementerian Pendidikan dan Kebudayaan melalui pelatihan yang diberikan kepada guru-guru khususnya guru sejarah serta membuat buku-buku bergambar mengenai cerita pahlawan guna mengenalkan pahlawan kepada generasi muda.

c. Pelindungan, pengembangan, serta aktualisasi nilai dan tradisi masyarakat untuk memperkaya dan memperkukuh khazanah budaya bangsa

Perlindungan, pengembangan, aktualisasi nilai dan tradisi masyarakat melalui pengenalan budaya-budaya pada generasi muda, salah satunya pada pelajar sekolah melalui mata pelajaran khusus mengenai bahasa dan kebudayaan daerahnya serta pengembangan ekstrakulikuler kebudayaan seperti tari tradisional di sekolah.

2. Membangun kembali modal sosial untuk memperkukuh karakter dan jati diri bangsa

Memperkokoh karakter dan jati diri bangsa Indonesia dilakukan berdasarkan asas gotong-royong dan kepedulian terhadap sosial guna membangun kembali modal sosial. 
Sikap gotong royong diharapkan masyarakat Indonesia dapat mengembalikan sikap dan karakter bangsa Indonesia yang peduli akan sesama. Membangun kembali modal sosial untuk memperkukuh karakter dan jati diri bangsa dilakukan melalui:

a. Pengembangan kepedulian sosial

Dilakukan pengembangan rasa kepedulian kepada sesama yang kini mulai memudar. Kepedulian dapat kembali dipupuk melalui menaruh perhatian kepada lingkungan disekitar. Salah satu sikap yang dapat dijadikan menjadi rasa kepedulian sosial adalah membantu ketika melihat orang tua yang sedang ingin menyebrang.

b. Pengembangan pranata gotong royong

Pengembangan pranata gotong-royong pada kehidupan sehari-hari menjadikan salah satu hal penting dari jati diri bangsa Indonesia. Rasa saling tolong-menolong dan membantu antar sesama tidak hanya menjadikan kuatnya karakter bangsa namun juga mengembalikan semangat bangsa yang sejak dahulu tertanam dalam kehidupan masyarakat. Salah satu sikap dari gotong-royong adalah melakukan kerja bakti di daerah lingkungan bersama tetangga.

c. Penggalang inisiatif komunitas untuk merencanakan dan ikut menyediakan kebutuhan komunitas mereka sendiri

Membangun dan mengembangkan komunitas yang bermanfaat untuk sesama. Salah satunya dapat melalui membentuk komunitas untuk membantu mengajar sebagai guru kepada orang-orang yang tidak mampu bersekolah. 
d. Pemberdayaan masyarakat adat dan komunitas budaya

Pemberdayaan masyarakat adat dan komunitas budaya menjadi salah satu cara untuk tetap melestarikan kebudayaan di Indonesia. Pengembangan pemberdayaan masyarakat adat tidak hanya menjadi bagian dari bentuk kepedulian terhadap kebudayaan, tetapi juga dapat dikolaborasikan bersama nilai-nilai ekonomi di dalamnya sehingga tidak hanya melestarikan namun juga dapat menjadi nilai ekonomi bagi masyarakatnya. Salah satunya seperti pengembangan Desa Sade di Nusa Tenggara Barat. Desa Sade merupakan desa adat yang dijadikan sebagai tempat pariwisata. Melalui mempertahankan kebudayaan yang ada seperti bentuk rumah adat, tradisi seperti taritarian hingga menenun dengan cara tradisional.

e. Pengembangan karakter dan jati diri bangsa

Pada buku Pembinaan Pendidikan Karakter di Sekolah Menengah Pertama disebutkan bahwa pengembangan karakter dalam suatu sistem pendidikan adalah keterkaitan antara komponen-komponen karakter yang mengandung nilai-nilai perilaku, yang dapat dilakukan atau bertindak secara bertahap dan saling berhubungan antara pengetahuan nilai-nilai perilaku dengan sikap atau emosi yang kuat untuk melaksanakannya, baik terhadap Tuhan YME, dirinya, sesama, lingkungan, bangsa dan negara serta dunia internasional.

Pengembangan karakter seharusnya membawa anak ke pengenalan nilai secara kognitif, penghayatan nilai secara afektif, akhirnya ke pengamalan nilai secara nyata. Untuk sampai ke praksis, ada satu peristiwa batin yang amat penting yang harus terjadi dalam diri anak, yaitu munculnya keinginan yang sangat kuat (tekad) untuk mengamalkan nilai. 
Sedangkan, Mustakim (2018) menjelaskan jati diri atau yang lazim juga disebut identitas merupakan ciri khas yang menandai seseorang, sekelompok orang, atau suatu bangsa. Jika ciri khas itu menjadi milik bersama suatu bangsa, hal itu tentu menjadi penanda jati diri bangsa tersebut. Dengan jati diri yang kuat, bangsa kita akan makin bermartabat sehingga mampu berperan bahkan juga bersaing dalam kancah kehidupan global.

3. Meningkatkan peran kelembagaan sosial

Lembaga sosial adalah suatu sistem norma yang bertujuan untuk mengatur tindakan-tindakan maupun kegiatan masyarakat dalam rangka memenuhi kebutuhan pokok dan bermasyarakat bagi manusia.

Kelembagaan sosial mengatur semua anggota masyarakat dalam segala aspek kehidupannya mulai dalam lingkungan terkecil (keluarga) sampai kepada kehidupan politik. Karena di dalam lembaga atau pranata sosial itu terdapat berbagai kumpulan norma atau sistem norma yang harus ditaati oleh setiap orang dalam hubungan yang dilakukannya dengan orang lain atau sekelompok orang. Meningkatkan peran kelembagaan sosial dilakukan dapat dilakukan melalui:

a. pengembangan sistem rujukan dan layanan terpadu di tingkat daerah kabupaten/kota

b. pengembangan kompetensi dan kertersediaan tenaga kesejahteraan sosial

c. peningkatan kualitas dan standardisasi lembaga kesejahteraan sosial sebagai agen kesetiakawanan social

4. Meningkatkan partisipasi pemuda dalam pembangunan

a. Keberadaan pemuda sangat penting dalam sebagai sumber pembangunan bangsa. Pemuda Indonesia dan di seluruh dunia merupakan sumber daya utama untuk 
pembangunan. Mereka dapat berperan dalam menjadi agen kunci perubahan sosial, pertumbuhan ekonomi dan inovasi teknologi. Guna meningkatkan partisipasi pemuda dalam pembangunan dilakukan melalui:

b. perluasan memperoleh pendidikan dan keterampilan

c. peningkatan peran serta pemuda dalam pembangunan sosial, politik, ekonomi, budaya, dan agama

d. peningkatan potensi pemuda dalam kewirausahaan

e. kepeloporan, dan kepemimpinan dalam pembangunan

f. pelindungan generasi muda terhadap bahaya penyalahgunaan narkotika, psikotropika, dan zat adiktif lainnya, minuman keras, penyebaran penyakit Human Immunodeficiency Virus dan Acquired Immune Deficiency Syndrome, serta penyakit menular seksual di kalangan pemuda

5. Meningkatkan pembudayaan kesetiakawananan sosial dalam penyelenggaraan kesejahteraan sosial

Berdasarkan Peraturan Menteri Sosial Nomor 10 Tahun 2015, kesetiakawanan sosial merupakan nilai dasar bangsa Indonesia yang perlu ditanamkan, dilestarikan dan dikuatkan. Kesetiakawanan sosial adalah nilai dasar yang terwujud dalam bentuk pikiran, sikap dan tindakan saling peduli dan berbagi yang dilandasi oleh kerelaan, kesetiaan, kebersamaan, toleransi dan kesetaraan guna meningkatkan harkat, martabat dan harga diri setiap warga negara Indonesia. Penguatan kesetiakawanan sosial adalah upaya memperkuat penanaman dan pelestarian kesetiakawanan sosial secara terarah, terpadu, terencana dan berkelanjutan. Meningkatkan pembudayaan kesetiakawanan sosial dalam penyelenggaraan kesejahteraan sosial dilakukan melalui: 
a. peningkatan penyuluhan sosial

b. penguatan peran Pemerintah Pusat, pemerintan daerah, dan masyarakat dalam penyelenggaraan kesetiakawanan sosial

c. peningkatan jejaring kerja kesetiakawanan sosial

\section{Pelaksanaan Penguatan Restorasi Sosial}

Penguatan Restorasi Sosial dilakukan dengan cara:

1. Kampanye Restorasi Sosial

Kampanye Restorasi Sosial merupakan perwujudan persemaian budaya untuk penguatan Restorasi Sosial yang dilakukan secara terencana, terarah, terpadu, berkelanjutan, dan terkoordinasi.

Kampanye Restorasi Sosial berupa:
a. sosialisasi
b. diseminasi
c. penataran
d. lokakarya
e. seminar
f. forum diskusi

2. Jejaring Kerja Restorasi Sosial

Jejaring kerja Restorasi Sosial merupakan upaya membangun ikatan kerja dan kemitraan antar kelompok serta berbagai lembaga yang dapat memberikan kontribusi dalam mendukung kegiatan Restorasi Sosial.

Jejaring kerja Restorasi Sosial dilakukan dengan cara:

a. menciptakan ruang dialog antara pemangku kepentingan 
b. mengedepankan adanya kesamaan sudut pandang, tujuan, dan rasa

c. membuat komitmen untuk bekerja bersama dan saling bantu dalam suasana yang toleran

3. Bengkel Karakter

Bengkel karakter merupakan kegiatan penyampaian informasi mengenai materi Restorasi Sosial, pembinaan, dan pembentukan karakter berjiwa sosial bagi generasi muda yang dilakukan secara terstruktur dan berkelanjutan.

Bengkel karakter dilakukan melalui:
a. bimbingan teknis
b. pendidikan karakter
c. penyuluhan.

4. Aksi Sosial

Aksi sosial merupakan tindakan sosial yang dilakukan secara terencana, terarah, terpadu, berkelanjutan, dan terkoordinasi untuk merestorasi kehidupan sosial masyarakat.

Aksi sosial dilaksanakan dengan cara:

a. memperingati hari besar nasional

b. gerakan masyarakat peduli dan berbagi

c. bakti sosial 
78 | RESTORASI SOSIAL 


\section{BAB V RESTORASI SOSIAL DI JEPANG DAN KOREA SELATAN}




\section{A. Restorasi Sosial di Jepang}

Restorasi Sosial di Jepang dikenal dengan Restorasi Meiji. Hal ini kemudian merupakan Rahasia Kesuksesan Bangsa Jepang.

Restorasi Meiji, Meiji Ishin, Revolusi Meiji, atau Pembaruan Meiji

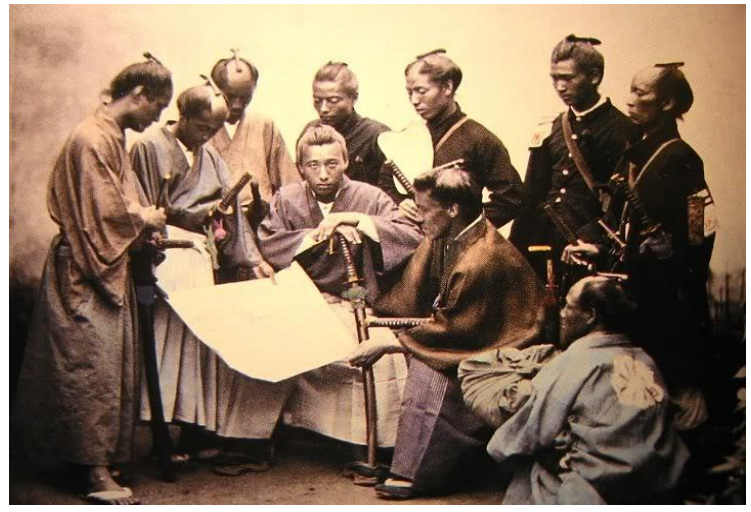

kekuasaan di Jepang kepada Kaisar pada tahun 1868, sebagai awal zaman Meiji.

Restorasi ini membawa perubahan besar-besaran struktur politik dan sosial Jepang, dan berlanjut hingga zaman edo. Kata Meiji sendiri berarti kekuasaan pencerahandan pemerintah waktu itu bertujuan menggabungkan "kemajuan Barat" dengan nilai-nilai "Timur" tradisional.

Dalam sejarah Jepang, babak pertama pemerintahan diktator militer feodalisme korup dimulai dengan kudeta Tokugawa Ieyasu atas kekuasaan kaisar sebagai pemerintahan yang sah setelah melewati pertempuran Sekihara tahun 1600. Karena terhalang garis keturunan untuk menjadi jenderal, Tokugawa Ieyasu memalsukan silsilah keturunan menjadi klan Minamoto agar bisa 'absah' menjadi Shogun. Sebab, Shogun, yang dalam konteks sejarah Jepang adalah Sei-i Taishogun, Jenderal Panglima Tertinggi Angkatan Bersenjata, hanya berhak dijabat oleh keturunan klan Minamoto. 
Inilah babak pertama pemerintahan diktator militer feodalisme di Jepang. KeshogunanTokugawa berkuasa turuntemurun 15 generasi selama 265 tahun sejak 24 Maret 1603 dengan pengangkatan Tokugawa Ieyasu sebagai Sei-i Taishōgun dan berakhir pada 9 November 1867 ketika Tokugawa Yoshinobu (Keiki), Shogun

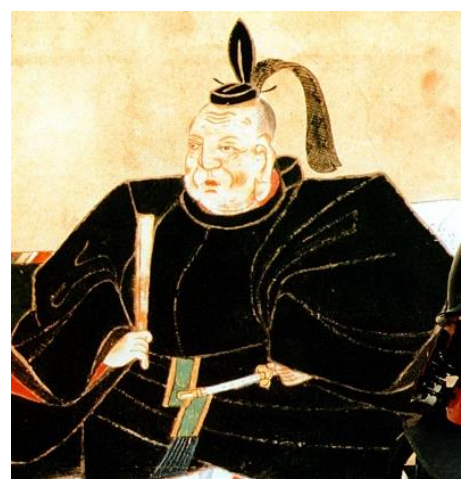
generasi terakhir mengembalikan kekuasaan ke tangan kaisar (Taisei Hōkan).

Inilah era zaman edan ala Jepang, disebut Zaman Edo, merujuk pada ibukota Edo (sekarang Tokyo), zaman kegelapan KeshogunanTokugawa atau Keshogunan Edo (Edo Bakufu). Di masa ini, kekuasaan kaisar yang berkedudukan di Kyoto hanyalah simbolik belaka tanpa daya, sebab istana kaisar hanya mengeluarkan kebijakan, sedang yang menjalankan wewenangnya adalah klan Shogun Tokugawa.

Di masa ini, oleh Toyotomi Hideyoshi rakyat Jepang dibagi-bagi menurut sistem kelas. Kelas samurai berada di hirarki paling atas, diikuti petani, pengrajin dan pedagang. tak ayal, pemberontakan sering terjadi akibat kekuasaan yang korup, kakunya pembagian sistem kelas dan tidak memungkinkan orang untuk berpindah kelas. Pajak semena-mena yang dikenakan terhadap petani selalu berjumlah tetap tanpa memperhitungkan inflasi.

Samurai yang menguasai tanah harus menanggung akibatnya, karena jumlah pajak yang berhasil dikumpulkan semakin hari nilainya semakin berkurang. Perselisihan soal pajak sering menyulut pertikaian antara petani kaya dan kalangan samurai yang terhormat tapi kurang makmur. Pertikaian sering memicu kerusuhan lokal hingga pemberontakan berskala besar yang umumnya dapat segera dipadamkan. 
Seiring waktu berjalan, kelompok anti keshogunan Tokugawa justru semakin bertambah kuat. Era Bakumatsu datang, era Edo mulai terancam keruntuhan. Dimulai dengan kedatangan Kapal Hitam Angkatan Laut Amerika Serikat di bawah pimpinan komodor Matthew C. Perry tahun 1853, Jepang yang selama ini terkungkung dalam isolasi mulai membuka mata melihat kemajuan dunia Barat. Keshogunan yang akhirnya bekerjasama dengan asing dalam Perjanjian Shimoda dan Perjanjian Towsen Harris menggugah kesadaran bangsa Jepang untuk bangkit dari keterpurukan dan kungkungan tiran penguasa korup Tokugawa.

Gelombang pembaharuan menggelora. Spirit perlawanan terhadap penguasa korup dan sentimen anti barat menjadi dua kekuatan yang mengobarkan perlawanan terhadap feodalisme keshogunan. Sakamoto Ryoma mencetuskan pembentukanaliansi nasionalis pro-kekaisaran Satsuma-Choshu antara Saigo Takamori (pemimpin Domain Satsuma) dan Kido Tkayoshi (pemimpin Domain Choshu) untuk melawankeshogunan yang didukung samurai elit Shinsengumi.

Dengan slogan politik "Sonnō jōi!" (Dukung kaisar, usir barbar!), perjuangan aliansi pro-kaisar membuahkan hasil. Pada 9 November 1867 Tokugawa Yoshinibu menyerahkan kekuasaan ke tangan kaisar (Taisei Hōkan), kaisar Komei. Pada 3 Februari 1867, Kaisar Meiji naik tahta menggantikan ayahnya, Kaisar Kōmei yang wafat pada 30 Januari 1867. Peristiwa ini merupakan titik awal "restorasi" kaisar Meiji, meskipun Yoshinobu masih tetap memiliki kekuasaan yang signifikan.

Pada Januari 1868, pecah perang Boshin (Perang Tahun Naga) dan Pertempuran Toba-Fushimi. Dalam pertempuran itu, tentara aliansi Satsuma-Choshu mengalahkan tentara mantan keshogunan. Kaisar Meiji mencopot semua kekuasaan yang dimiliki Yoshinobu, dan "restorasi" secara resmi dapat dimulai. Pada 3 Januari 1869, Kaisar mengeluarkan deklarasi formal tentang pengembalian kekuasaan ke tangannya. 


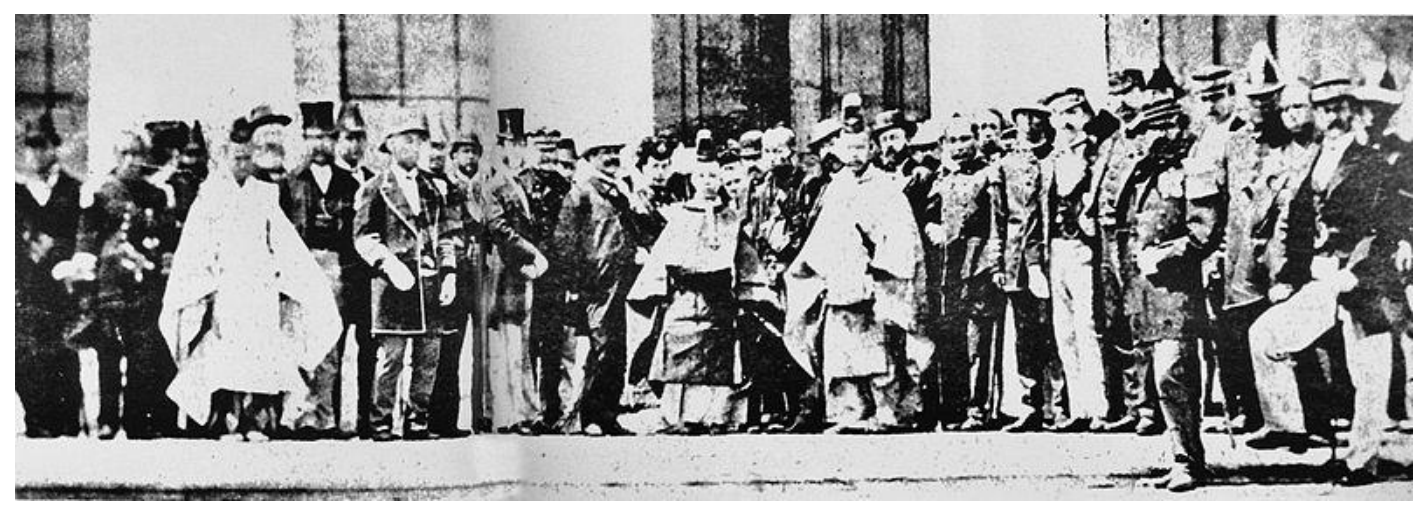

Kaisar Jepang mengumumkan kepada semua kepala negara dari negara-negara asing beserta 'antek-antek' mereka bahwa izin telah diberikan kepada Shogun Tokugawa Yoshinobu untuk mengembalikan kekuasaan pemerintah sesuai dengan permintaannya sendiri.

"Mulai saat ini kami akan melaksanakan kekuasaan tertinggi untuk urusan-urusan dalam dan luar negeri dari negara ini. Maka dari itu, semua penyebutan Taikun dalam perjanjian-perjanjian yang telah dibuat harus diganti dengan perkataan Kaisar.Para pejabat sedang ditunjuk oleh kami untuk melaksanakan urusan-urusan luar negeri. perwakilan-perwakilan dari negara-negara penandatangan traktat hendaknya memaklumi pengumuman ini."

Sejumlah petinggi keshogunan mengajak tentaranya melarikan diri ke Hokkaido, dan mencoba mendirikan negara merdeka bernama Republik Ezo. Namun tentara yang setia kepada kekaisaran mengakhiri upaya mereka dalam Pertempuran Hakodate di Hokkaido, Mei 1869. Kekalahan tentara mantan keshogunan yang dipimpin olehEnomoto Takeaki dan Hijikata Toshizo menandai tamatnya Keshogunan Tokugawa dan pemulihan sepenuhnya kekuasaan di tangan Kaisar.

Pemerintah Oligarki Meiji yang bertindak atas nama kekuasaan kaisar memperkenalkan upaya-upaya konsolidasi kekuasaan untuk menghadapi sisa-sisa pemerintahan zaman Edo, keshogunan, daimyo dan samurai. Pada tahun 1868, semua tanah feodal milik Keshogunan Tokugawa disita dan dialihkan di bawah "kendali 
kekaisaran". Tindakan ini sekaligus menempatkan mereka di bawah kekuasaan pemerintahan baru Meiji. Pada tahun 1869, daimyo Domain Tosa, Domain Hizen, Domain Satsuma dan Domain Choshu yang telah berjasa melawan kekuasaankeshogunan, dibujuk untuk mau "mengembalikan domain mereka kepada kaisar."

Daimyo lainnya juga selanjutnya diperintahkan untuk melakukan hal yang sama. Dengan adanya penghapusan wilayah domain, maka untuk pertama kalinya tercipta pemerintahan Jepang yang terpusat dan berkuasa di semua wilayah negeri.

Pada tahun 1871, semua daimyo dan mantan daimyo dipanggil untuk menghadap kaisar untuk menerima perintah pengembalian semua domain kepada kaisar. Sekitar 300 domain (han) diubah bentuknya menjadi prefektur yang dipimpin oleh gubernur yang ditunjuk oleh negara.

Pada tahun 1888, beberapa prefektur telah berhasil dilebur menjadi satu sehingga jumlah prefektur menciut menjadi 75 prefektur. Kepada mantan daimyo, pemerintah berjanji untuk menggaji mereka sebesar 1/10 dari pendapatan bekas wilayah mereka sebagai penghasilan pribadi. Selanjutnya, utang-utang mereka berikut pembayaran gaji serta tunjangan untuk samurai diambil alih oleh negara.

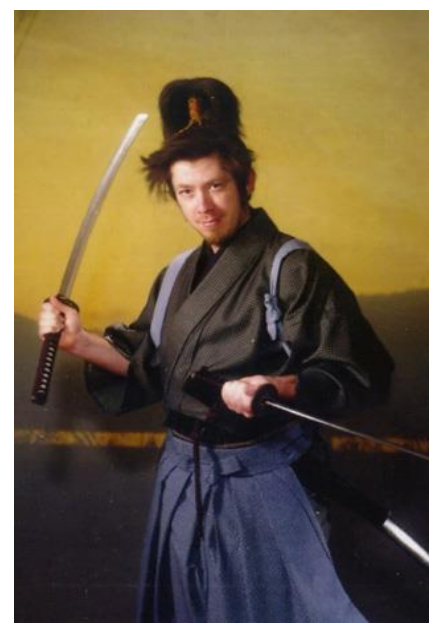

Semasa Restorasi Meiji, feodalisme Jepang secara perlahan-lahan digantikan oleh ekonomi pasar dan menjadikan Jepang sebagai negara yang dipengaruhi negaranegara Barat hingga kini. Restorasi Meiji menekankan pendidikan sebagai mata tombak reformasi dan modernisasi. Pendidikan menjadi hak dan kewajiban semua warga. Inilah salah satu kunci keberhasilan restorasi Jepang, yang 
menjadikan negara ini cepat beradaptasi dengan perkembangan sains dan teknologi Barat di masa selanjutnya, disamping administrasi pemerintahan yang sangat rapi warisan dari rezim Tokugawa.

Faktor yang tak kalah pentingnya dalam membawa keberhasilan restorasi adalah karakteristik kepribadian bangsa Jepang yang sangat dipengaruhi oleh spirit Bushido dan filosofi samurai yang sangat asketik, pekerja keras, berdisiplin tinggi, pantang menyerah, totalitas loyalitas dan menjunjung tinggi tradisi, kode etik dan tata krama dalam kehidupan.

Menjelang akhir abad ke 19 Jepang sudah berhasil menjadi kekuatan militer dengan angkatan laut yang sangat tangguh sehingga dapat mengalahkan secara mutlak armada raksasa Rusia di Selat Tsushima, menyapu bersih kepulauan Sachalin, mengambil Korea dan Semenanjung Liau-Tung dari Rusia, serta Port Arthur dan Dairen (Wells, 1951).

Dalam kurun waktu kurang dari 4 dekade, Restorasi Meiji sukses mengakselerasi industrialisasi di Jepang yang dijadikan modal untuk kebangkitan Jepang sebagai kekuatan militer pada tahun 1905 di bawah slogan "Negara Makmur, Militer Kuat" (fukoke kyohei).

Pengaruh mendasar lainnya pada keberhasilan restorasi Meiji adalah kehadiran bangsa Amerika di Jepang dengan perubahan Konstitusi Jepang yang dibuat atas supervisi Jenderal MacAthur, dan konstitusi itu masih berlaku hingga kini. Di bawah asuhan Jenderal MacArhur, Jepang tumbuh kembali menjadi negara ekonomi yang sangat tangguh, sehingga menjadi super power dalam bidang ekonomi hingga kini.

Restorasi Meiji, dengan semangat bushido samurai khas ksatria Jepang, negara ini mampu merevolusi feodalisme korup yang telah berlangsung 265 tahun dan kini menjadi negara maju dalam industri dan perkasa dalam ekonomi di arena dunia. Jika dihitung 
dari awal tercetusnya tahun 1853 berarti kini tela memasuki tahun ke-152. Satu setengah abad dalam sejarah perjuangan bangsa Jepang untuk bisa berjaya.

Bagaimana dengan Indonesia? Dua sejarah dan latar belakang bangsa yang sebenarnya tak jauh berbeda. Sudahkah negeri ini mulai merombak struktur politik, sosial dan budaya secara menyeluruh dengan semangat juang prawira-ksatria-mujahidkhas Indonesia seperti halnya semangat bushido dan filosofi samurai khas Jepang. Entah dengan nama revolusi, reformasi, rekonstruksi atau restorasi, tujuannya adalah perubahan, pembarauan, perbaikan total. Jika belum, sepertinya semua harus bersabar menunggu sampai tahun 2160-an, 150 tahun lagi untuk mengikuti jejak Jepang, itupun jika langkah itu mulai diayunkan hari ini.

\section{B. Restorasi Sosial di Korea Selatan}

\section{Saemaul Undong}

Restorasi Sosial di Korea dikenal dengan Saemaul-Undong yang merupakan Penggerak Perubahan Perekonomian Korea Selatan.

Berdasarkan tulisan yang ditulis oleh Yumi Angela berjudul Saemaul Undong: Modal Sosial Sebagai Energi Super Power dalam Pembangunan Di Korea menjelaskan bagaimana Saemaul Undong menjadi sebuah gerakan nasional yang merubah Korea Selatan dari percepatan baik pembangunan infrastruktur, naiknya pendapat, semakin baiknya kondisi lingkungan tempat tinggal dan komunitas serta aspek lainnya.

Saemaul Undong merupakan gerakan pembangunan masyarakat desa yang membawa pencerahan spiritual dan kondisi kehidupan yang lebih baik (pendapatan, infrastruktur, lingkungan tempat tinggal dan komunitas) (Angelia, 2015). Gerakan ini didasarkan pada semangat 
menolong diri sendiri dan kerja sama dengan dukungan dari Pemerintah.

\section{Tujuan Saemaul Undong}

Saemaul Undong memiliki tujuan jangka menengah dan jangka panjang. Tujuan jangka menengahnya adalah mencapai kondisi kehidupan yang baik, sedangkan tujuan jangka panjangnya ialah membangun komunitas masyarakat yang baik dan modern, sehingga akhirnya dapat membangun bangsa yang kuat (Angelia, 2015). Tujuan jangka panjang tersebut dilakukan melalui beberapa hal seperti:

a. Peningkatan Pendapatan Rumah Tangga Petani

Pendapatan rumah tangga petani terdiri dari pendapatan dari hasil ladang dan pendapatan lainnya. Menemukan varietas unggulan yang dapat meningkatkan produktivitas, irigasi, teknologi penanaman dan pengelolaan lahan yang lebih maju, pemanenan, prosesing dan pemasaran merupakan aspek yang diperlukan untuk meningkatkan pendapatan petani. Menciptakan lapangan kerja baru dengan pembangunan pabrik pengolahan makanan, pasar, dan pelayanan masyarakat desa merupakan aspek lainnya yang mendapatkan perhatian untuk meningkatkan pendapatan petani (Angelia, 2015).

b. Pembangunan Infrastruktur Desa

Peningkatan infrasruktur desa diperlukan untuk meningkatkan produktivitas pertanian dan menambah kenyamanan kehidupan di desa. Infrastruktur desa dapat digolongkan menjadi dua yaitu infrastruktur produksi pertanian dan sosial pedesaan (Angelia, 2015).

c. Peningkatan lingkungan tempat tinggal

Pembangunan tempat MCK, dapur, sistem pembuangan limbah rumah tangga untuk menciptakan kondisi kerja dan tempat tinggal yang memenuhi standar sanitasi (Angelia, 2015). Penanaman pohon dan tanaman bunga 
untuk menciptkan lingkungan yang asri, membuat taman dan fasilitas publik untuk tempat berkumpul masyarakat desa. Aliran sungai dan hutan dilestarikan untuk menjaga keseimbangan ekosistem.

d. Menghidupkan spiritualitas penduduk desa Mengembangkan kesadaran pembangunan dan menularkan semangat kerajinan, kerja sama dan menolong diri sendiri (Angelia, 2015). Walaupun penduduk desa menyadari kebutuhan untuk membangun, mereka tidak memiliki akses dalam pembangunan. Oleh karena itu pemerintah menyediakan pelatihan dan penyuluhan untuk membangkitkan jiwa kepemimpinhan, dan mempelajari cara pengelola sumberdaya dan menghasilkan produk bernilai sebagai aktivitas ekonomi. Masyarakat desa perlu mengembangkan organisasi masyarakat yang lebih efisien untuk peningkatan kinerja mereka.

\section{Perkembangan Saemaul Undong}

Pelaksanaan Saemaul Undong diawali dengan pemberian semen untuk pembangunan infrastruktur desa. Kemudian berkembang ke arah menstimulasi kebutuhan pembangunan, penyelesaian permasalahan desa (Angelia, 2015). Selanjutnya pelatihan pemimpin Saemaul Undong desa, perkembangan Saemaul Undong ke daerah perkotaan dalam pembangunan pabrik dilandasi kerja sama dan self help kemudian berkembang lebih luas menjadi kampanye nasional.

Pada 10 tahun pertama pelaksanaan Saemaul Undong, sudah terkumpul investasi sebesar 5.258 milyar won dengan sharing dari pemerintah 51\% dan masyarakat 49\% (Angelia, 2015). Infrastruktur yang dibangun adalah jalan produksi sepanjang $6.187 \mathrm{~km}, 82.596$ jembatan, 39.231 tempat pertemuan masyarakat, dan 258.000 unit rumah. 


\section{Strategi Saemaul Undong}

Menurut Angelia (2015) terdapat tiga pendekatan mendasar dalam Saemaul Undong yaitu:

a. Pendekatan Top Down-Community Based

Filosofi pembangunan masyarakat (community development) adalah masyarakat harus menidentifikasi sendiri masalahnya dan sekaligus menemukan sendiri solusi yang terbaik bagi mereka (Angelia, 2015). Masyarakat tidak akan berpartisipasi pada program pembangunan apabila kegiatan tersebut tidak menjadi kebutuhan mereka.

Tetapi seringkali masyarakat tidak dapat mengidentifikasi kebutuhannya karena mereka tidak menyadari apa yang mereka butuhkan atau sekalipun mereka menyadari kebutuhan pembangunan, mereka tidak termotivasi untuk membangun karena mereka tidak memiliki sumberdaya dan pengetahuan untuk mencapai kebutuhannya. Oleh karenanya mereka membutuhkan bantuan pihak eksternal untuk mencapai kebutuhannya.

Saemaul Undong menggunakan pendekatan Top DownCommunity Based untuk memotivasi masyarakat dan membawa kebutuhan pembangunan yang dibutuhkan masyarakat (Angelia, 2015). Pemerintah menyediakan kebutuhan pembangunan dan pelatihan bagi masyarakat desa untuk menyadarkan mereka tentang kebutuhan pembangunan dan untuk mengelola kelompok masyarakat untuk melaksanakan kegiatan/proyek pembangunan.

Pendekatan ini merupakan strategi yang unik, bertujuan untuk meletakkan dasar pembangunan dan memberikan pencerahan bagi masyarakat desa tentang pentingnya pendekatan bottom up. Dengan subsidi, dukungan 
administrasi yang intensif, pembinaan dari Pemerintah, masyarakat desa ditantang untuk memilih pemimpin mereka, memilih kegiatan dan melakukan perencanaan program dan pelaksanaan untuk meningkatkan standar kehidupan mereka.

Pada proses ini Pemerintah tetap menjamin kemandirian penduduk desa untuk memutuskan penggunaan subsidi dan cara mereka membangun sesuai dengan kebutuhannya. Subsidi dan inisiatif pemerintah akan berkurang secara bertahap jika masyarakat desa telah mencapai tingkat pembangunan tertentu.

b. Pendekatan Terpadu

Pembangunan masyarakat harus dipadukan secara vertikal dan horisontal pada tingkat masyarakat (Angelia, 2015). Integrasi vertikal berarti koordinasi antara pembangunan tingkat masyarakat dan kebijakan pembangunan Pemerintah Pusat. Integrasi horisontal berarti integrasi di antara sektor pada tingkat masyarakat.

Integrasi horizontal berarti kegiatan pembangunan individu di tingkat desa harus terintegrasi dengan perencanaan pembangunan desa (Angelia, 2015). Di desa seringkali terjad berbagai perencanaan pembangunan dilakukan oleh berbagai kementerian, badan, LSM pada kelompok tani yang sama. Sumber penganggaran yang berbeda dan perbedaan kepentingan menyebabkan kegiatan pembangunan di tingkat desa sulit dipadukan. Untuk dampak pembangunan yang lebih nyata, kegiatan/program pembangunan tersebut harus diintegrasikan dalam perencanaan pembangunan masyarakat yang komprehensif. 
Integrasi vertikal. Setiap masyarakat desa mengembangkan rencana aksi Saemaul Undong masingmasing dengan dukungan subsidi dan pelatihan dari pemerintah. Setiap tahun pemerintah pusat menyediakan bahan pembangunan seperti semen, besi dan subsidi anggaran untuk partisipasi masyarakat desa dalam program Saemaul Undong. Oleh karena itu rencana pembangunan tingkat mikro harus terintegrasi dengan kebijakan Pemerintah Pusat terkait pembangunan desa (Angelia, 2015).

Saemaul Undong merupakan gerakan penyadaran masyarakat desa untuk hidup lebih baik, sehingga tidak dapat diselesaikan sekaligus, tetapi melalui pelaksanaan kegiatan berkelanjutan selama beberapa tahun, dan tahap demi tahap. Rencana Aksi Saemaul Undong biasanya ditetapkan untuk tujuan pembangunan 5 tahun, sehingga masyarakat desa memiliki visi capaian target pembangunan dalam 5 tahun dan berupaya mencapai target tersebut.

Berdasarkan Angelia (2015), kebijakan Saemaul Undong dalam skala mikro antara lain: (1) Peningkatan pendapatan (pertanian dan non pertanian); Pembangunan infrastruktur (Infrastruktur pertanian dan sosial); (3) Pembangunan komunitas (Pembangunan gedung-gedung pertemuan dan pembangunan lingkungan pedesaan); (4) Pengembangan sosial budaya (penguatan kelembagaan masyarakat); dan (5) Kesehatan dan Sanitasi (pengadaan air bersih, MCK dan lainnya).

c. Pendekatan The Better the More

Untuk pelaksanaan Saemaul Undong yang lebih baik, peran pemerintah daerah dan pemimpin Saemaul Undong perlu ditingkatkan (Angelia, 2015). Oleh karena itu 
Pemerintah Pusat mendirikan Saemaul Traning Institute untuk melatih pemimpin lokal dan pemimpin Saemaul tentang spirit Saemaul, membangun kepemimpinan, administrasi publik, organisasi masyarakat dan teknologi professional dalam pertanian, kehutanan, perinakan dan lainnya.

Setelah pelatihan, pemimpin Saemaul harus dikenal kewenangan dan profesinya, sehingga pemerintah mengeluarkan kartu identitas. Pemimpin Saemaul diberikan kesempatan untuk memainkan peran penting dalam pertemuan masyarakat (Angelia, 2015). Untuk meningkatkan motivasi dan prestasi pemimpin Saemaul, Pemerintah memberikan penghargaan Saemaul.

Untuk membangun konsensus nasional, pelatihan Saemaul melibatkan bukan saja pemimpin Saemaul tetapi pemimpin politik, pegawai pemerintah, tokoh masyarakat dan pemimpin lokal. Peserta pelatihan terdiri dari berbagai organisasi mayarakat dan pemerintah sehingga dapat saling memahami. 


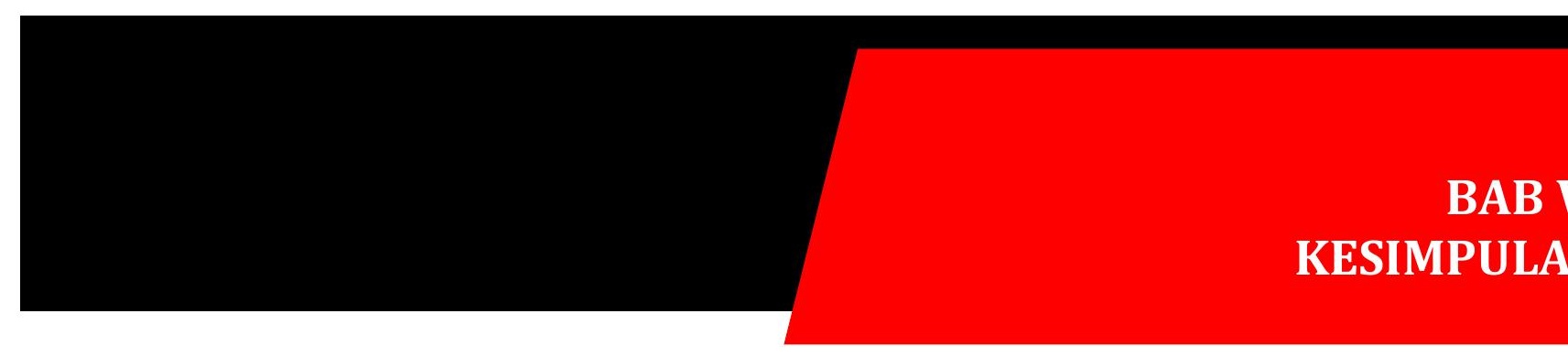


Perkembangan teknologi yang semakin maju menjadikan mudahnya untuk mengakses data dan informasi serta berkomunikasi semakin cepat dan mudah. Kemajuan teknologi tanpa diimbangi literasi yang cukup membuat masyarakat Indonesia menghadapi sebuah tantangan baru, dimana mulai terlihat memudarnya semangat persatuan dan plurarisme yang selama ini menjadi bagian penting dari bangsa ini. Diperlukan penguatan kembali rasa solidaritas guna memperteguh kebhinnekaan serta membangun kembali restorasi sosial Indonesia.

Restorasi Sosial dilakukan dengan memberikan penguatan pada masyarakat guna menumbuhkan kembali nilai-nilai luhur budaya bangsa Indonesia. Berdasarkan Peraturan Menteri Sosial Nomor 22 Tahun 2017 mengenai Restorasi Sosial, penguatan restorasi sosial dilakukan oleh Pemerintah Pusat, pemerintah daerah, dan masyarakat. Penguatan Restorasi Sosial dilaksanakan secara terencana, terarah, terpadu, berkelanjutan, dan terkoordinasi.

Strategi yang digunakan untuk penguatan restorasi sosial melalui penguatan dibeberapa unsur yaitu memperkuat pendidikan kebhinekaan dan menciptakan ruang dialog antarwarga, membangun kembali modal sosial untuk memperkukuh karakter dan jati diri bangsa, membangun kembali modal sosial untuk memperkukuh karakter dan jati diri bangsa, meningkatkan peran kelembagaan sosial, meningkatkan partisipasi pemuda dalam pembangunan, meningkatkan pembudayaan kesetiakawanan sosial dalam penyelenggaraan kesejahteraan sosial.

Dalam pelaksanaannya, penguatan restorasi sosial dilakukan melalui empat cara yaitu kampanye restorasi sosial, jejaring kerja restorasi sosial, bengkel karakter, dan aksi sosial. Melalui empat hal tersebut, diharapkan restorasi sosial dapat semakin kuat. 


\section{DAFTAR PUSTAKA}

Angelia, Y. 2015. Saemaul Undong: Modal Sosial Sebagai Energi Super Power

dalam Pembangunan di Korea.

Bentuk Solidaritas Kebersamaan Anak-Anak Sekolah. Diakses pada 22

November 2018 pada https://goo.gl/images /wXHA5B

Coser, L. 1956. The Functions of Social Conflict. Inggris: Routledge

Farisi, A. (2016). Konsep Sosial Dalam Islam Dari Sudut Pandang Surat Ali-

Imran Ayat 133-134. Diakses pada 22 November 2018 pada http://farisiahmad.com/2016/08/12/ konsep-sosial-dalamislam-dari-sudut-pandang-surat-ali-imran-ayat-133-134/

Farisi, A. 2014. Konsep Sosial dalam Islam.

Gilir Balik. Diakses pada 22 November 2018 pada https://www.idntimes.com/life/inspiration/shandypradana /5-kearifan-lokal-ini-bantu-kurangi-efek-globalwarming-c1c2/full

Hardiman, F. 1990. Kritik Ideologi. Jakarta: Kanisius

Haryanto, S. 2016. Spekturm Teori Sosial. Jogjakarta: AR-Russ Media.

Ilmu Pamali. Diakses pada 22 November 2018 pada https://www.idntimes.com/life/inspiration/shandypradana /5-kearifan-lokal-ini-bantu-kurangi-efek-globalwarming-c1c2/full

Ilmu Pikukuh. Diakses pada 22 November 2018 pada 
https://www.idntimes.com/life/inspiration/shandypradana /5-kearifan-lokal-ini-bantu-kurangi-efek-globalwarming-c1c2/full

Ilmu Tiga Hutan. Diakses pada 22 November 2018 pada https://www.idntimes.com/life/inspiration/shandypradana /5-kearifan-lokal-ini-bantu-kurangi-efek-globalwarming-c1c2/full

Johnson, D. 1994. Teori Sosiologi Klasik dan Modern. Jakarta:

Gramedia

Pustaka Utama

Kebersamaan diantara Perbedaan. Diakses pada 22 November 2018 pada

https://goo.gl/images/63NdGz

Kementerian Pendidikan Nasional. Direktorat Jenderal Manajemen Pendidikan

Dasar dan Menengah. Direktorat Pembinaan Sekolah

Menengah Pertama. 2010. Pembinaan Pendidikan Karakter di Sekolah Menengah Pertama. Jakarta

Kerusuhan Antar Warga. Diakses pada 22 November 2018 pada https://goo.gl/images/7FCdDE

Kesepakatan Bersama. Diakses pada 22 November 2018 pada https://www.jejamo.com/mustafa-rangkul-tokohmasyarakat-dan-adat-deklarasikan-kesepakatanpengamanan-lampung-tengah.html

Koordinasi. Diakses pada 22 November 2018 pada https://goo.gl/images/BkGgrr

Kuntowijoyo. 1997. Identitas Politik Umat Islam. Jakarta: Mizan 
Kuntowijoyo. 2001. Muslim Tanpa Masjid: Esai-Esai Agama, Budaya, dan

Politik dalam Bingkai Strukturalisme Transendental. Jakarta: Mizan

Maliki, Z. (2003). Narasi Agung: Tiga Teori Sosial Hegemonik. Surabaya:

Lembaga Pengkajian Agama dan Masyarakat (LPAM).

Mustakim (2018). Bahasa sebagai Jati Diri Bangsa. Badan Pengembangan dan

Pembinaan Bahasa. Kementerian Pendidikan dan Kebudayaan.

Muttaqin, H. 2015. Menuju Sosiologi Profetik.

Pradana, S. 2018. 5 Kearifan Lokal di Indonesia Ini Bantu Kurangi Efek Global

Warming! Diakses pada 22 November 2018 pada https://www.idntimes.com/life/inspiration /shandypradana/5-kearifan-lokal-ini-bantu-kurangi-efek-globalwarming-c1c2/full

Remaja Kaisar Meiji dengan perwakilan asing di akhir Perang Boshin, 1868-

1870. Diakses pada 22 November 2018 pada http://en.wikipedia.org/wiki/Meiji_restoration

Restorasi Meiji. Diakses pada 22 November 2018 pada http://fataranaku.blogspot.com/2010/06/modernisasijepang-restorasi-meiji.html

Ritzer, G. 2007. Sosiologi Ilmu Pengetahuan Berparadigma Ganda. Jakarta:

Raja Grafindo Persada

Salim, A. 2001. Teori Dan Paradigma Penelitian Sosial: (Dari Denzin Guba dan Penerapannya). Yogyakarta: Tiara Wacana Yogya 
Siahaan, H. 1986. Pengantar Ke Arah Sejarah dan Teori Sosiologi. Jakarta: Erlangga

Sistem Sasi. Diakses pada 22 November 2018 pada

https://www.idntimes.com/life/inspiration/shandy-pradana /5kearifan-lokal-ini-bantu-kurangi-efek-global-warming-c1c2/full

Soekanto, S. 2013. Sosiologi Suatu Pengantar. Jakarta: Rajawali Pers

Tokugawa Ieyasu, Shogun pertama feodalisme korup dalam sejarah Jepang. Diakses pada 22 November 2018 pada

http://fataranaku.blogspot.com/2010/06/modernisasi-jepangrestorasi-meiji.html

Tradisi, spirit Bushido dan filosofi samurai yang tetap terjaga dari masa ke masa. Diakses pada 22 November 2018 pada http://samuraidave.wordpress.com/category/festival-of-ages/

Wagiran. 2012. Pengembangan Karakter Berbasis Kearifan Lokal Hamemayu Hayuning Bawana (Identifikasi Nilai-Nilai Karakter Berbasis Budaya) pada Jurnal Pendidikan Karakter, Tahun II, Nomor 3, Oktober 2012.

Wirawan. 2012. Teori-Teori Sosial dalam Tiga Paradigma. Jakarta:

Penadamedia Group. 


\title{
BERITA NEGARA REPUBLIK INDONESIA
}

\author{
No.1910, 2017 \\ KEMENSOS. Restorasi Sosial.

\section{NOMOR 22 TAHUN 2017 \\ TENTANG \\ RESTORASI SOSIAL} \\ PERATURAN MENTERI SOSIAL REPUBLIK INDONESIA \\ DENGAN RAHMAT TUHAN YANG MAHA ESA \\ MENTERI SOSIAL REPUBLIK INDONESIA,

\begin{abstract}
Menimbang : a. bahwa restorasi sosial merupakan implementasi dari memperbaiki dan memulihkan nilai-nilai luhur jati diri atau kepribadian bangsa Indonesia;

b. bahwa untuk mewujudkan masyarakat Indonesia yang hidup rukun, damai, bermoral, dan berbudaya, sehingga bangsa Indonesia mampu menjaga perbedaan dalam persatuan dan kesatuan, perlu penguatan restorasi sosial;

c. bahwa berdasarkan pertimbangan sebagaimana dimaksud dalam huruf a dan huruf b, perlu menetapkan Peraturan Menteri Sosial tentang Restorasi Sosial;
\end{abstract} \\ program Nawa Cita dan sebagai upaya untuk
}

Mengingat : 1. Undang-Undang Nomor 11 Tahun 2009 tentang Kesejahteraan Sosial (Lembaran Negara Republik Indonesia Tahun 2009 Nomor 12, Tambahan Lembaran Negara Republik Indonesia Nomor 4967); 
2. Peraturan Pemerintah Nomor 39 Tahun 2012 tentang Penyelenggaraan Kesejahteraan Sosial (Lembaran Negara Republik Indonesia Tahun 2012 Nomor 68, Tambahan Lembaran Negara Republik Indonesia Nomor 5294;

3. Peraturan Presiden Nomor 2 Tahun 2015 tentang Rencana Pembangunan Jangka Menengah Nasional Tahun 2015-2019 (Lembaran Negara Republik Indonesia Tahun 2015 Nomor 3);

4. Peraturan Presiden Nomor 46 Tahun 2015 tentang Kementerian Sosial (Lembaran Negara Republik Indonesia Tahun 2015 Nomor 86);

5. Peraturan Presiden Nomor 7 Tahun 2015 tentang Organisasi Kementerian Negara (Lembaran Negara Republik Indonesia Tahun 2015 Nomor 8);

6. Peraturan Menteri Sosial Nomor 20 Tahun 2015 tentang Organisasi dan Tata Kerja Kementerian Sosial (Berita Negara Republik Indonesia Tahun 2015 Nomor 1845) sebagaimana telah diubah dengan Peraturan Menteri Sosial Nomor 14 Tahun 2017 tentang Perubahan atas Peraturan Menteri Sosial Nomor 20 Tahun 2015 tentang Organisasi dan Tata Kerja Kementerian Sosial (Berita Negara Republik Indonesia Tahun 2017 Nomor 1125);

\section{MEMUTUSKAN:}

Menetapkan : PERATURAN MENTERI SOSIAL TENTANG RESTORASI SOSIAL.

BAB I

\section{KETENTUAN UMUM}

Pasal 1

Dalam Peraturan Menteri ini yang dimaksud dengan:

1. Restorasi Sosial adalah upaya yang diarahkan untuk mengembalikan atau memulihkan kondisi sosial masyarakat yang mengalami kondisi memudarnya/ melemahnya nilai-nilai luhur jati diri/kepribadian bangsa sehingga dapat kembali pada kondisi idealnya. 
2. Penyelenggaraan Kesejahteraan Sosial adalah upaya yang terarah, terpadu, dan berkelanjutan yang dilakukan Pemerintah, pemerintah daerah, dan masyarakat dalam bentuk pelayanan sosial guna memenuhi kebutuhan dasar setiap warga negara, yang meliputi rehabilitasi sosial, jaminan sosial, pemberdayaan sosial, dan perlindungan sosial.

3. Menteri adalah menteri yang menyelenggarakan urusan di bidang sosial.

\title{
Pasal 2
}

(1) Restorasi Sosial dimaksudkan untuk meletakkan Pancasila pada fungsi dan peranannya sebagai dasar filsafat negara, membebaskannya dari stigma, serta diberi ruang pemaknaan yang cukup, untuk merespon tantangan perubahan zaman.

(2) Restorasi Sosial bertujuan untuk mengembalikan atau memulihkan nilai-nilai luhur jati diri atau kepribadian bangsa yang memudar atau melemah sehingga dapat kembali sesuai dengan yang dicita-citakan sebagaimana tercantum dalam pembukaan Undang-Undang Dasar 1945.

\author{
BAB II \\ PELAKSANAAN \\ Bagian Kesatu \\ Umum
}

Pasal 3

Restorasi Sosial dilakukan dengan memberikan penguatan pada masyarakat guna menumbuhkan kembali nilai-nilai luhur budaya bangsa Indonesia. 
Pasal 4

Sasaran penguatan Restorasi Sosial diperuntukkan kepada:

a. masyarakat; dan

b. nilai-nilai kearifan lokal yang sudah memudar atau menurun.

\section{Bagian Kedua \\ Strategi}

Pasal 5

(1) Restorasi Sosial dilakukan melalui strategi penguatan Restorasi Sosial.

(2) Strategi penguatan Restorasi Sosial sebagaimana dimaksud pada ayat (1) dilakukan dengan cara:
a. memperkuat pendidikan kebhinekaan dan menciptakan ruang dialog antarwarga;
b. membangun kembali modal sosial untuk memperkukuh karakter dan jati diri bangsa;
c. meningkatkan peran kelembagaan sosial;
d. meningkatkan partisipasi pemuda dalam pembangunan; dan
e. meningkatkan pembudayaan kesetiakawananan sosial dalam Penyelenggaraan Kesejahteraan Sosial.

Pasal 6

Memperkuat pendidikan kebhinekaan dan menciptakan ruang dialog antarwarga sebagaimana dimaksud dalam Pasal 5 ayat

(2) huruf a dilakukan melalui:

a. pendidikan karakter dan budi pekerti bangsa yang dilandasi oleh nilai-nilai kearifan lokal;

b. peningkatan pemahaman generasi muda melalui nilainilai kesejarahan dan wawasan kebangsaan; dan

c. pelindungan, pengembangan, serta aktualisasi nilai dan tradisi masyarakat untuk memperkaya dan memperkukuh khazanah budaya bangsa. 


\section{Pasal 7}

Membangun kembali modal sosial untuk memperkukuh karakter dan jati diri bangsa sebagaimana dimaksud dalam Pasal 5 ayat (2) huruf b dilakukan melalui:

a. pengembangan kepedulian sosial;

b. pengembangan pranata gotong royong;

c. penggalangan inisiatif komunitas untuk merencanakan dan ikut menyediakan kebutuhan komunitas mereka sendiri;

d. pemberdayaan masyarakat adat dan komunitas budaya;

e. pengembangan karakter dan jati diri bangsa; dan

f. peningkatan kepercayaan antarwarga dan pencegahan diskriminasi.

\section{Pasal 8}

Meningkatkan peran kelembagaan sosial sebagaimana dimaksud dalam Pasal 5 ayat (2) huruf $\mathrm{c}$ dilakukan melalui:

a. pengembangan sistem rujukan dan layanan terpadu di tingkat daerah kabupaten/kota;

b. pengembangan kompetensi dan kertersediaan tenaga kesejahteraan sosial; dan

c. peningkatan kualitas dan standardisasi lembaga kesejahteraan sosial sebagai agen kesetiakawanan sosial.

Pasal 9

Meningkatkan partisipasi pemuda dalam pembangunan sebagaimana dimaksud dalam Pasal 5 ayat (2) huruf d dilakukan melalui:

a. perluasan memperoleh pendidikan dan keterampilan;

b. peningkatan peran serta pemuda dalam pembangunan sosial, politik, ekonomi, budaya, dan agama;

c. peningkatan potensi pemuda dalam kewirausahaan, kepeloporan, dan kepemimpinan dalam pembangunan; dan

d. pelindungan generasi muda terhadap bahaya penyalahgunaan Narkotika, Psikotropika, dan Zat Adiktif Lainnya, minuman keras, penyebaran penyakit Human 
Immunodeficiency Virus dan Acquired Immune Deficiency Syndrome, serta penyakit menular seksual di kalangan pemuda.

Pasal 10

Meningkatkan pembudayaan kesetiakawanan sosial dalam Penyelenggaraan Kesejahteraan Sosial sebagaimana dimaksud dalam Pasal 5 ayat (2) huruf e dilakukan melalui:

a. peningkatan penyuluhan sosial;

b. penguatan peran Pemerintah Pusat, pemerintan daerah, dan masyarakat dalam penyelenggaraan kesetiakawanan sosial; dan

c. peningkatan jejaring kerja kesetiakawanan sosial.

\section{Bagian Ketiga}

Penguatan Restorasi Sosial

\section{Pasal 11}

Penguatan Restorasi Sosial dilaksanakan secara mandiri dan terintegrasi di mulai dari tingkat desa/kelurahan/nama lain sampai dengan tingkat nasional.

\section{Pasal 12}

(1) Penguatan Restorasi Sosial dilakukan oleh Pemerintah Pusat, pemerintah daerah, dan masyarakat.

(2) Penguatan Restorasi Sosial sebagaimana dimaksud pada ayat (1) dilaksanakan secara terencana, terarah, terpadu, berkelanjutan, dan terkoordinasi.

(3) Penguatan Restorasi Sosial yang dilakukan oleh Pemerintah Pusat, pemerintah daerah, dan masyarakat dilakukan dengan kegiatan tahapan:
a. memetakan dan mengidentifikasi nilai-nilai kearifan lokal;
b. pelaksanaan penjajagan;
c. seleksi dan identifikasi;
d. menetapkan kesepakatan bersama;
e. menyusun rencana kerja; 
f. mengorganisasikan, mengoordinasikan, dan melaksanakan penguatan; dan

g. menyampaikan laporan.

\section{Pasal 13}

(1) Penguatan Restorasi Sosial oleh masyarakat sebagaimana dimaksud dalam Pasal 12 ayat (1) meliputi:
a. keluarga;
b. badan usaha;
c. lembaga pendidikan;
d. organisasi masyarakat;
e. kelompok komunitas;
f. kelompok profesi; dan
g. media masa.

(2) Penguatan Restorasi Sosial yang dilaksanakan oleh masyarakat sebagaimana dimaksud pada ayat (1) mengacu pada kebijakan Pemerintah Pusat dan pemerintah daerah.

\section{Pasal 14}

Penguatan Restorasi Sosial dilakukan dengan cara:

a. kampanye Restorasi Sosial;

b. jejaring kerja Restorasi Sosial;

c. bengkel karakter; dan

d. aksi sosial.

\section{Pasal 15}

(1) Kampanye Restorasi Sosial sebagaimana dimaksud dalam Pasal 14 huruf a merupakan perwujudan persemaian budaya untuk penguatan Restorasi Sosial yang dilakukan secara terencana, terarah, terpadu, berkelanjutan, dan terkoordinasi.

(2) Kampanye Restorasi Sosial sebagaimana dimaksud pada ayat (1) berupa:
a. sosialisasi;
b. diseminasi;
c. penataran; 

d. lokakarya;
e. seminar; atau
f. forum diskusi.

\section{Pasal 16}

(1) Jejaring kerja Restorasi Sosial sebagaimana dimaksud dalam Pasal 14 huruf b merupakan upaya membangun ikatan kerja dan kemitraan antarkelompok serta berbagai lembaga yang dapat memberikan kontribusi dalam mendukung kegiatan Restorasi Sosial.

(2) Jejaring kerja Restorasi Sosial sebagaimana dimaksud pada ayat (1) dilakukan dengan cara:
a. menciptakan ruang dialog antara pemangku kepentingan;
b. mengedepankan adanya kesamaan sudut pandang, tujuan, dan rasa; dan
c. membuat komitmen untuk bekerja bersama dan saling bantu dalam suasana yang toleran.

\section{Pasal 17}

(1) Bengkel karakter sebagaimana dimaksud dalam Pasal 14 huruf c merupakan kegiatan penyampaian informasi mengenai materi Restorasi Sosial, pembinaan, dan pembentukan karakter berjiwa sosial bagi generasi muda yang dilakukan secara terstruktur dan berkelanjutan.

(2) Bengkel karakter sebagaimana dimaksud pada ayat (1) dilakukan melalui:
a. bimbingan teknis;
b. pendidikan karakter; dan/atau
c. penyuluhan.

Pasal 18

(1) Aksi sosial sebagaimana dimaksud dalam Pasal 14 huruf d merupakan tindakan sosial yang dilakukan secara terencana, terarah, terpadu, berkelanjutan, dan terkoordinasi untuk merestorasi kehidupan sosial masyarakat. 
(2) Aksi sosial sebagaimana dimaksud pada ayat (1) dilaksanakan dengan cara:
a. memperingati hari besar nasional;
b. gerakan masyarakat peduli dan berbagi; dan/atau
c. bakti sosial.

\section{Pasal 19}

Ketentuan lebih lanjut mengenai kampanye Restorasi Sosial sebagaimana dimaksud dalam Pasal 15, jejaring kerja Restorasi Sosial sebagaimana dimaksud dalam Pasal 16, bengkel karakter sebagaimana dimaksud dalam Pasal 17, dan aksi sosial sebagaimana dimaksud dalam Pasal 18 diatur dengan Peraturan Direktur Jenderal Pemberdayaan Sosial.

\section{BAB III \\ PENDANAAN}

Pasal 20

Sumber pendanaan penguatan Restorasi Sosial dapat berasal dari:

a. Anggaran Pendapatan dan Belanja Negara;

b. anggaran pendapatan dan belanja daerah; dan/atau

c. sumber pendanaan yang sah dan tidak mengikat sesuai dengan ketentuan peraturan perundang-undangan.

\section{BAB IV}

\section{PEMANTAUAN DAN EVALUASI}

\section{Pasal 21}

(1) Menteri, gubernur, dan bupati/wali kota sesuai dengan kewenangannya melakukan pemantauan untuk menjamin sinergi, kesinambungan, dan efektivitas langkah-langkah secara terpadu dalam pelaksanaan kebijakan, program, dan kegiatan penguatan Restorasi Sosial.

(2) Pemantauan sebagaimana dimaksud pada ayat (1) dilakukan secara berkala melalui koordinasi dan 
pemantauan langsung terhadap penguatan Restorasi Sosial.

\section{Pasal 22}

(1) Menteri, gubernur, dan bupati/wali kota sesuai dengan kewenangannya melakukan evaluasi pelaksanaan kebijakan, program, dan kegiatan yang dilakukan pada akhir tahun anggaran.

(2) Hasil evaluasi pelaksanaan kebijakan, program, dan kegiatan penguatan Restorasi Sosial sebagaimana dimaksud pada ayat (1) digunakan untuk perencanaan tahun berikutnya untuk perbaikan program.

(3) Evaluasi sebagaimana dimaksud pada ayat (1) dilaksanakan sesuai dengan ketentuan peraturan perundang-undangan.

\section{BAB V \\ PELAPORAN}

Pasal 23

Menteri, gubernur, dan bupati/wali kota wajib membuat laporan tertulis secara berjenjang mengenai penguatan Restorasi Sosial sesuai dengan kewenangannya.

Pasal 24

(1) Laporan penguatan Restorasi Sosial sebagaimana dimaksud dalam Pasal 23 dilakukan setiap tahun.

(2) Bentuk dan tata cara laporan sebagaimana dimaksud pada ayat (1) dilaksanakan sesuai dengan ketentuan peraturan perundang-undangan. 


\section{BAB VI}

\section{PEMBINAAN DAN PENGAWASAN}

\section{Pasal 25}

(1) Menteri melakukan pembinaan dan pengawasan atas pelaksanaan kebijakan, program, dan kegiatan penguatan Restorasi Sosial di daerah provinsi.

(2) Gubernur melakukan pembinaan dan pengawasan atas pelaksanaan kebijakan, program, dan kegiatan penguatan Restorasi Sosial di daerah kabupaten/kota.

(3) Bupati/wali kota melakukan pembinaan dan pengawasan atas pelaksanaan kegiatan penguatan Restorasi Sosial di kecamatan.

\section{Pasal 26}

Masyarakat dapat melakukan pengawasan terhadap penguatan Restorasi Sosial sesuai dengan mekanisme dan ketentuan peraturan perundang-undangan.

\section{BAB VII}

\section{KETENTUAN PENUTUP}

\section{Pasal 27}

Peraturan Menteri ini mulai berlaku pada tanggal diundangkan. 
Agar setiap orang mengetahuinya, memerintahkan pengundangan Peraturan Menteri ini dengan penempatannya dalam Berita Negara Republik Indonesia.

\section{Ditetapkan di Jakarta}

pada tanggal 28 November 2017

MENTERI SOSIAL REPUBLIK INDONESIA,

$\mathrm{ttd}$

\section{KHOFIFAH INDAR PARAWANSA}

Diundangkan di Jakarta

pada tanggal 28 Desember 2017

DIREK'TUR JENDERAL

PERATURAN PERUNDANG-UNDANGAN

KEMENTERIAN HUKUM DAN HAK ASASI MANUSIA

REPUBLIK INDONESIA,

ttd

WIDODO EKATJAHJANA 


\section{RIWAYAT HIDUP}

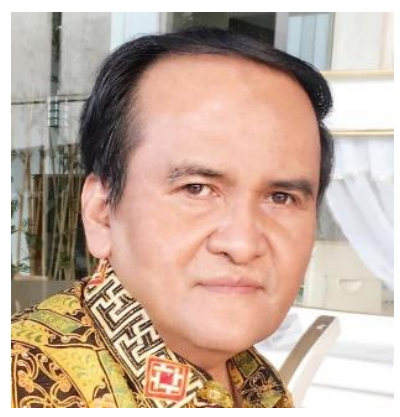

Dr. Haswan Yunaz MM, MSi, lahir pada tanggal 3 Oktober 1960 di Payakumbuh Sumatera Barat. Menyelesaikan pendidikan dasar pada tahun 1973 di SDN 4 Teladan Payakumbuh dan melanjutkan pendidikan Sekolah Teknik Negeri Payakumbuh pada tahun 1976. Pada tahun 1979, penulis menamatkan pendidikan pada Sekolah Teknik Menengah Negeri Payakumbuh dan melanjutkan pendidikan pada Akademi Pimpinan Perusahaan Departemen Perindustrian RI tahun 1984. Penulis kemudian melanjutkan jenjang pendidikan S1 Ekonomi pada Universitas Krisnadwipayana Jakarta tahun 1987. Gelar Magister Manajemen pada jenjang strata dua S2 diperoleh tahun 1997 pada Universitas Indonusa Esa Unggul dan Gelar Magister Sains Ilmu Lingkungan diperoleh tahun 2001 pada Universitas Indonesia. Gelar Doktor Ilmu Lingkungan diperoleh tahun 2007 di Universitas Indonesia Jakarta

Riwayat pekerjaan yang pernah dijalankan penulis adalah Calon Pengawai Negeri Sipil sebagai di Kopertis Wilayah 3 Jakarta tahun 1992. Tahun 1994 diangkat sebagai Pegawai Negeri Sipil sekaligus Staf Khusus Menteri Negara Pemuda dan Olahraga pada tahun 1993-1995. Pada tahun 1998-2001 penulis berkesempatan untuk menjadi Sekretaris Pelaksanaan Kerjasama Komite Pemuda ASEAN (Focal Point ASEAN Sub Committee on Youth). Pernah menjabat Asisten Deputi Bidang Lingkungan Hidup Menko Kesra tahun 2005 dan kemudian diangkat menjadi Kepala Biro Perencanaan dan Kerjasama Luar Negeri di instansi yang sama. Tahun 2012 diangkat menjadi Staf Ahli Menko Kesra Bidang Pembangunan Daerah Tertinggal dan kemudian di tahun 2012 juga diangkat menjadi Deputi Menko Kesra Bidang Kebudayaan pada Kabinet Indonesia Bersatu dan dilanjutkan sampai Kabinet Kerja hingga tahun 2016. Tahun 2016 diangkat menjadi Staf Ahli Menko Pembangunan Manusia dan Kebudayaan Bidang Multikuturalismen Restorasi Sosial dan Jatidiri Bangsa.

Pendidikan dan Latihan yang pernah diikuti oleh penulis adalah mengikuti Penataran Administrasi Pendidikan di Depdiknas tahun 1990. Pada tahun 1996 pernah mengikuti Kursus Singkat LEMHANAS serta Pendidikan dan Latihan Administrasi Umum/ADUM tahun 1997 di Sekretariat Negara Republik Indonesia Jakarta dan berhasil menjadi lulusan 5 besar terbaik. Training for Trainer program kuliah kerja usaha Depdiknas Jakarta tahun 1997 dan tahun yang sama mengikuti Training Strategi Pengembangan Produktivitas Sumber Daya Manusia Menghadapi Era Globalisasi di Jakarta. Tahun 1997 juga mengikuti Workshop on Youth Tourism for Young Leader Asia and Pasific di Bangkok. Pendidikan dan Latihan SPAMA diikuti tahun 1997 di Sekretariat Negara Republik Indonesia Jakarta dan berhasil menjadi lulusan 5 terbaik. Kursus Analisis AMDAL A di Universitas Indonesia tahun 2001 dan 
Tahun 2009 mengikuti Diklatpim II di LAN RI serta mengikuti training penyusunan Standart Operating Procedure Tahun 2010.

Berbagai Pengalaman Kedinasan dalam Negeri dan luar negeri yang pernah diikuti antara lain Menjadi Tim Kemanusiaan Indonesia untuk Membantu Korban Gempa Bumi Philipina dan di BAM Iran tahun 2003 dan dan Tim Kemanusiaan Indonesia untuk Membantu Korban Gempa Bumi di Philipina tahun 2007 dan Tim Bantuan Kemanusiaan Indonesia untuk Korban Badai Nargis Myanmar yang terjadi 3 Mei 2008. Peserta Senior Officials Committee for the ASCC meeting di Kuala Lumpur tahun 2009. Beberapa karya tulis juga telah dihasilkan antara lain: Penulis Pidato Menpora pada 1993-1995, penulis buku Pemuda Pembangunan dan Masa Depan1995, penulis buku Upaya dan Langkah Pemerintah dalam Penyelesaian Konflik di Ambon dan Poso 2003. Buku Peran Indonesia Membangun Pilar Sosial Budaya ASEAN tahun 2011. Buku Percepatan Pembangunan Papua dan Papua Barat tahun 2012. Berbagai karya tulis yang dihasilkan tahun 2016 antara lain Revolusi Mental sebagai Prasyarat Indonesia Maju dan Modern, Konsepsi Kebudayaan Nasional, Bonus Demografi sebagai Modal Dasar Percepatan Pembangunan Indonesia, Pencegahan Penyalahgunaan dan Peredaran Gelap Narkoba Melalui Pendekatan Sosial Budaya. Beberapa kegiatan luar negeri yang pernah diikuti delegasi Pemuda Indonesia ke Arab Saudi tanggal 9 s/d 19 September 1991, peserta Dialog Pemuda Malaysia dan Indonesia (Malindo) III di Kucing Serawak Malaysia, peserta Dialog Pemuda Indonesia dan Singapura tanggal 20 s/d 23 Juni 1993 di Jakarta, peserta Work Shop on Youth Tourism di Bangkok, peserta environmental youth camp di Philipina 1997, pembicara pada seminar internasional kepemudaan di Taiwan 1995, pertemuan pemuda di Amstrerdam 1996, Peserta Sidang Umum UNESCO tahun 2012 di Paris, Peserta Sidang Umum Badan Pangan Dunia/FAO di Roma Italia tahun 2012, Ketua Delegasi Indonesia pada Pertemuan dengan Kementerian Pertahanan Australia dalam rangka Mengundang Veteran Perang Dunia Kedua Menghadiri Sail Morotai tahun 2013. Participants of The Fifth Session of The General Assembly, UNESCO Paris June 2014. Ketua Delegasi Pertemuan dengan Daegu University Busan dan Kaya University, Gimhae serta Hankok University Seoul Korea Selatan tahun 2016. Beberapa Satya Lencana juga sudah diterima dari Presiden Republik Indonesia antara lain Satyalncana Karya Satya X Tahun 2002 dan Satyalancana Wirakarya Tahun 2011 serta Satyalncana Karya Satya XX tahun 2017.

Hormat Penulis 


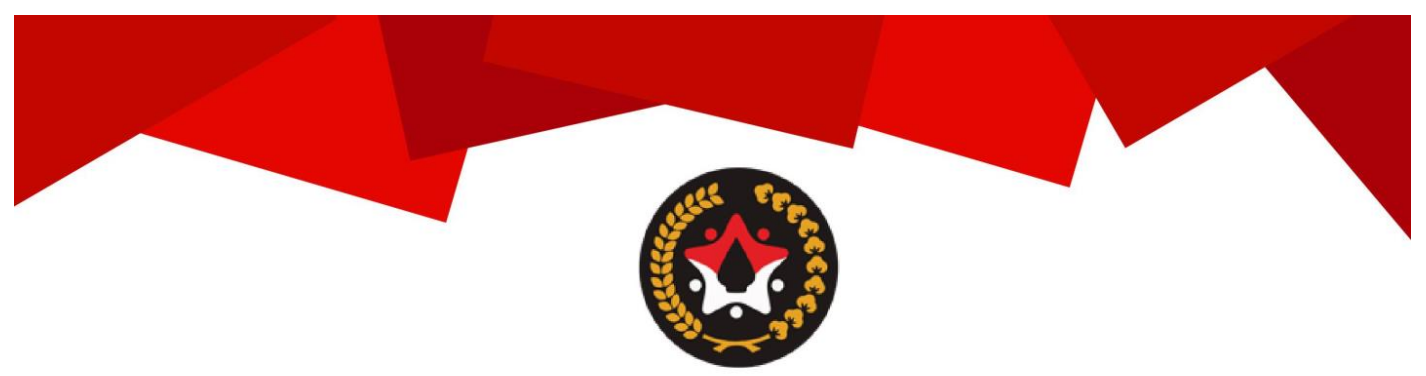

KEMENTERIAN KOORDINATOR

BIDANG PEMBANGUNAN MANUSIA DAN KEBUDAYAAN REPUBLIK INDONESIA

\section{RESTORASI SOSIAL} Untuk Indonesia Maju dan Bermartabat

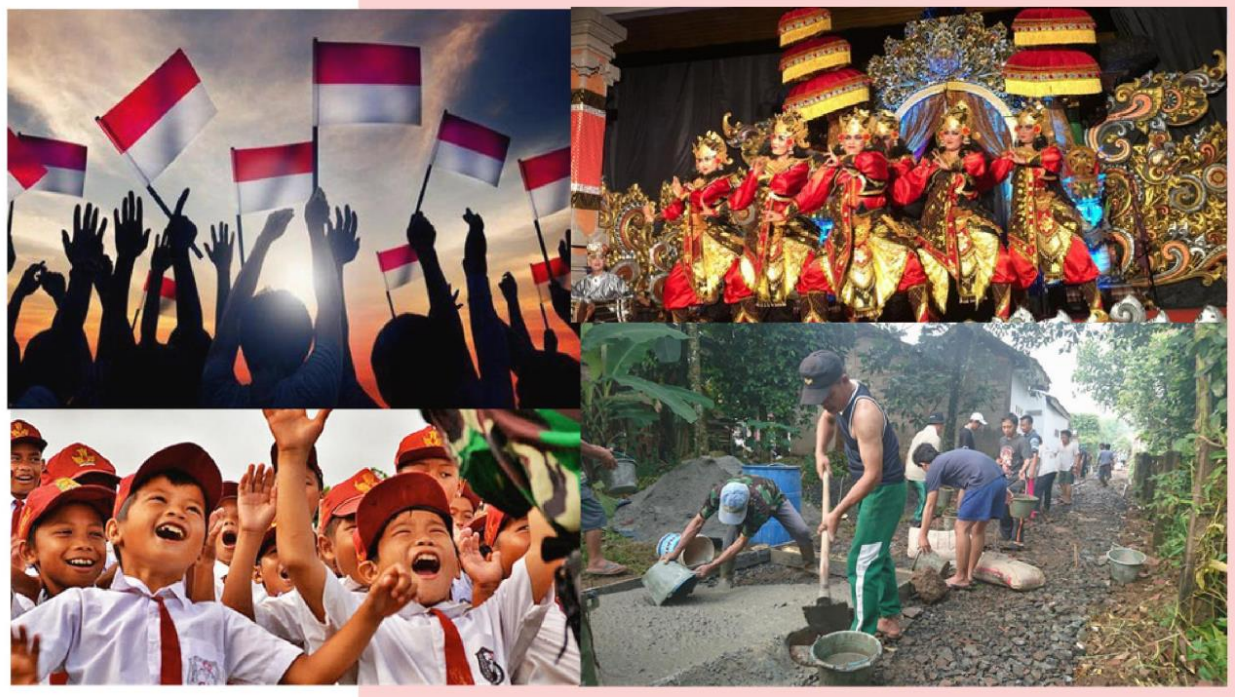

\section{Haswan Yunaz}

